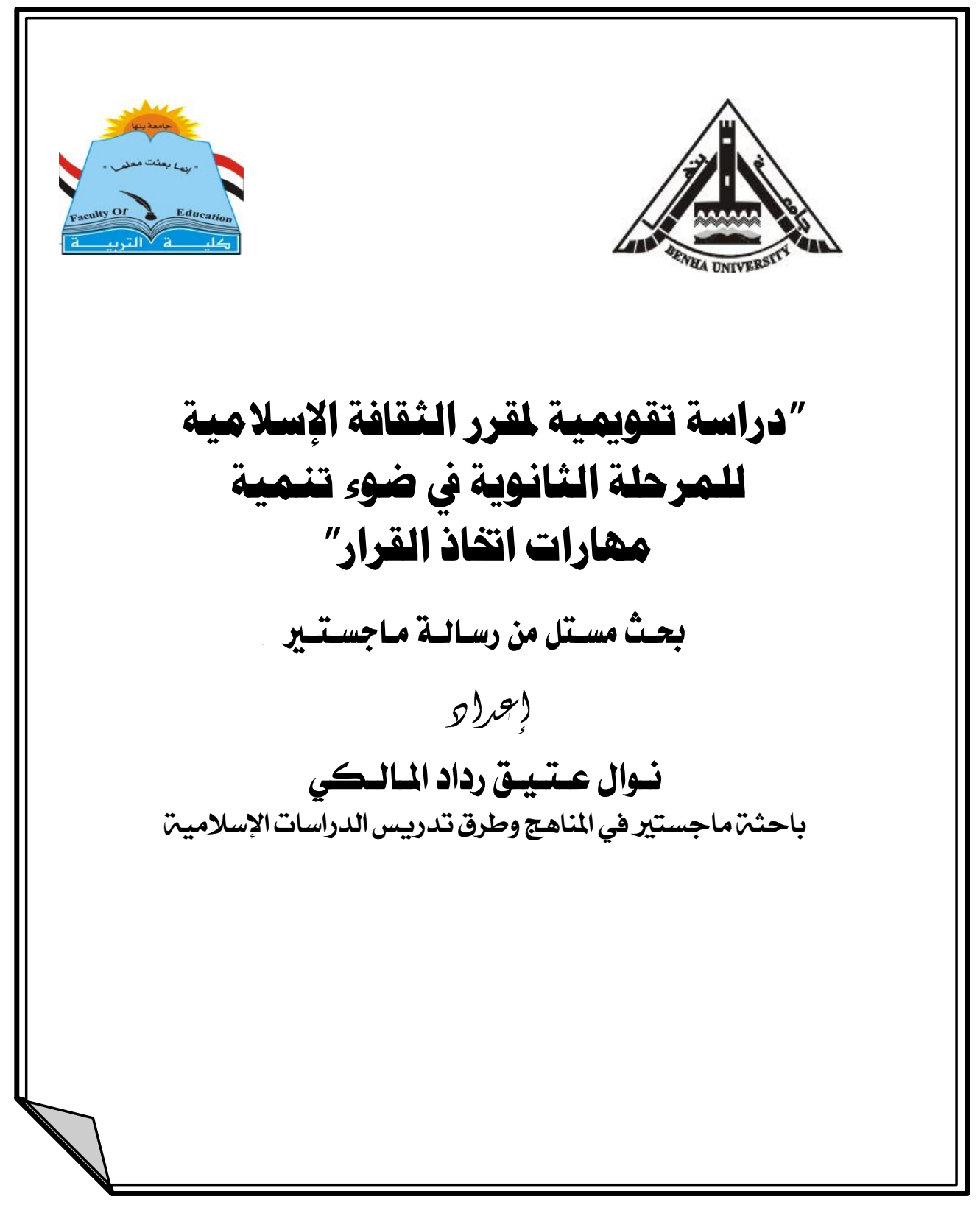




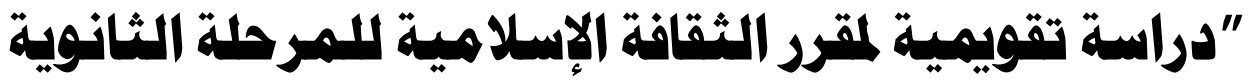

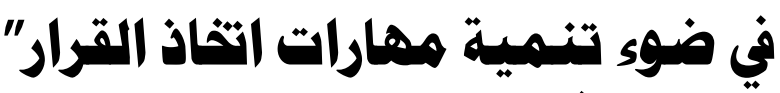

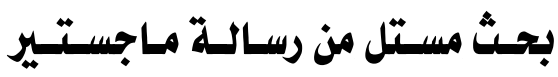

$$
\text { D) (9) }
$$

\section{دا نـوال عستيـق رداد المالـكي \\ باحثتماجستير في المناهج وطرق تدريس الدراسات الإسلاميت}

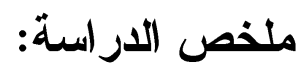

هدفت الدراسة إلى الكشف عن درجة تضمين مقرر الثقافة الإسلامية للمرحلة الثانوية

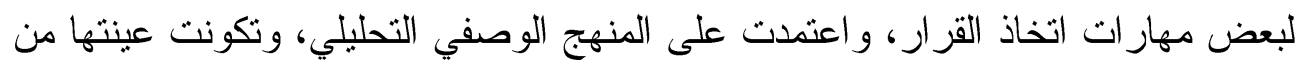

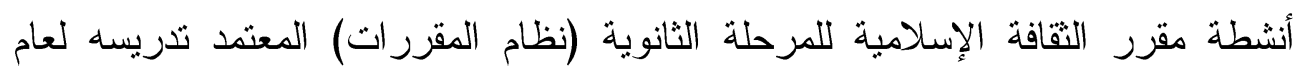

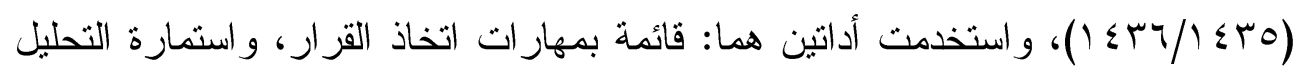

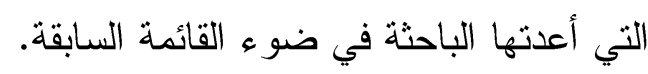
وبعد التأكد من ثبات وصدق الأدادئن فئنة واستخدام المعالجة الإحصائية، واستخدام

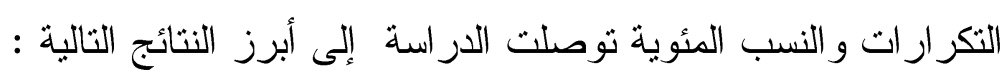

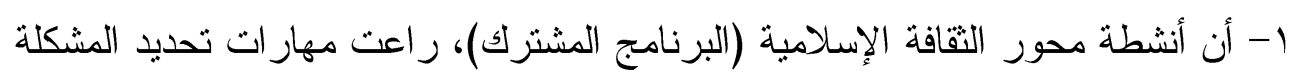

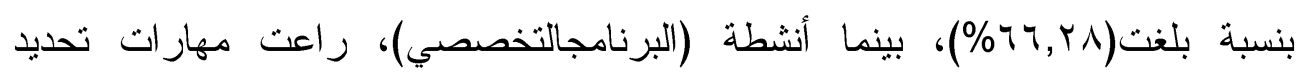

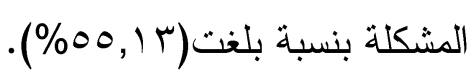

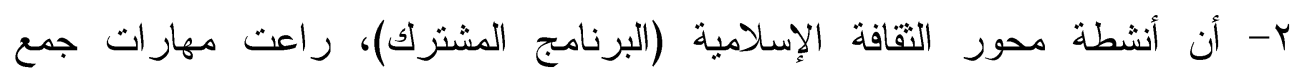

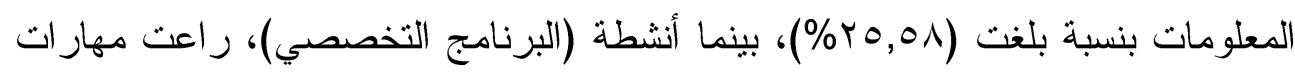

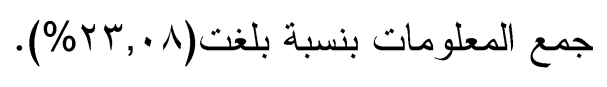


r- أن أنشطة محور الثقافة الإسلامية (البرنامج المشترك)، راعت مهارات تحديد البدائل

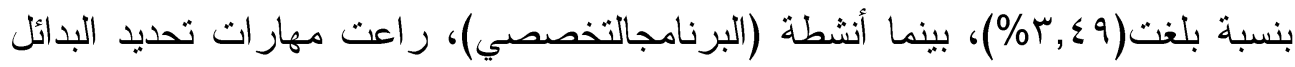

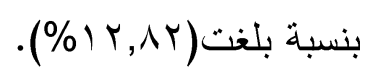

ع- أن أنشطة محور الثقافة الإسلامية (البرنامج المشترك )، راعت مهارات اختيار

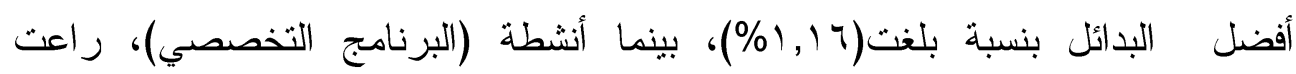

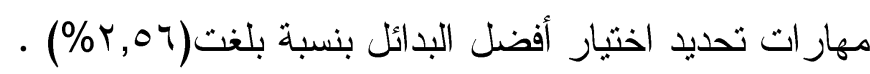

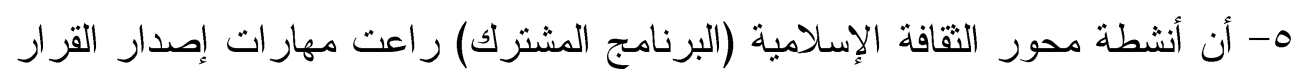

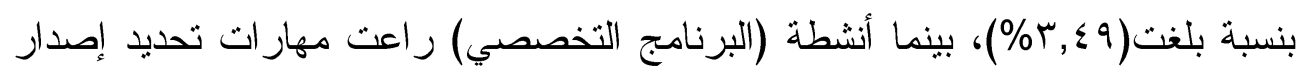

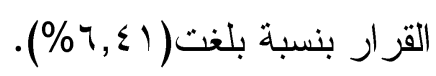

وفي ضوء النتائج أوصت الدراسة بعدة توصيات كان من أبرزها ضرورة تطوير

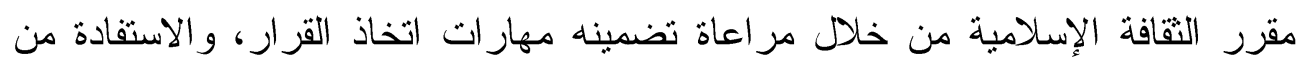
التصور المقترح عند تطوير مقرر الثقافة الإسلامية للمرحلة الثانوية (نظام المقررات) لمعالجة القصور في المقرر الحالي. الكلمات المفتاحية: مهار ات اتخاذ القزار، الثقافة الإسلامية.

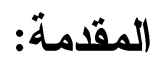

يتميز عصرنا الحالي بالتطور ات المتلاحقة، والتغيرات السريعة في شتى المجالات، وخاصة في مجال العلم والتكنولوجيا، فقد أصبح العصر خلالها يعيش ثورة هائلة من المعلومات و المعرفة، مما أدى إلى زيادة المشكلات وتشابكها، وتعدد البدائل، وأصبح

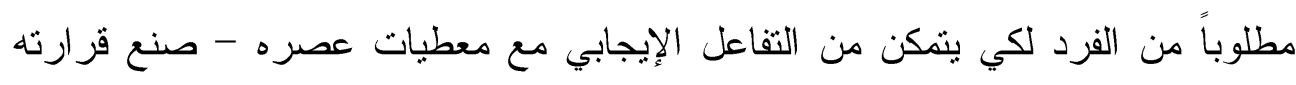
بحكمة.

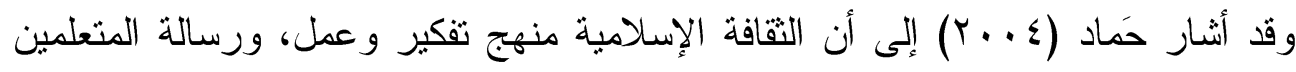
في الحياة الدنيا، وأداة بناء الثخصية الإسلامية، و الوسيلة الرئيسة لإكساب المتعلم

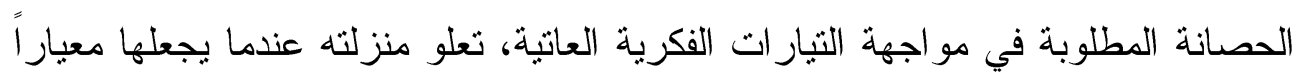


أساسياً في شؤون حياته سلوكًا، وفكرًا، و اعتقادًا، وتتحدر مكانته عندما يجعلها معيارً ثانوياً إلى جانب معايير أخرى لا تنبثق من الإسلام.

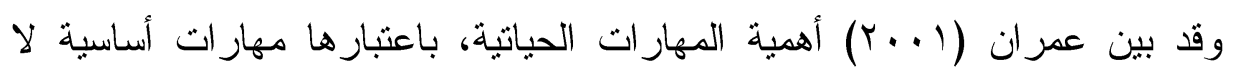
غنى للطالب عنها، ليس فقط لإشباع حاجاته الأساسية من أجل البقاء، ولكن من أجل استمر ار التقدم، وتطوير أساليب معايشته في مو اقف الحياة اليومية. وقد أشار بعض المتخصصين في المناهج إلى أن الاهنمام بتعليم المهارات الحياتية من أهم الاتجاهات الحديثة في المجال التربوي، وقد أزداد الاهنمام في السنوات الأخيرة بضرورة دمج المهارات الحياتية في مناهج التربية الإسلامية لإعداد الطالب إعداداً شاملاً

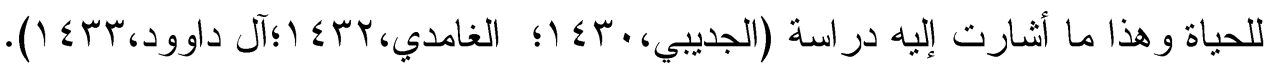
وتعتبر عملية اتخاذ القرار إحدى المهارات الحياتية التي يمارسها الفرد بصفة شبة دهة دائمة في الحياة اليومية، وهو أمر يتطلب من الفرد أن يكون على وعي بنتائج القرارات

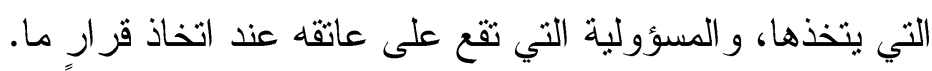
ونجد الكثير من الآيات القر آنية و المو اقف العديدةفي حياة الرسول- صلى الفه الله عليه

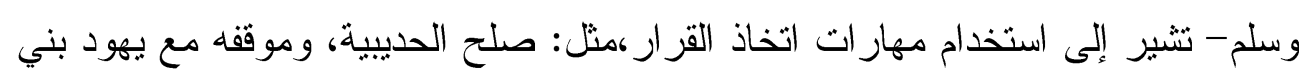
القينقاع، وحفر الخندق.... و غيرها.

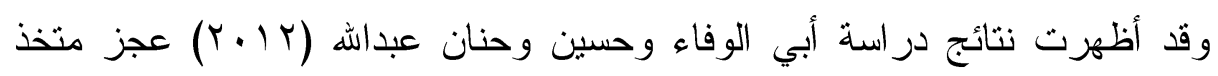

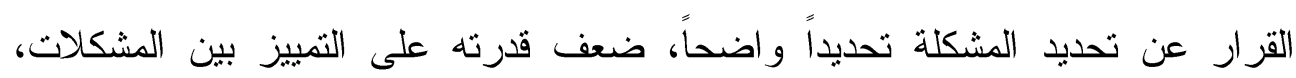

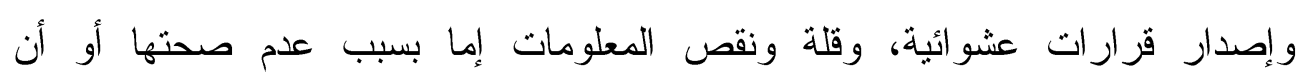
المعلومات المتعلقة بالبدائل غير كافية، كما أوصت بضرورة أنباع أسلوب حل المشكلات عند عملية صنع القرار ومن ثم التزكيز على تحديد المشكلة والبحث عن بدائل وتقييمها و اختيار البديل المناسب لحل المشكلة.

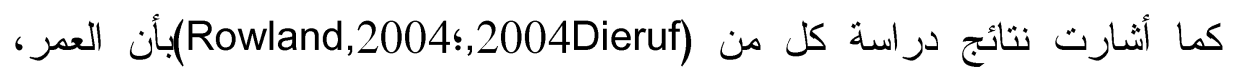
و السمات الثخصية، والبيئة التعليمية له تأثير كبير في عملية اتخاذ القرار، وأوصت

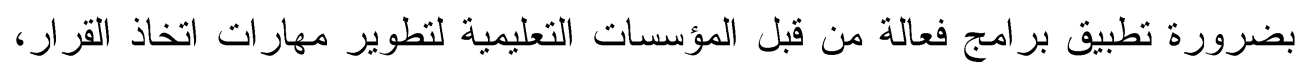
وتحفيز الطلاب على المشاركة، وتتمية هذه المهار ات لديهر لمو اجهة التحديات. 
لهذا ينبغي أن تكون مناهج الثقافة الإسلامية مرتبطة باحتباجات الطلبة، لتقوية شعور هم بمشكلاتهم، وقضايا مجتمعهم والإسهام في حلها، وهذا ما أوصت به دراسة

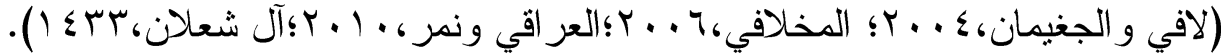
ولهذا ينبغي أن يسعى القائمون إلى تقويم وتطوير عناصر منظومة المنهج، بحيث تكون أهدافها، و أساليبها، و أنشطنها تحث على تربية العقل، وتتمية مهار ات التقكير ـ لهذا جاءت الدر اسة الحالية لتبحث عن درجة تضمين مقررات الثقافة الإسلامية لمهار ات اتخاذ

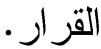

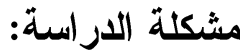
من خلال خبرة الباحثة وملاحظتها ما يجري في الو اقع الاجتماعي، من الحيرة و الثزدد لاى طلاب/طالبات المرحلة الثانوية في اتخاذ القرار المناسب. وملاحظتها ما يجري في الو اقع التعليميعن تتميةالمهار ات الحياثية، فقد أصبحت المهارات الحياتية أمراً مهواً، ومحور اً أساسياً لأساليب تدريس المناهج في المؤسسات التربوية.

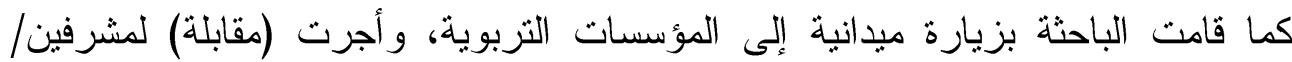
مشرفات التزبية الإسلامبة للمرحلة الثانوية؛ بهدف الكشف عن درجة امتلاك معلمي/معلمات الثربية الإسلامية، وممارستهم لمهار ات اتخاذ داخل الحجرة الدر اسية، وقد تبين تدني امتلاك معلمي/معلمات الثربية الإسلامية لمهار ات اتخاذ القرار. وإضافة لذلك ثقويم أنشطة محور الثقافة الإسلامية للمرحلة الثانوية( نظام المقررات) تأتي الإنياتيه استجابة لخطة الثطوير، ومتفقة مع مشروع الملك عبداله بن عبد العزيز آل سعود، للنطوير المناهج، خصوصاً بعد إفر اد لمدارس نظام المقررات كتب مستقله، مما يعطي أهمية إضافية لتقويمها.

ومن خلال البحث والاطلاع على الدراسات السابقة و البحوث، كدراسة (آل

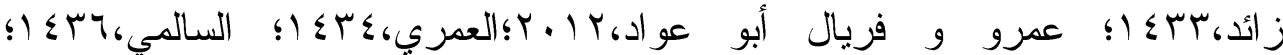
الجعيد، جبـ (؛) و التي أكدت على ضرورة إجر اء مزيد من الدراسات التقويمية و التحليلية لأنشطة كتبالتربية الإسلامية، اتضح أنه لا يوجد دراسات تتاولت تتمية مهارات اتخاذ القرار في مقررات التربية الإسلامية، و استجابة لتوصيات الدراسات سابقة، ظهرت 
المشكلة لدى الباحثة، وشعرت بضرورة إجر اء هذه الدر اسةللبحثعنمىتضمينمقرر الثقافة الإسلامية للمرحلة الثانوية في ضوء تتمية مهار ات اتخاذ القرار. أسئلة الار اسة:

تحددت مشكلة الدراسة الحالية في الإجابة عن التساؤلات التالية:

س // ما مهار ات اتخاذ القرار اللازم تضمينها في مقرر الثقافة الإسلامية للمرحلة الثانوية؛؟

س ب/ما درجة تضمين مهار ات اتخاذ القرار في مقرر الثقافة الإسلامية للمرحلة الثانوية ؟

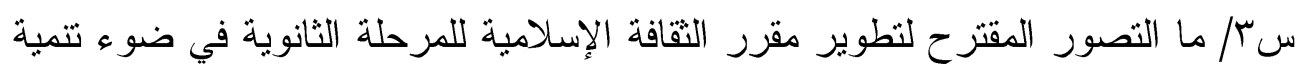

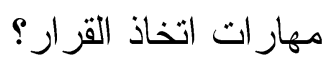
أهمية الدراسة : أنهار

1- بالنسبة لو اضعي المناهج وطر ائق التدريس، وذلك من خلال: أ- إعدادقائمة معايير في ضوء تتمية بعض مهار ات اتخاذ القرار، لتقويم أنشطة مقرر الثقافة الإسلامية في المرحلة الثانوية،يستعان بهافيناءأوتطوير هذه الأنشطة. ب-تقديم تصور مقترح بسترشد به عند تطوير أو بناء مقرر الثقافة الإسلامية للمرحلة الثانوية.

r - بالنسبة للمعلمين والمشرفين التربويين، وذلك من خلال: تعريف المعلمين و المشرفين ببعض مهار ات اتخاذ القزار، وتقديم نموذج تدريسي مقترح

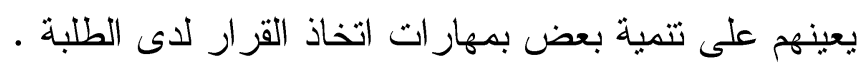

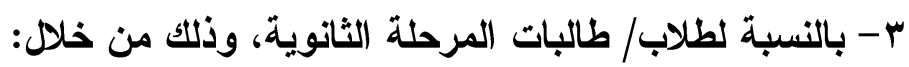
تأهيل وتخريج دارسين قادرين على حل المشكلات التي تو اجههم، و إتاحة الفرصة أمامهم لتتمية أفكار هم، وتتمبة بعض مهار ات اتخاذ القرار لديهم لممارستها في مو اقف عديدة .

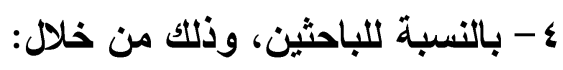

توجيه اهتمام الباحثين في مجال الثربية الإسلامية عامة، و الثقافة الإسلامية خاصة إلى هن

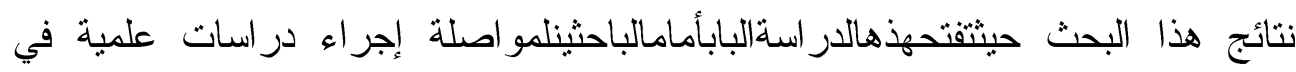
تتمبة مهار ات اتخاذ القرار. 
أهداف الاراسة:سعت هذه الدر اسة إلى تحقيق الأهداف الآتية: ا-التوصل لمهار ات اتخاذ القرار المناسبة لطلاب/طالبات المرحلة الثانوية واللازم تضمينها في مقرر الثقافة الإسلامية المقدمة لهم. r-الكشف عن مدى تضمين مقرر الثقافة الإسلامية للمرحلة الثانوية لمهارات اتخاذ القرار

مصطلحاث الدر اسةة: تحددت مصطلحات الدر اسة في الثالي: الثقافة الإسلامية: تعرّفها الباحثة بأنها : محور من محاور مقرر الحديث (1) و(r) و المعتمد تدريسه من وزارة التربية و التعليم في المملكة العربية السعودية للمرحلة الثانوية في مدارس نظام المقررات، ويهدف إلى بيان العقيدة الصحيحة للطلاب/الطالبات ووقوفهم على ثروة الإسلام الفكرية و الخلقية وتزجمة الأفكار و التعاليم الإسلامية إلى و اقع عملي.

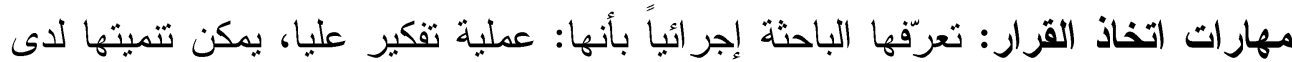
الطالب/الطالبة، وذلك من خلال تضمين هذه المهار ات في الأنشطة التعليمية في مقررات الثقافة الإسلامية للمرحلة الثانوية، والتي تهدف إلى تحديد المشكلة، وجمع معلومات عنها، واختبار أفضل البدائل والحلول وثم إصدار القرار المناسب في موقف معين في ضوء مجمو عة من المعايير • حدود الار اسة: اقتصرت الدراسة الحالية على مجموعة من الحدود التالية:

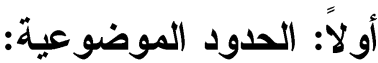

1- جميع موضوعات محور الثقافة الإسلامية المتضمنة في مقرر الحديث (1)،(ب) التعليم الثانوي (نظام المقرر ات) دون بقية موضوعات مصطلح الحديث، و الحديث النبوي. r- جميع الأشطة النعليمية الواردة في محور الثقافة الإسلامية المتضمنة في مقرر الحديث (1)،(r) التعليم الثانوي (نظام المقررات) دون بقية منظومة المنهج. ب- مهار ات اتخاذ القرار الرئيسة، والتي عليها نسبة اتفاق كبيرة في الأدبيات التزبوية، و الدراسات السابقة وهي (تحديد المشكلة، جمع المعلومات، تحديد البدائل، الاختيار بين البدائل، إصدار القرار) فقط دون بقية المهار ات الأخرى. 
ثانياً: الحدود المكانية:(قتصرث الدراسة على محور الثقافة الإسلامية من مقرر الحديث (1)،(Y) التعليم الثانوي (نظام المقررات) و المعتمد في مدارس (نظام المقررات) الثانوية بالمملكة العربية السعودية. ثالثاً: الحدود الزمانية:طبقت هذه الدراسة على محور الثقافة الإسلامية من مقرر الحديث

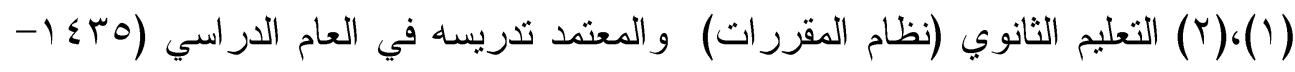
.(0) $\leqslant$ ry

إجراءات الار اسة وخطواتها: اتبعت الدر اسة الحالية الإجر اءات البحثية الآتية :

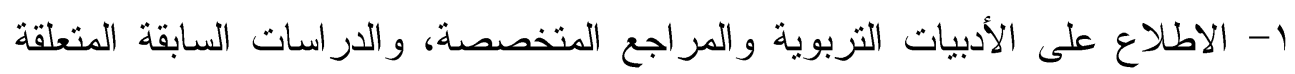
بموضوع الدر اسة. r- إعداد قائمة مهار ات اتخاذ القرار اللازم تضمينها في مقرر الثقافة الإسلامية للمرحلة الثانوية في ضوء مجمو عة من الخطوات الآتية: أ- تحديد الهدف من إعداد القائمة.

$$
\text { ب- تحديد مصادر إعداد القائمة. }
$$$$
\text { جـ- الصورة الأولية لقائمة مهار ات اتخاذ القر ارد . }
$$

د- ضبط الأداة (قائمة مهار ات اتخاذ القرار)، ذلك من خلال تحقيق الصدق،

$$
\text { و الثبات للقائمة. }
$$

ه- صباغة قائمة مهار ات اتخاذ القرار في صورتها النهائية.

ب- إعداد استمارة التحليل وفقاً للخطوات الآثية: أ- تحديد الهدف من التحليل. ب- تحديد فئات التحليل. جـ- تحديد وحدة التحليل. د- تصميم استمارة التحليل. ه- خطو ات عملية التحليل. و - التحقق من الثبات عن طريق إعادة التحليل . 


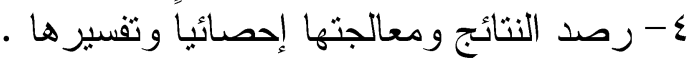

0- تقديم تصور مقتزح في ضوء تتمية مهار ات اتخاذ القرار .

ج-تقديم مجموعة من التوصيات و المقترحات في ضوء ما أسفرت عنه نتائج الدراسة

الحالية.

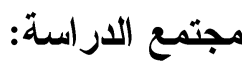

تكوّن مجتمع الدراسة من: محور الثقافة الإسلامية المتضمن في مقرر الحديث (1) التعليم الثانوي (نظام المقررات) البرنامج المشترك، ومحور الثقافة الإسلامية المتضمن في مقرر الحديث (Y) التعليم الثانوي (نظام المقررات) البرنامج التخصصي. عينة الار اسة:

تكِّ نت عينة الدراسة من : جميع الأنشطة النعليمية الواردة في محور الثقافة الإسلامية البرنامج المشترك، وجميع الأنشطة التعليمية الواردة في محور التقافة الإسلامية البرنامج النخصصي. منهج الدراسة: اعتمدت الدر اسة الحالية على المنهج الوصفي القائم على تحليل المحتوى.

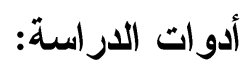
تمثلت أدوات الدراسة الحالية في الأداتين التاليتين : 1- قائمة ببعض مهار ات اتخاذ القزار اللازم تضمينها في أنشطة مقرر الثقافة الإسلامية للمرحلة الثانوية (من إعداد الباحثة). r- استمارة تحليل الأنشطة التعليمية الواردة في مقرر الثقافة الإسلامية للمرحلة الثانوية (من إعداد الباحثة). وفيما يلي خطوات إعداد الأداتين السابقتين: 
1- قائمة ببعض مهارات اتخاذ القرار اللازم تضمينها في أنشطة مقرر الثقافة الإسلامية للمرحلة الثانوية. اتبعت الباحثة عدداً من الخطوات لبناء أداة الدراسة، تمثلت في الثالي: التئ أ- تحديد الهدف من القائمة:

كان الهاف من إعداد هذه القائمة تحديد مهار ات اتخاذ القرار المناسبة لطلاب/طالبات المرحلة الثانوية، و اللازم تضمينها في مقرر الثقافة الإسلامية لتتميتها لديهم. ب- تحديد مصادر إعداد القائمة:

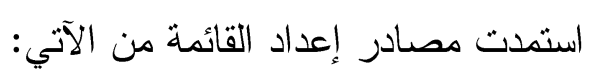

1- من الأدب التزبوي و بعد الاطلاع على المهارات التي تتاولتها البحوث و الدراسات التهات

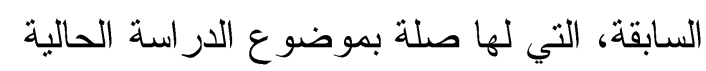

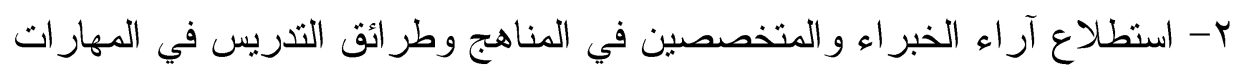
المناسبة لطلاب/طالبات المرحلة الثانوية. جـ- إعداد قائمة مهارات اتخاذ القرار في صورتها الأولية:

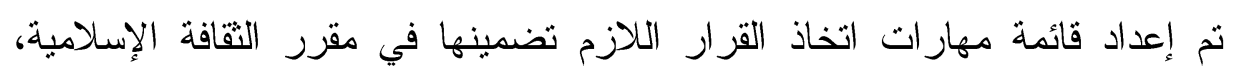

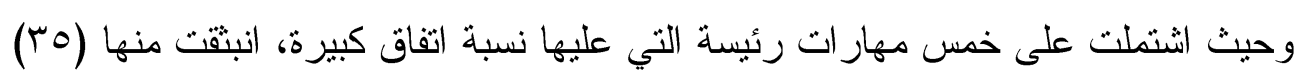
مهارة فرعية'. د- ضبط الأداة (قائمة مهار ات اتخاذ القرار) وذللك من خلا التالي: أولاً: صدق الأداة:

اعتمدت الباحثة في التأكد من الصدق الأداة من خلال نوعين من الصدق، هما كالآتي:

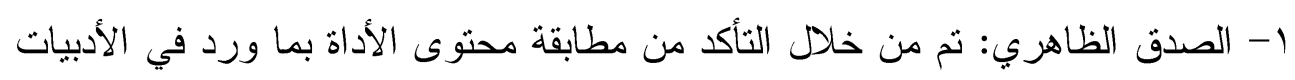
و الدراسات السابقة و البحوث و الدراسة الاسنطلاعية. 
أو فصل المهارات المركبة...وغيرها، فقد أصبحت القائمة خلالها جاهزة لقياس ما وضعت لأجله، وتم صياغة القائمة في صورنها النهائية، بحيث اثنملت على خمس

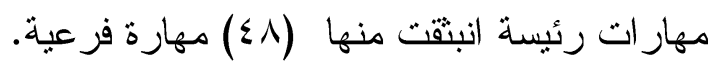
ثانياً: استمارة تحليل مهار ات اتخاذ القرار: اتبعت الباحثة عدداً من الخطو ات لبناء استمارة التحليل، تمثلت في الآتي: 1- الهدف من التحليل: تهدف الدراسة الحالية إلى الكشف عن مدى تضمين مهار ات اتخاذ القرار في مقرر الثقافة الإسلامية للمرحلة الثانوية (نظام المقررات) بنين/بنات. Y - تحديد فئات التحليل: تمثلت فئات التحليل في خمس مهار ات رئيسة، تحديد المشكلة،

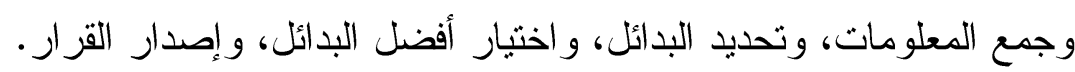
r- تحديد وحدة التحليل : اعتمدث الدراسة الحالية على وحدة (النشاط) لرصد تكرار

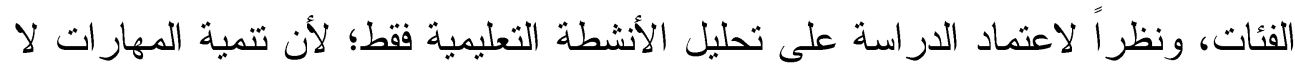
يمكن تتميها إلا من خلال النشاط، فقد تم اختبار ها لمناسبتها لهدف عملية التحليل. ع- تصميم استمارة التحليل : نم تصميم الاستمارة على شكل جدول ثنائي، يتضمن محورين أحدهما فئات التحليل، و الآخر وحدات التحليل. ه- خطوات عملية التحليل : تمت عملية التحليل لمقرر الثقافة الإسلامية للمرحلة الثانوية ولات (نظام المقرر ات)، وفقاً للخطو ات الآتية: أ- الاطلاع على الأنشطة التعليمية لمقرر الثقافة الإسلامية للمرحلة الثانوية (نظام

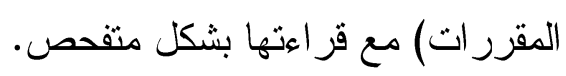
ب- إحصاء عدد الدروس، و عدد الأنشطة التعليمية، و عدد الساعات. ج- تصنيف كل نشاط إلى فئات التحليل المحددة مسبقاً. د- تحليل نشاط كل كتاب على حدة. ه- اعتماد المهارات التي تظهر في النشاط بصورة صريحة، أو ضمنية دليلاً على

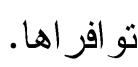
و - رصد تكرار ات مهار ات اتخاذ القرار في بطاقة التحليل. ز - ثفريغ نتائج مهار ات اتخاذ القرار في بطاقة التحليل. 
צ- التحقق من ثبات التحليل :

عمدت الباحثة في الدراسة الحالية على استخدام طريقتين: الطريقة الأولى (الثبات بين المحلل ونفسه) في ثبات التحليل، ووفق هذه الطريقة قامت الباحثة بإجراء عملية التحليل لكتب الثقافة الإسلامية للمرحلة الثانوية (نظام المقررات)، وبناءً على الأداة التي تم إعدادها سابقاً، وبعد مضي شهر من التحليل الأول، قامت الباحثة بإجر اء التحليل الثاني

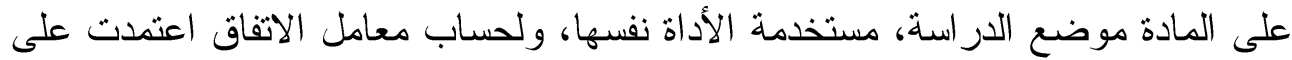
معادلة كوبر Cooper، مو التي نص على مونى

$$
\begin{aligned}
& \text { نسبة الاتفاق= } \\
& \text { عدد مر ات الاتفاق + عدد مر ات الاختلاف. }
\end{aligned}
$$

وقد قامت الباحثة بعد الانتهاء من التحليل الثاني بتطبيق المعادلة السابقة، حيث بلغت نسبة الاتفاق بين التحليلين في مقرر التقافة الإسلامية البرنامج المشترك التعليم الثانوي نظام المقررات (؟14.9\%)، وفي مقرر الثقافة الإسلامية البرنامج التخصصي التعليم الثانوي نظام المقررات (ع ؟9,\%\%)، ومعامل الثبات الكلي بين التحليلين لأنشطة مقرر

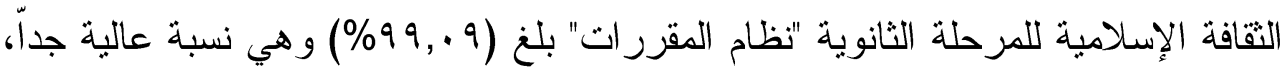
تطمئن الباحثة على ثبات التحليل. الطريقة الثانية: الثبات بين مجموعة من المحللين، ووفق هذه الطريقة قام الأستاذ المشارك بقسم المناهج وطرائق تدريس اللغة العربية/ أيمن مصطفى عبد القادرّاء

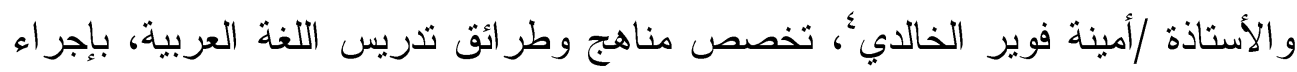

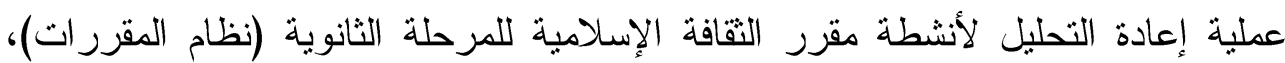

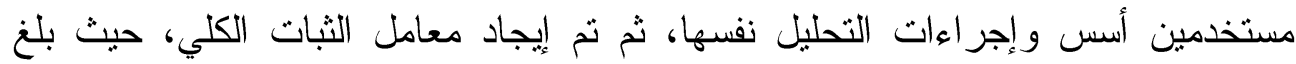

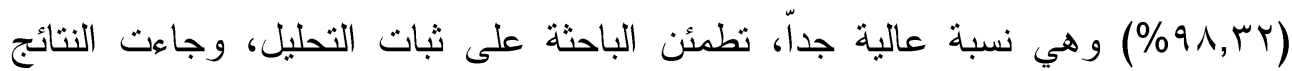
مبينة كالآتي: 
خامساً: الأساليب الإحصائية المستخدمة: أُعتمدت الدراسة الحالية لمعالجة البيانات الأساليب الإحصائية على برنامج الحزم الإلئية

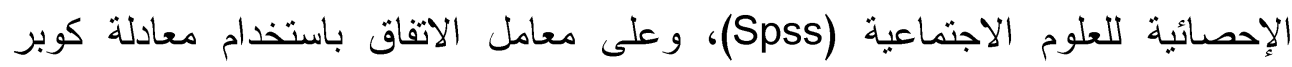
(Cooper) الاطار النظري:

\section{أهمية تدريس الثقافة الإسلامية لطالب/الطلبة المرحلة الثانوية}

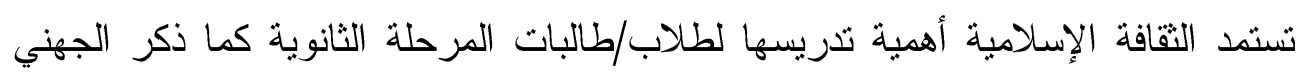

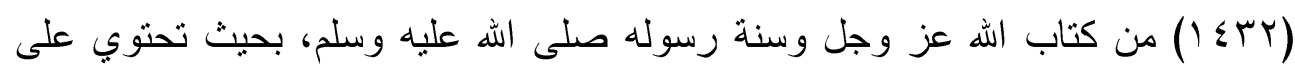

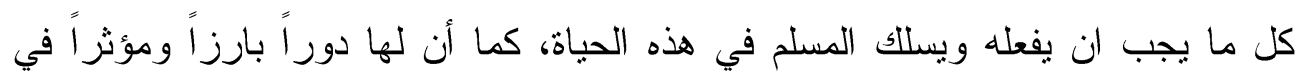

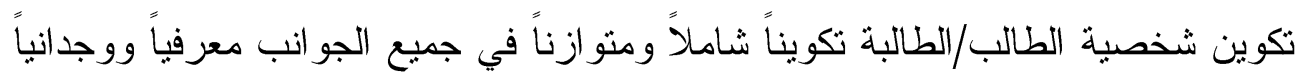

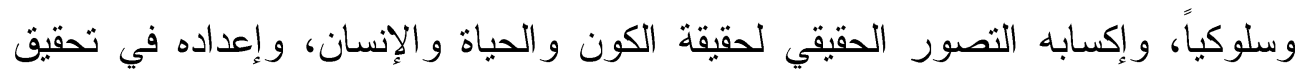

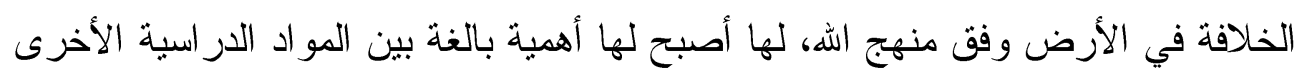

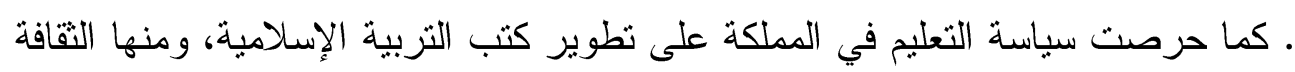

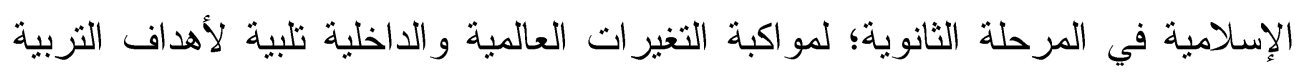
و النعليم.

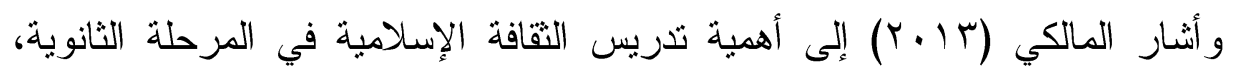

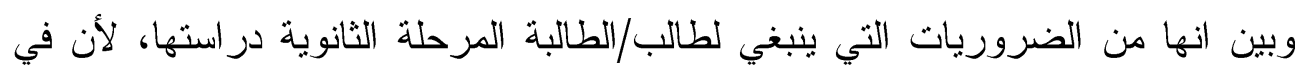

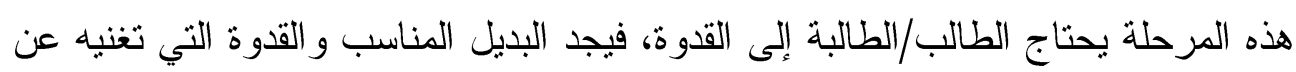

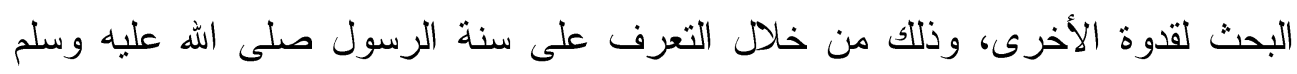

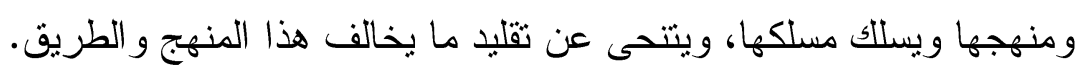

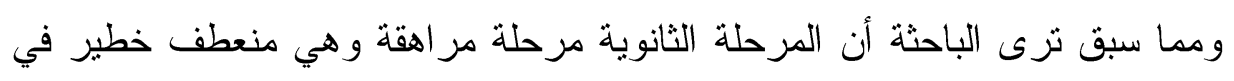

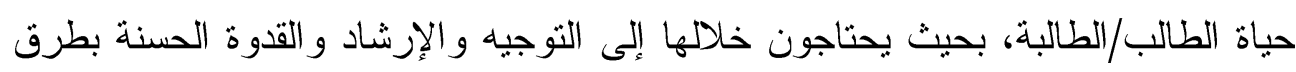

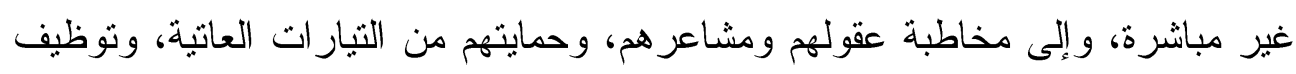

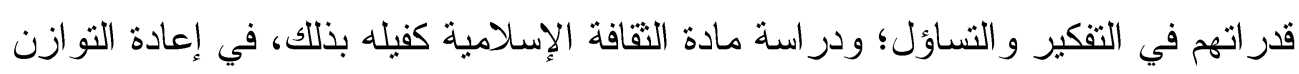


إلى حياتهم، وتكوين شخصيات قيادية، وتسلحهم بالفكر الواعي من خلال التعرف على سيرة الرسول صلى الله عليه وسلم وصحبه الكرام و السلف الصالح والاقتداء بهم.

\section{التوجهات لتطوير تلريس مناهج الثقافة الإسلامية}

إن تدريس التربية الإسلامية عامة و الثقافة الإسلامية خاصة، يرتبط بمدى سلامة إعداد

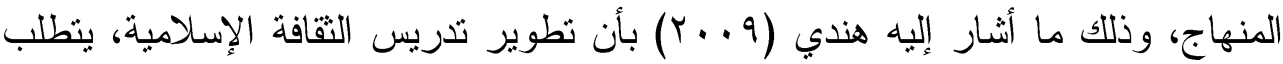

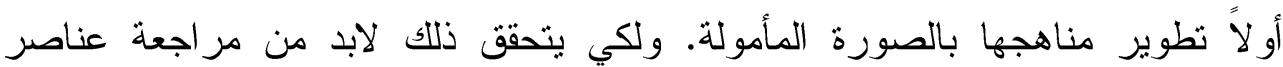

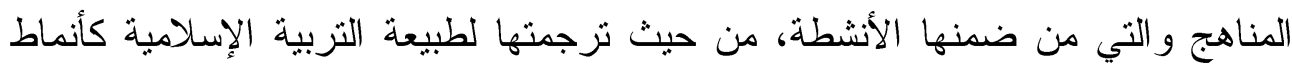
بحث وتقكير، ومر اعاتها لطبيعة المجتمع، وحاجاته وتحدياته، و القدرة على مواجهة مشكلاتها وحلها، والأخذ بالاتجاهات التزبوية الحديثة في التدريس، والأخذ بنتائج وتوصيات الدر اسات و البحوث التعليمية.

وترى الباحثة أن الاهتمام بتتمية التفكير لدى المتعلمين، وتقويم مناهج الثقافة الإسلامية بما يتتاسب مع مشكلات الطالب/ الطالبة، واحتياجاتهم التعليمية، والقضايا المعاصرة الني تحتاج إلى اتخاذ قرارات صحيحة حبالها، و إدراج الأنشطة التعليمية الصفية و اللاصفية، و الاهنمام بالاستر اتيجيات، و البرامج التعليمية التي تساعد على ذلك، من أهم الاتجاهات التزبوية الحديثة لتدريس مناهج الثقافة الإسلامية، و الدراسات و البحوث

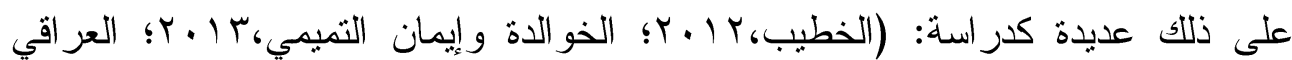

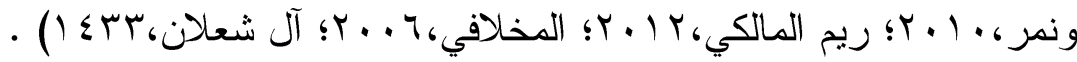
خطوات ومهارات اتخاذ القرار تشير الكثير من الدراسات والأدبيات إلى أن هناك مجموعة من الخطوات أو المر احل المتعددة والمتتابعة و المنطقية، و التي تسير خلالها عملية اتخاذ القرار، لكن اختلف الباحثون حول تحديد هذه الخطو ات ومهار اتها وترتيبها .

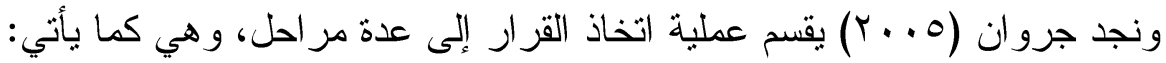

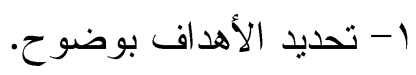

r- تحديد جميع البدائل الممكنة و المقبولة. r- تحليل البدائل بعد جمع المعلومات الو افية. 
ع- ترتيب البدائل في قائمة أولويات . م- مانمات

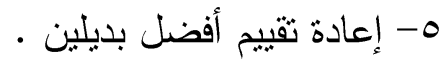
1- اختيار أفضل البدائل.

كما يرى العزيز (9. . ب) أن عملية اتخاذ القرار تتطلب وجود سلسلة من الخطوات وهي، كما يأتي:

1- تحديد المشكلة التي تثعلق باتخاذ القرار. r- جمع المعلومات اللازمة.

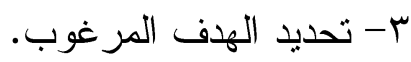
ع - تحديد جمع البدائل الممكنة و المقبولة. 0- ترتيب البدائل على شكل قائمة أولويات. 7- إعادة ثقيم أفضل بديلين أو ثلاثة. ويرى زيتون (r · . r) أن عملية اتخاذ القرار تمر في عدة مر احل، وهي كما يأتي: 1- وجود قضية أو موقف يتطلب من الانسان الاختيار بينهما. r- جمع معلومات حول كل اختيار .

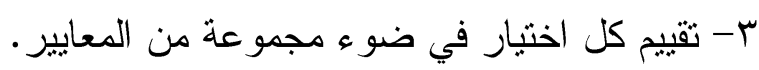
ع- تزتيب الاختيار ات على حسب الافضلية. 0- اختيار أفضل البدائل.

ويرى العجمي (1 . . r) أن خطوات اتخاذ القرار يتقق مع منطلبات البحث العلمي

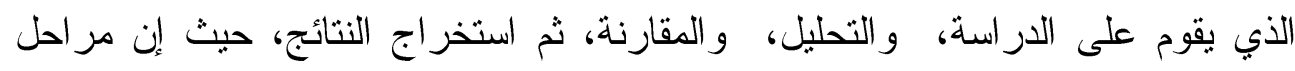
اتخاذ القز ار، و هي كما بأتي:

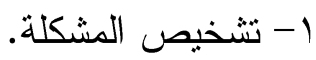

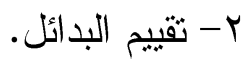
r- اختيار الحل المالائم. ع- متابعة تنفيذ القرار .

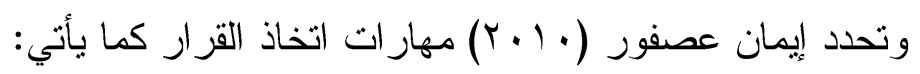


1- تحديد الهدف.

r- التفكير في النتائج المثرثبة على كل بديل. r- تحليل الموضوع ووضع البدائل. ع- اختبار البديل المناسب. كما حدد محمد (11) ب مهار ات اتخاذ القرار، و وهي على النحو الآتي: 1- تحديد المشكلة المر اد اتخاذ قرار حيالها. r- ت بديد البدائل الممكنة.

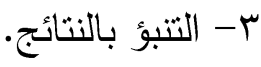
ع - نرتيب البدائل في قائمة على حسب الأولوية. 0- اختبار افضل البدائل.

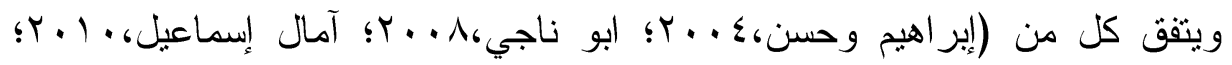

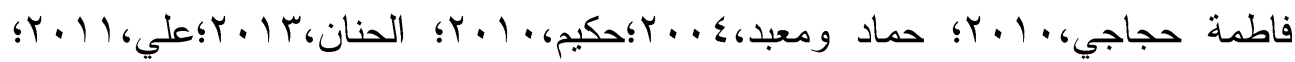

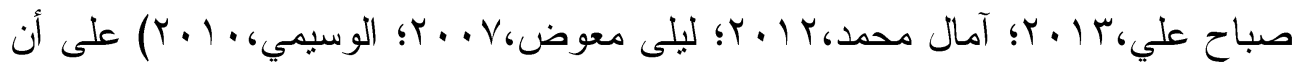

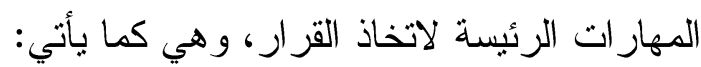
1 - 1 - تحديد المشكلة.

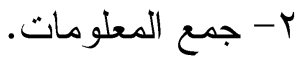

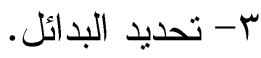

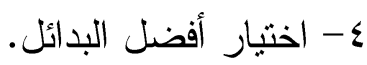
0- - م- إصدار القزار.

ومما سبق ترى الباحثة اختلاف الباحثين في تحديد مهارات اتخاذ القرار كان من حيث العدد و الثزتيب و المعنى، ولم يكن من حيث الهدف و المضمون الذي تسعى إليه عملية اتخاذ القرار، وفي الدراسة الحالية سوف يتم استخدام مهار ات اتخاذ القرار الرئيسة و التي علبها نسبة اتفاق كبيرة، وهي كما يأني: 1 - 1 - تحديد المشكلة.

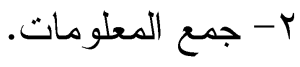




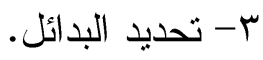

ع- - اختيار أفضل البدائل.

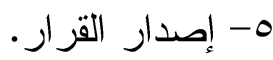

تصنيفات اتخاذ القرارات

يصنف الباحثون القرارات التي يمكن للفرد اتخاذها في الظروف المختلفة كما يأتي: ا- قرارات يأخذها الفرد في حالة اليقين أو التأكد إذا كان يعرف بأن كل اختيار يؤدي إلى نتيجة معروفة على وجه التأكيد. ץ- قرارات يأخذها الفرد في حالة الثك أو عدم النأكد، وذلك عندما يقود كل اختيار إلى عدة نتائج ممكنة، ولكن احتمالاتها غير معروفة. ب- قرار ات يأخذها الفرد في حالة المخاطرة إذا كان كل اختيار يقود إلى نتائج احتمالاتها معروفة كالموت و الحروق. ع- قرار ات يأخذها الفرد في حالة الثك، و المخاطرة، أو الجهل عندما لا يكون الثخص متأكداً من درجة احتمالية النتائج، ولكن تثوافر لدية معلومات يسنطيع ثقدير نسبة نجاح

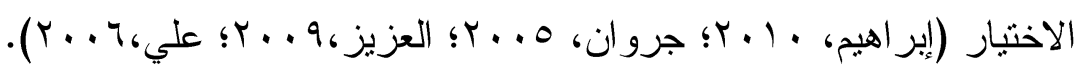
كما صنف بعض التزبوبين القرارات إلى قرارات مهنية، وشخصية، ورسمية، وروثينية، ومبرمجة، وغير مبرمجة، وقرارات تشتمل على بدائل متعددة الأهداف، وقرارات تشتمل على بدائل ذات هدف واحد، وقرارات متعددة المراحل، وقرارات ذات المرحلة الو احدة، وقرار ات تتسم بالمخاطرة وقرار ات لا تمثل مخاطرة، وقر ار ات انفر ادية وقرار ات جماعية، وسطية واستئنافية و ابتكارية، كيفية وكمية، وقرار ات تتعلق بالفرد،

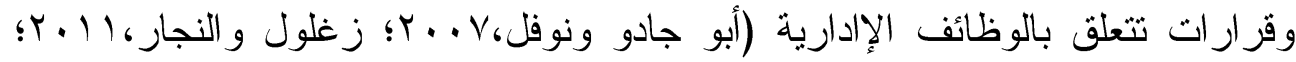

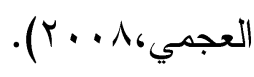

\section{خصائص مهار ات اتخاذ القرار}

تتميز مهار ات اتخاذ القرار بأنها مهارة عقلية يمكن تطويرها، ويمكن تتميها لدى الطلبة خلال تدريبهم على التفكير، وابتكار البدائل، وتكون أحياناً معقدة، ومركبة، واحياناً

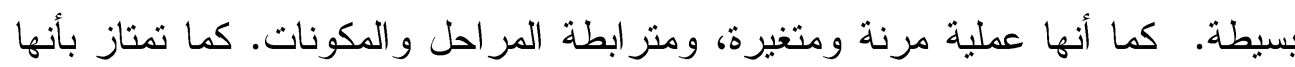


استمر ارية تمتد عبر الزمن، حيث تتصل بالماضي، وتزتبط بالحاضر ، وتتطلع للمستقبل، ومقيدة بقيم الفرد و عاداته وخبر اته. كما أنها عملية ديناميكية تنتقل من مرحلة إلى أخرى ونى تحقيق الهدف المنشود، ومتكاملة، وشاملة حيث يمكن تطبيقها في كل أنواع القرارات

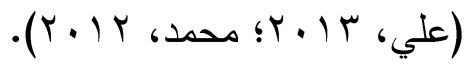

وتزى الباحثة من خصائص مهار ات اتخاذ القرار بالإضافة إلى ما سبق، ما بأني: 1- مهار ات منظمة: بمعنى أنها تتم وفق نظام منظم، ثبدأ بتحديد المشكلة، ثم جمع معلومات، ثم اقتر اح بدائل، و اختيار أفضل البدائل، ثم إصدار قرار . l - مهار ات هادفة: بمعنى أنها تتطلق من أهداف معينة، حيث تسعى في تحديد مدى تحقيقها لتلك الأهداف.

r - اقتصادية: بمعنى أنها غير مكلفة مادياً، ويمكن تتفيذها على الو اقع الفعلي.

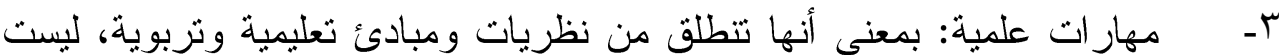
مجرد اجتهادات ورؤى فردية وشخصية. ع- مهار مات مناسبة: بمعنى أنها تتنقي التوقيت المناسب، و والبدائل المناسبة، و المعلومات المناسبة عند إصدار القرار . اتخاذ القرارات في الإسلام

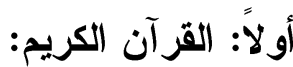

نجد في القرآن الكريم الكثير من الأمثلة التي أشارت إلى استخدام مهارات عملية اتخاذ القرار، ونجد ذلك جلياً واضحاً في عرض قصص الأنبياء، وفي كثبر من المشكلات و الأمور، التي اعترضت سبيل الدعوة إلى الله تعالى، ومن ذللك قصة أصحاب الكهف حيث ذكر الله سبحانه وتعالى في هذه القصة أن فتية آمنو ا بربهم، وكانو ا يعيشون في قرية إنية يعبدون غير الله، فكانو أمام خيارين إما البقاء في منازلهم المريحة، أو الخروج من القرية حفاظاً على دينهم، فما كان قرر اهم إلا الخروج إلى كهف يتعبدون الله. و وكذلك موقف اله سليمان عليه السلام عندما أراد أن يحضر عرش ملكة سبأ استمع إلى البدائل، ثم أختار

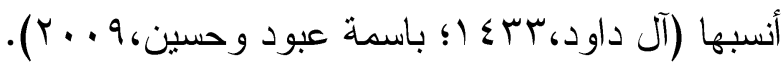


و أشار العامري (ع (1)) إلى أن عملية اتخاذ القرار تتكرر في القرآن الكريم، ومن ذلك قصة موسى عليه السلام مع السحرة، وفيها يتضح لنا صورة من صور اتخاذ القرار وهي المفاضلة بين بديلين، بحيث يتم اختيار البديل الأفضل، فجاء اختيار موسى عليه السلام للبديل الثاني عندما قال لهم : ألقوا. و القرآن الكريم يخبرنا عن تفاصيل اتخاذ القرار

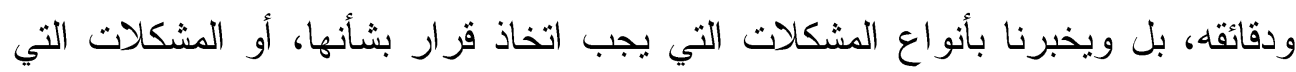

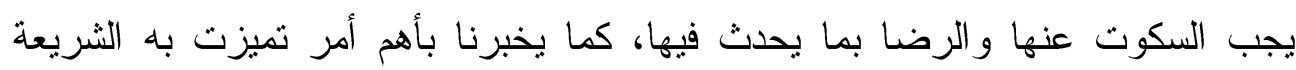
الإسلامية، وهو مبدأ الشورى .

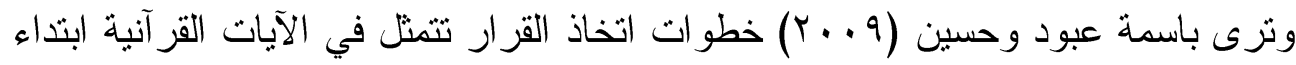
من الثعور بالمشكلة إلى الوصول للحل المناسب، كما في قصة ذي القرنين حينما وصل

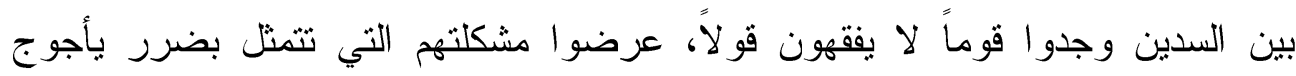
ومأجوج، إلى ذي القرنين؛ ولما يتمتع من إمكانات منميزة، طلبو ا منه أن يجعل بينهر سداً

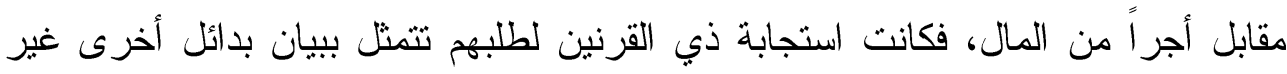

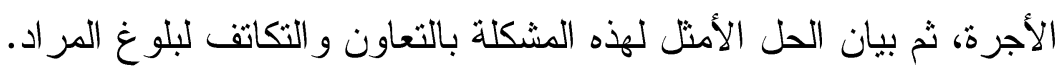

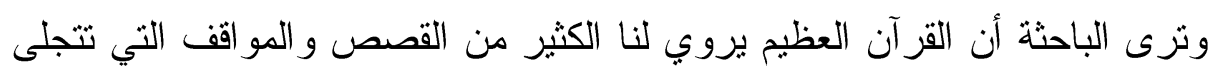

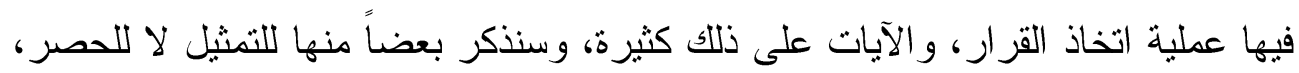
و وعلى حسب اعثقاد الباحثة: 1 - مهارة تحديا المشكلة:

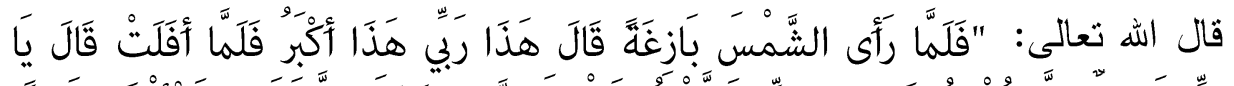

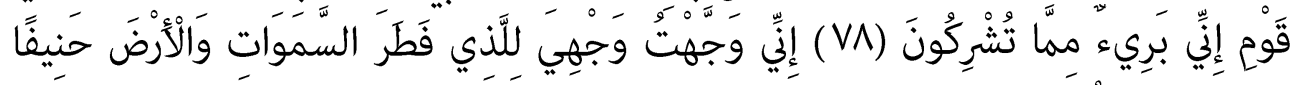

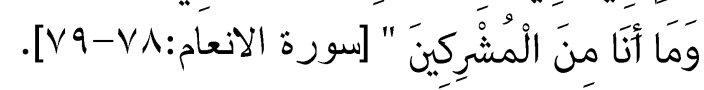

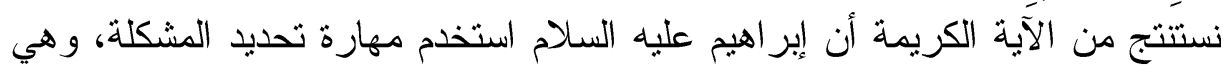
عبادة قومه للكو اكب، فكان مناظراً لقومه مبين لهم بطلان عبادتهم، حيث كان أشرفها

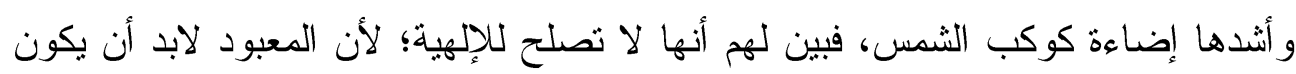

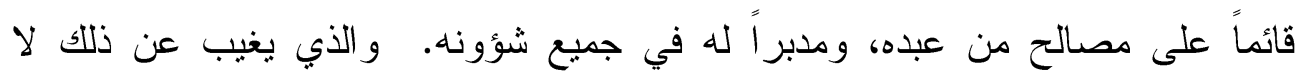

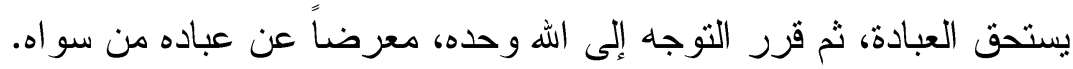


Y - بهارة جمع المعلومات:

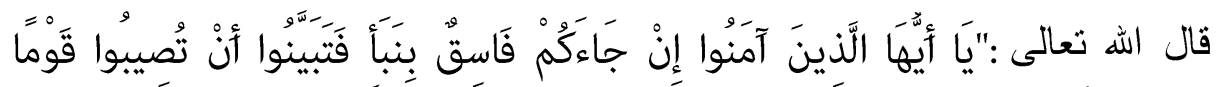

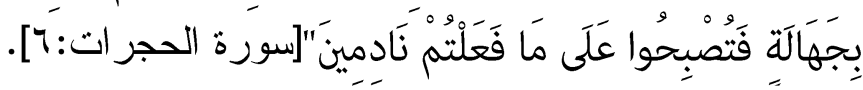

نستنتج من الآية الكريمة استخدام مهارة جمع المعلومات، ومعرفة مصادرها، وصحتها، و التثبت و التبين من صدق المعلومات و الاخبار المنقولة من عدمه، فلا نأخذها مجردة لأن في ذلك تحصل الندامة، و الوقوع في الإثم، فإذا دلت الدلائل و القرائن على صحة المعلومات عملت بها، و إن دلت على عدمه ترد و لا تعمل بها.

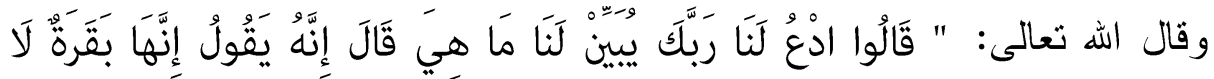

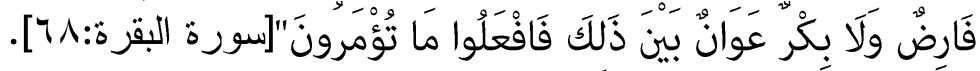

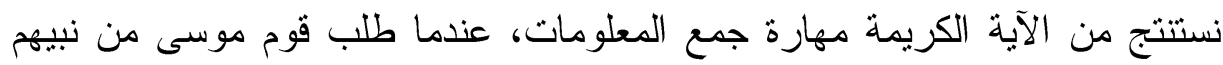

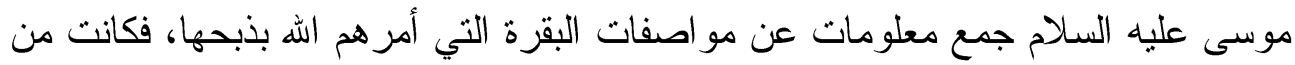
صفاتها انها بقرة لا كبيرة، و لا صغيرة، لونها صفراء فاقع تسر الناظرين من حسنها،

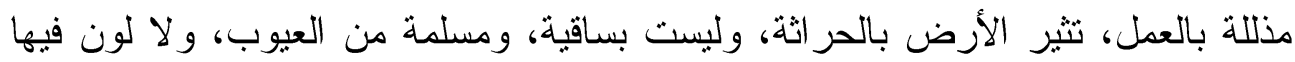

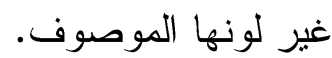

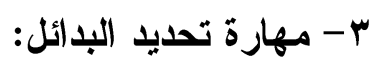

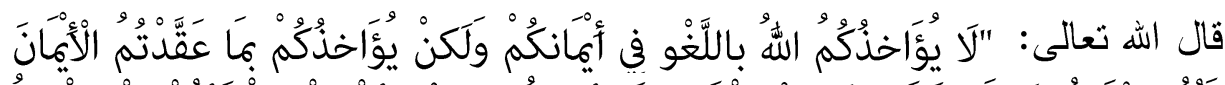

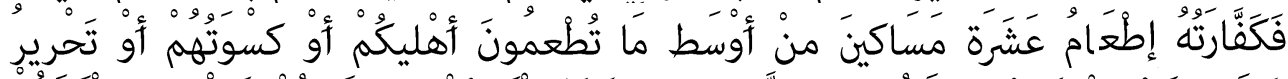

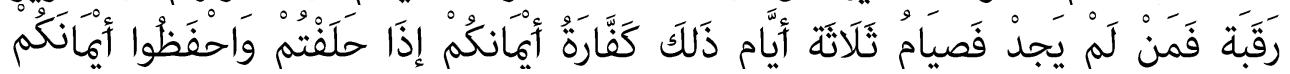

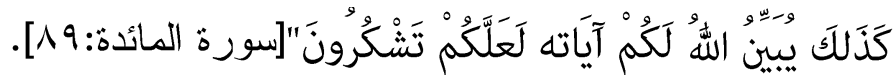

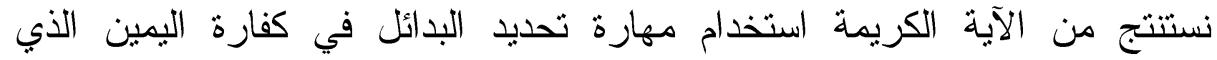
عقدموها بقصدكم وهي، البديل الأول: إطعام عشرة مساكين، البديل الثاني: كسوتهم، البديل الثالث: تحرير رقبة، البديل الرابع: صيام ثلاثة أيام.

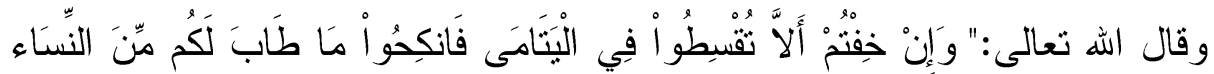

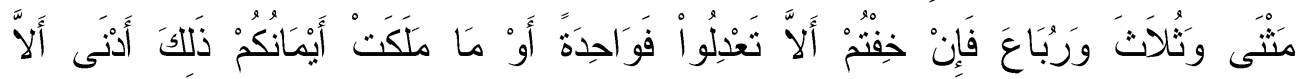

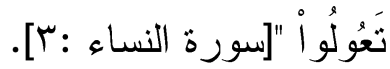


كما نستتنج من الآية الكريمة استخدام مهارة تحديد البدائل في عفة النفس، لمن خاف أن لا يعدل في يتامى النساء التي تحت حجره وولايثه، وخاف أن لا يقوم بحقها لعدم محبته إياها. فلينكح ما طاب له من النساء، بحيث نجد البديل الأول : مثنى، و البديل الثاني: ثلاث، و البديل الثالث: ورباع، و البديل الخامس: أن خاف ألا يعدل فو احدة أو ما لأل ملكت اليمين.

\section{ع - مهارة اختيار أفضل البدائل:}

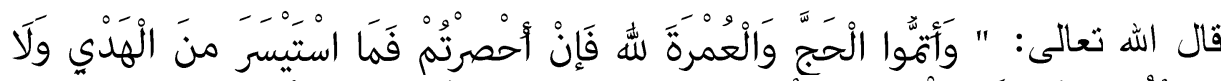

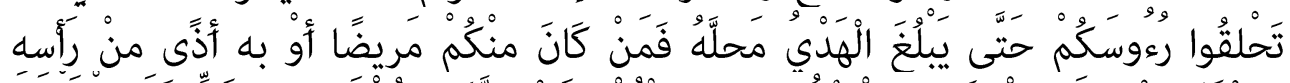

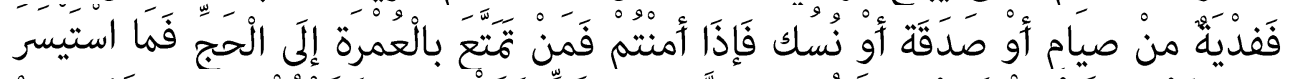

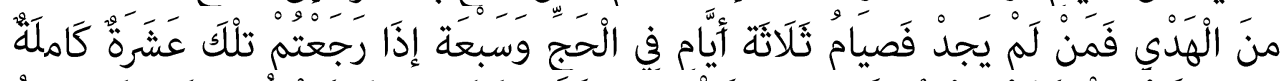

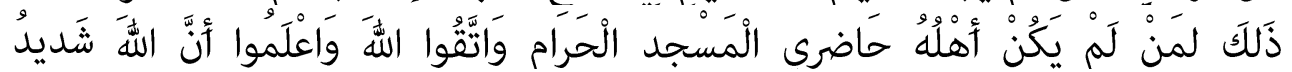

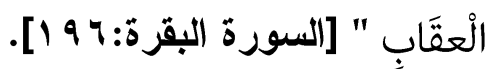
نستتج من الآية الكريمة استخدام مهارة اختيار أفضل البدائل في أحكام الحج و العمرة. حيث نجد أن من أمتتع من الوصول إلى البيت لتكميل مناسك الحج و العمرة،

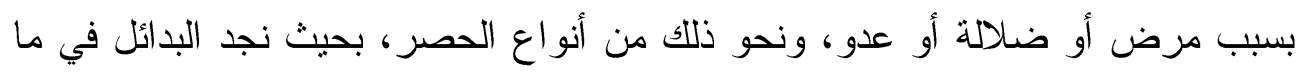

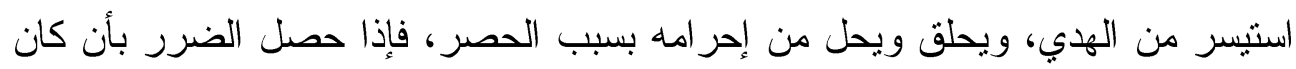

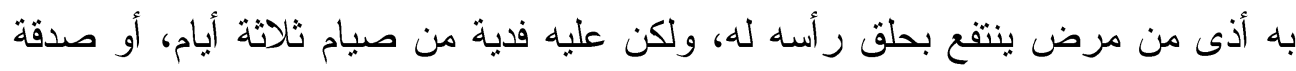

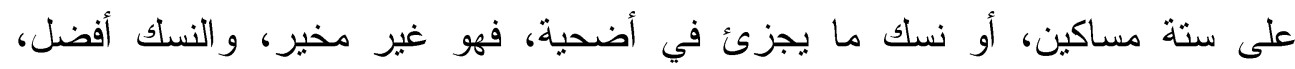
فالصدقة، فالصيام.

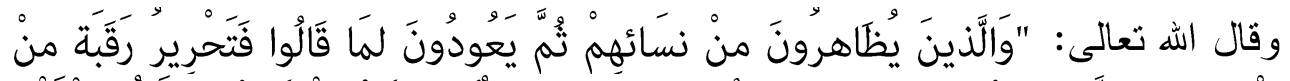

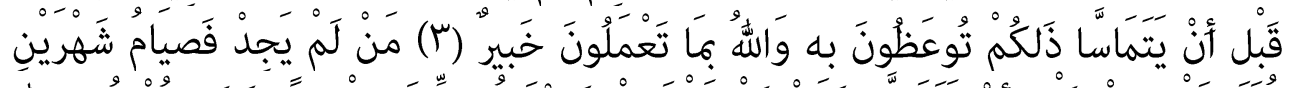

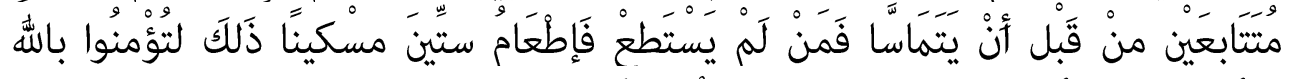

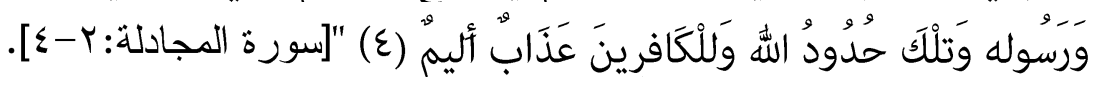

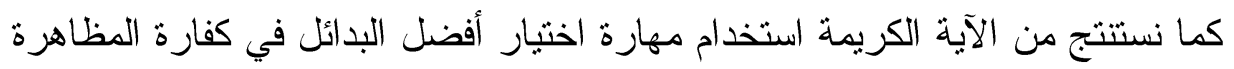

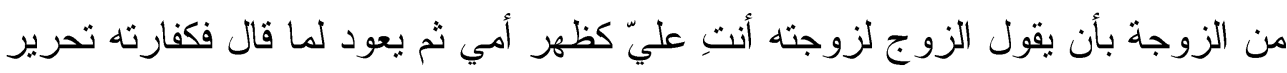

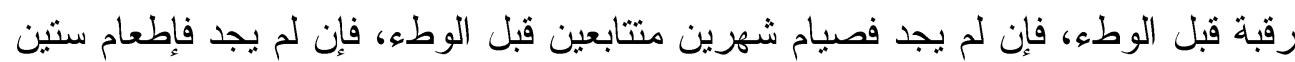


مسكين. وقد نزلت هذه الآية في خولة بنت ثعلبة عندما ذهبت نشتكي زوجها أوس إلى مالى رسول الله - صلى الله عليه وسلم- فخيره رسول الله في كفارة المظاهرة بين البدائل المذكورة سابقاً فما كان جو ابه : لا يجد إلا أن يعينه الرسول - صلى الله عليه وسلم- في وله إطعام سنين مسكين، وقد أعانه الرسول صلى الله عليه وسلم في ذلك. ه- مهارة إصدار القرار:

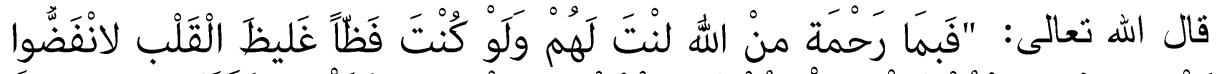

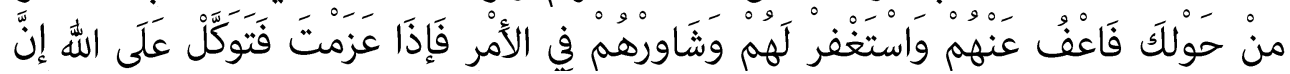

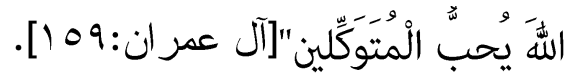

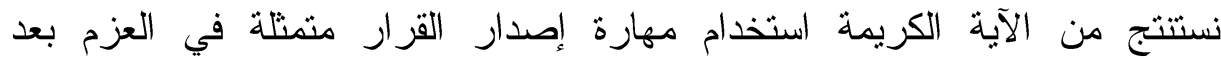
الاستشارة وتوكل على الله سبحانه وتعالى وقوته. فإذا الله تعالى يأمر رسول الله صلى الهى

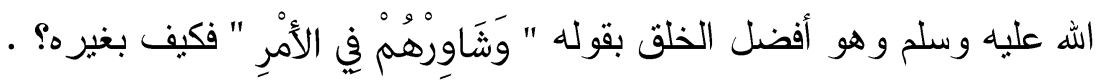
ثانياً: السنة النبوية الشريفة:

كما ترى الباحثة أن السيرة النبوية مليئة بالمواقف التي يتمثل فيها عملية اتخاذ

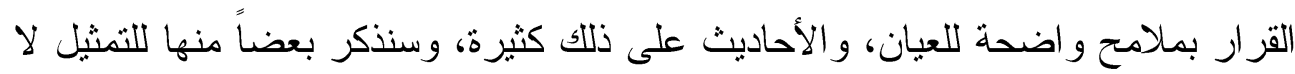
للحصر ، و على حسب اعتقاد الباحثة:

1- مهارة تحديد المشكلة:

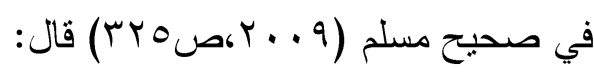
"عن عائشة رضي الله عنها قالت: أن رسول الله - صلى الله عليه وسلم- خرج من فن جوف الليل، فصلى في المسجد، فصلى رجال بصلاته، فأصبح الناس بتحدثون بذلك، رلكي،

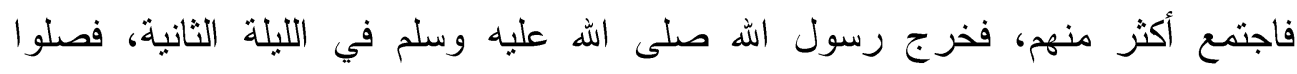
بصلاته، فأصبح الناس يذكرون ذللك، فكثر أهل المسجد من الليلة الثالثة ،فخرج، فصلو الثرا

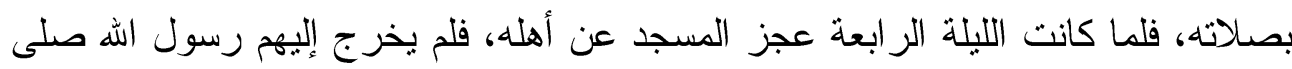
الله عليه وسلم، فطفق رجال منهم يقولون: الصلاة، فلم يخرج إليهج رسول الله صلى الله

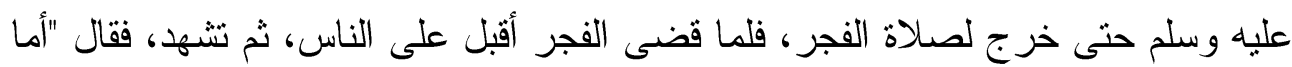
بعد، فإنه لم يخف على شأنكم الليلة، ولكني خشيث أن تفرض عليكم صلاة الليل، فتعجزوا 
ونستنتج من الحديث السابق استخدام الرسول صلى الله عليه وسلم مهارة تحديد المشكلة في عدم خروجه لصلاة الليل خشية أن تفرض عليهم فيعزورا عنها.

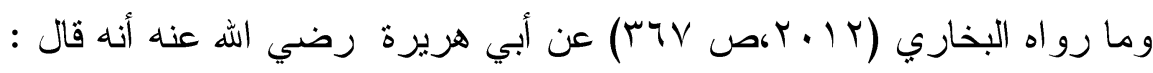

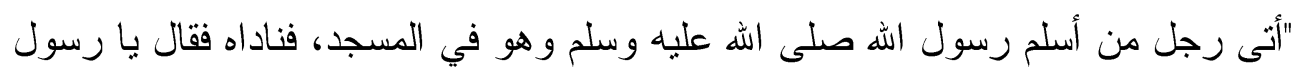

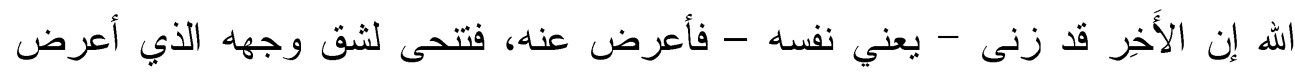

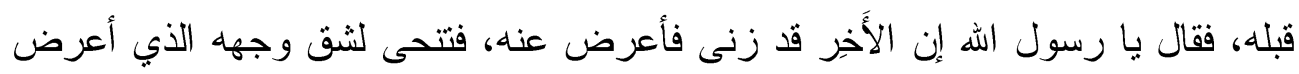
قبله، فقال له ذللك، فأعرض عنه، فتحى لله الر ابعة، فلما شهد على نفسه أربع شهادات، دعاه فقال:" هل بك جنون ؟" قال : لا ، فقال النبي صلى الله عليه وسلم :" اذهبو ابه به اله فارجموه"، وكان قد أحصن". ونستتنج من الحديث السابق استخدام الرسول صلى الله عليه وسلم لمهارة تحديد المشكلة عندما وقع الأخر في جريمة الزنى وشهد على نفسه أربع شهادات، ولم يكن به جنون فأقام عليه حد الزنى.

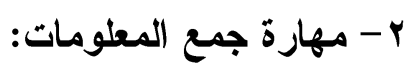

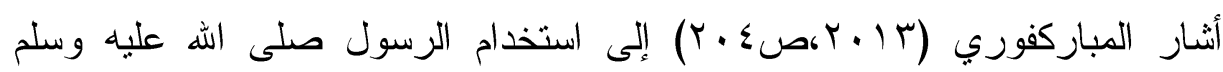
لمهارة جمع المعلومات حول قو افل قريش بقوله:

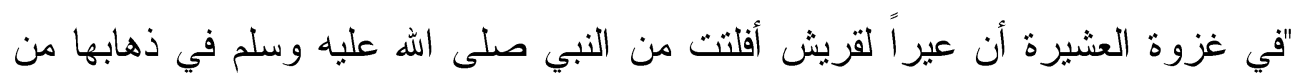
مكة إلى الشام، ولما قرب رجوعها من الشام إلى مكة بعث رسول صلى الله عليه وسلم

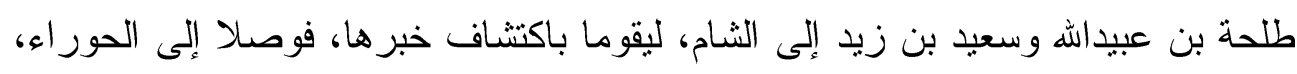

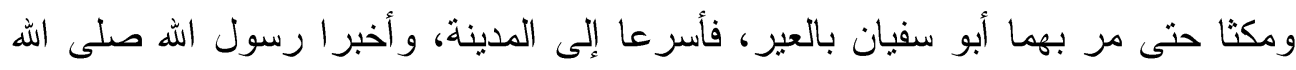

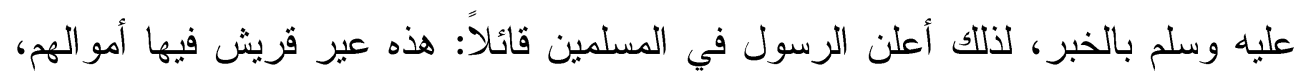
فاخرجو إإليها لعل الهه ينفلكمو ها". ب- مهارة تحديد البدائل:

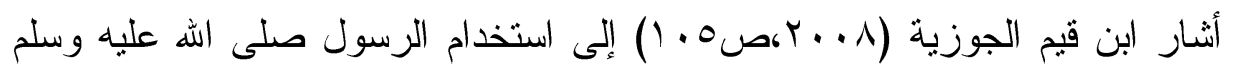
لمهارة تحديد البدائل، بقوله: "كان قيام الرسول بالليل ووثزه أنواعاً، فمنها ما روى أبو لئ 
حانم ابن حبان في صحيحه عن أبي هريرة رضي الله عنه، عن الرسول صلى الله عليه وسلم:" لا نوترو ا بثلاث، أوترو ا بخمس، أو سبع، و لا تشبهو ا بصلاة المغرب". ع - مهارة اختيار أفضل البدائل:

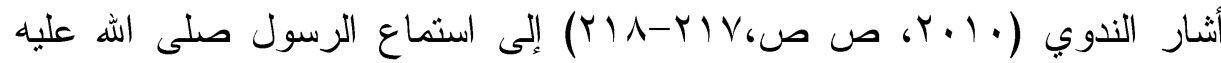
وسلم للبديل الذي عرضه عليه الحباب، و اختيار الأفضل بقوله: " عندما نزل المسلمون بجانب بدر، فجاء الحباب بن المنذر، وقال: يا رسول الله أر أيت

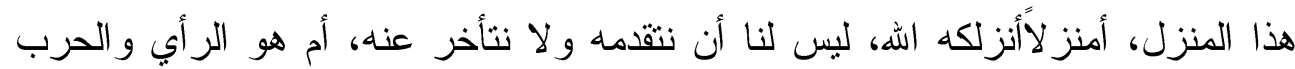
و المكيدة؟ قال: "بل هو الر أي و الحرب و المكيدة". فقال: با رسول الله، فإن هذا ليس بمنزل، وأشار عليه بأرض تصلح للحرب فقال الرسول صلى الله عليه وسلم :"لقد أشرث

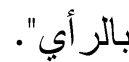

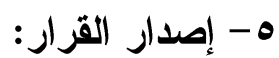

نجد الرسول صلى الله عليه وسلم إذا همً بأمر استشار، ثم بصدر قرارًا بعدها، فنجده يستشير سعد بن معاذ في محاوله مصالحة غطفان على ثلث ثمار المدينة، ونجد يستشير الناس في قضية الإفلك، ويستشير جميع الناس في الخروج لقتال المشركين في غزوة أحد، ويستشير نوفل بن معاوية في حصار الطائف.

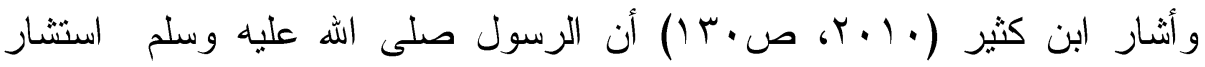
أصحابه في الخروج لقتال كفار قريش في غزوة بدر بقوله:

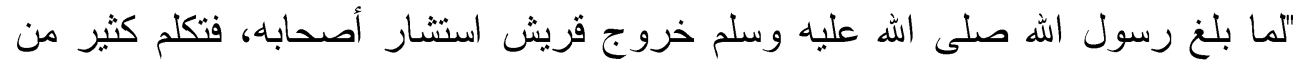

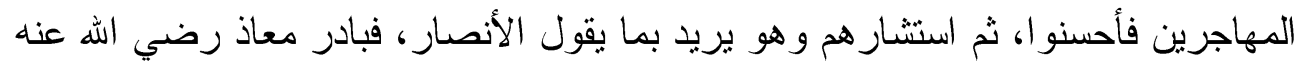

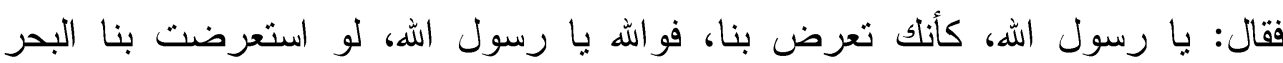
لخضناه معك فسر بنا يا رسول على بركة الله. فسر الرسول صلى الله عليه وسلم بذلك بلك وقال" سيرو او أبشرو ا فإن الله قد و عدني إحدى الطائفتين". الأهمية التربوية لتنمية مهار ات اتخاذ القرار

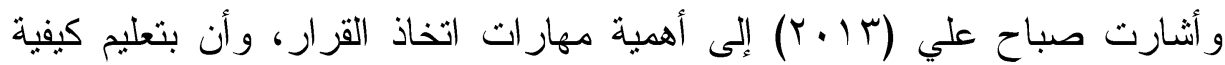
اتخاذ القرارات نعد الفرد لمواجهة الحياة بعقل واعٍ تجعله يتحمل صعوباتها و أعبائها، 
وتجعله قادراً على تشكيل حياته بصورة بصبح خلالها عضواً فعالاً في المجتمع، محافظاً على تعاليم دينه و تقاليد مجتمعه.

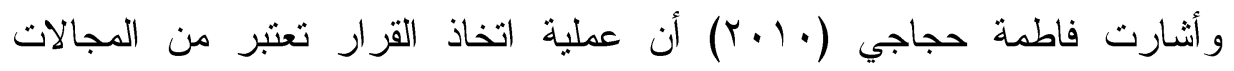
التزبوية الحديثة، وضرورة من الضرورات لحل المشكلات، و القضايا الاجتماعية، و الأخلاقية التي نشأت نتيجة تطور العلم و التقنية؛ ولذلك ازداد الاهتمام بعملية اتخاذ القزار في الفتزة الأخيرة، وتولتها التزبية بالاهتمام مثز ايد.

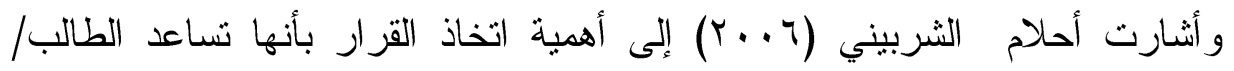
الطالبة على التقكير بعمق قبل أن يقوم باختيار مهمة في حياتهم المستقبلية كمهنة وغيرها. وتساعدهم على تحمل المسئولية، و الاستفادة من خبر اتهم السابقة، و التزيث و وعدم الاندفاع في اتخاذ القرار ما.

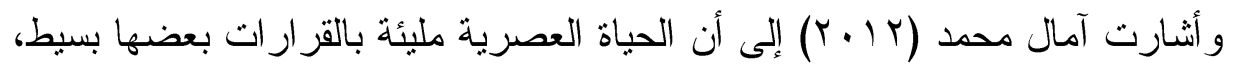

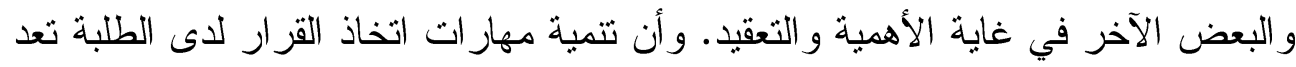

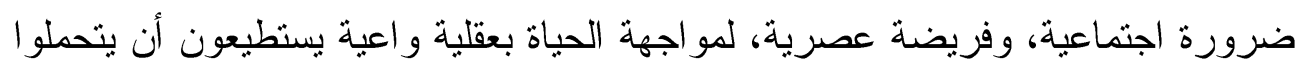
أعباءها ويشاركون بفاعلية في حل مشكلاتها.

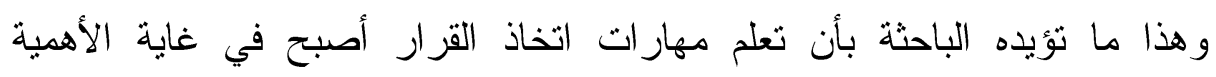
وخاصة في عصر ازدادت في المشكلات و التعقيدات، وتعددت فيه البدائل و الاحتمالات،

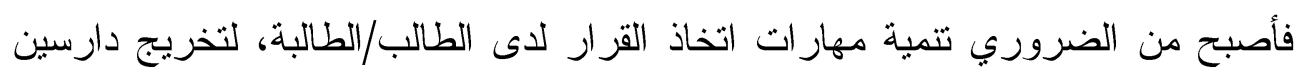
قادرين على مو اجهة صعوبات الحياة العصرية المتجددة، بشخصيات قوية، و عقول و اعية ، لحل مشكلاتهم الشخصية، ولخدمة دينهم ومجتمعهم.

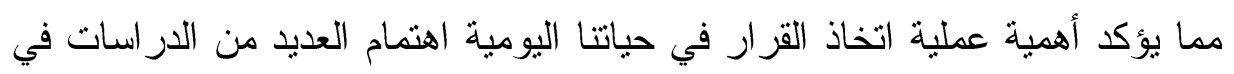
مجال التربية في مختلف المو اد الدراسية، وفي جميع المراحل التعليمية، بتتمية مهارات

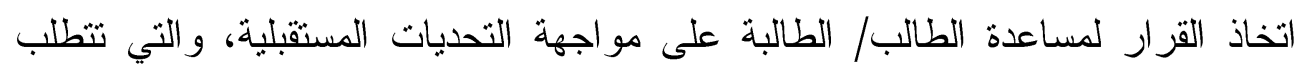
اتخاذ قرارات صحيحة نحو المشكلات التي تواجههم، ومن هذه الدراسات ما يأتي:

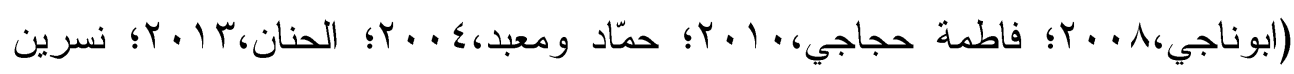




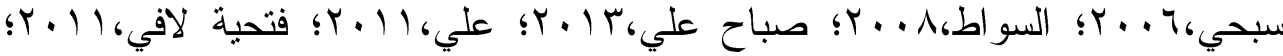

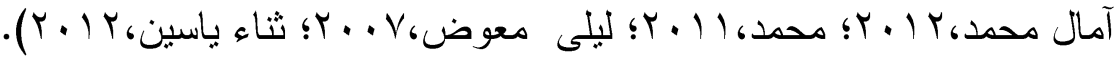
دور مناهج الثقافة الإسلامية في تنمية مهارات اتخاذ القرار برى الغامدي (11 ( ب) أن ما يميز مناهج الثقافة الإسلامية عن غيرها من المناهج أنها تعتتي عناية فائقة بتربية الأجيال في مختلف الجوانب، بما توفره من تتمية شمولية لمختلف مر احل النمو، مما يسهم في تحقيق الغايات التزبوية المنشودة على المستوى المعرفي و المهارى و الوجداني، و أثار إلى أهمية تتمية المهار ات الحياتية من خلال مناهج

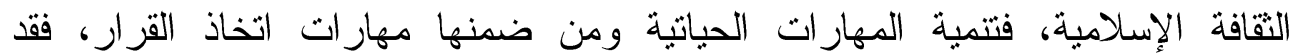
أصبحت من أهم الاتجاهات الحديثة في المجال التربوي، سعياً لإعداد الطالبة/ الطالبة إعداداً شاملاً للحياة، وقد أكد العديد من التربويين على أهمية تضمينها في المناهج .

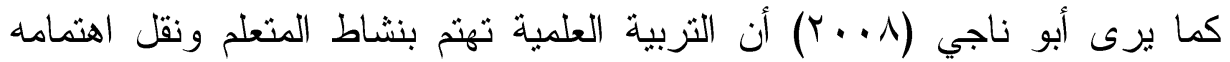

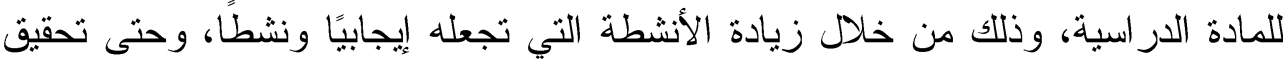
التزبية العملية هذه الأهداف اقترح البعض تتظيم المادة العلمية على هيئة أنشطة يشارك

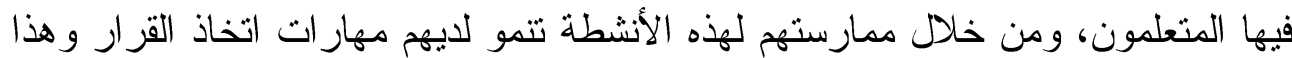
ما أكدته العديد من الدر اسات. وتزى الباحثة أن مناهج الثقافة الإسلامية تسعى إلى تحقيق العديد من الأهداف من هذه الأهداف تتمية المهار ات بمختلف أنو اعها، ومستوياتها، ومساعدة الطالب/الطالبة على الإلى اكتساب المهار ات التي تعينهم على حل مشكلاتهم العامة والخاصة، لذلك ينبغي أن تعطي مناهج النزبية الإسلامبة اهتماماً كبيراً يحتوى على فكر بياند النشاط ويدعمه، وينمي مهار ات اتخاذ القر ار وهذا ما أثنارت إليه العديد من الدراسات كدر اسة (الجديبي، آبـ )؛

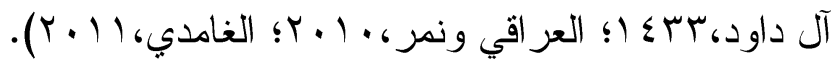
دور معلم/معلمة الثقافة الإسلامية في تنمية مهارات اتخاذ القرار.

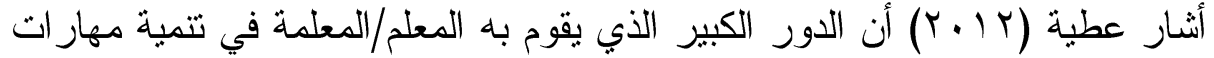
اتخاذ القرار لادى الطلبة، وذلك من خلال نشجيع الطالب/ الطالبة على المناقشة، و السماح لهم بالتعبير عما يدور في أذهانهم، وتدريبهر على اتخاذ القرار بوضعهم في مشكلات 
تتطلب الحل، وتشجيعهم على كثرة الاطلاع و القراءة الحرة، وغرس التقة في نفوسهم، وتدريبهم على اكتساب المعلومات، وتحمل المسئولية. و أثشارت فتحية لافي (11 + (1) إلى بعض الخطو ات التي يمكن للمعلم/ المعلمة إتباعها لتشجيع وتدريب الطالب/الطالبة على مهار ات اتخاذ القرار، لمواجهته للمشكلات التي

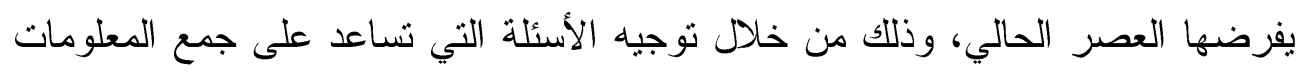
ومعالجتها، وتحديد ما بينهما من علاقات و استخدامها في مو اقف جديدة، كذلك بناء الفصل من خلال تهيئة الطالب/الطالبة للتفاعل، و استجابة المعلم لهم، و أيضا النمذجة. لذألك فان المعلم/ المعلمة مطالبون بتحديد ومناقشة القرار ات الهامة، وتصنيفها في جدول، و النتائج المنرتبة على ذلك ومساعدة الطالب/ الطالبة في إصدار الأحكام على هذه القرارات وتقييمها.

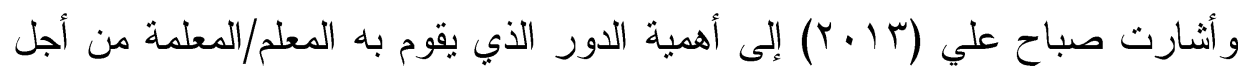
مساعدة الطالب/ الطالبة على اتخاذ قرارات صحيحة اتجاه المواقف و المشكلات التي تو اجهمه، ويتمثل هذا الدور في مناقشتهم حول مفهوم القرار المنسرع و الانفعالي، و النتائج المثرنبة على ذلك، وتقديم بعض الأمثلة و المشكلات من و اقع الحياة اليومية و المدرسية بهدف استيعابهم مفهوم القرار .

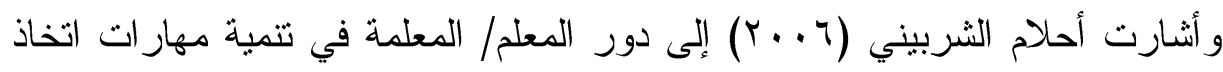
القرار خلال عملية التعليم و التعلم، وذللك من خلال تدريب الطالب/الطالبة على تصميم مهام لاتخاذ القرار عن طريق اقتر اح موضوعٍ عام يقومون باتخاذ قرار بشأنه، أو نوجيه أسئلة مشيرة للاهتمام ومرتبطة بأنشطة في مجالات مختلفة، وكذلك مناقشتهم عن أهمية اتخاذ القرار في حياتهم اليومية، وتقديم مفهوم صريح ونماذج مثتوعة عن مهار ات اتخاذ القرار، و التأكد من استيعابهم لمر احل اتخاذ القرار، ومساعدهم في تتمية الوعي بأن اتخاذ القرار يتضمن أسئلة مثل ما هو الأفضل؟ ما عو اقب اختياره؟....الخ. ترى الباحثة أن المعلم/ المعلمة ركن أساسي من أركان العملية التعليمية، وقائد تزبوي لتوصيل الخبرات و المعلومات التزبوية، والمسؤول الأول عن نجاح، أو فشل ركل

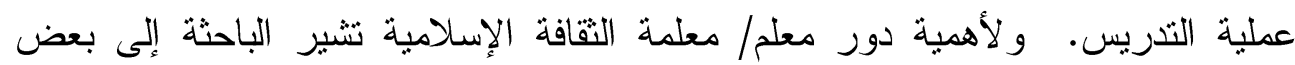


التوجهات التي يمكن أن يسترشد بها في تتمية مهارات اتخاذ القرار لدى طالب/طالبة المرحلة الثانوية وهي كالآتي:

1- يفترض على المعلم/ المعلمة طلب الاستماع إلى بعض المشكلات أو الأمور بعبار ات

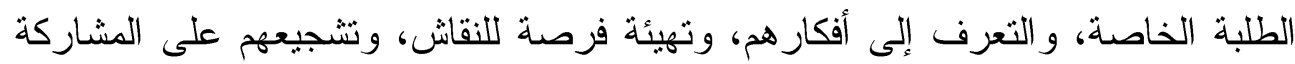
الجماعية بتوزيعهم في مجمو عات متساوية.

r- يصوغ المعلم/ المعلمة في ضوء خبرته السابقة عن طلبته بعض المشكلات

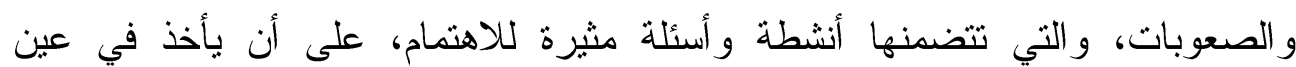
الاعتبار ما لاى الطالب/الطالبة من قدرات عقلية تمكنهم من مواجهة التحديات التي تتضمنها تلك الأسئلة و الأنشطة. ب- يعود المعلم/ المعلمة الطالب/ الطالبة على استخدام طرف التمييز، و التصنيف،

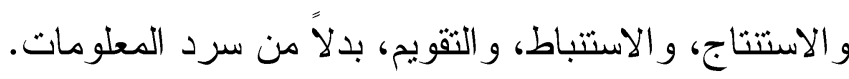

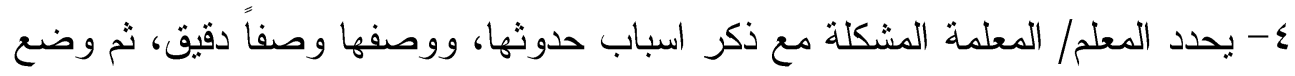
خطة لدر استها. ه- يوجه المعلم/ المعلمة الأسئلة التي تساعد الطالب/ الطالبة على جمع المعلومات، وتحديد كم ونوعية المعلومات المطلوبة، ومصادر وسبل الحصول عليها، ثم تصنيفها، و الحكم على صحتها، وتوظيفها لاتخاذ قر ار الصحيح. ج- يكتب المعلم / المعلمة قائمة معايير للبدائل المتاحة ذات علاقة وثثية بحل المشكلة التي سبق تحديدها. V- يصنف المعلم/ المعلمة البدائل المنوفرة إلى (بديل جيد، بديل غير جيد) ثم تقويم البدائل، واختيار الأكثر فعالية مع تحديد النتائج المترنبة على اختيار كل بديل.

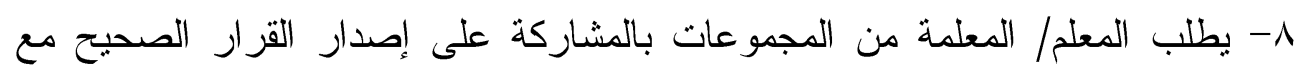

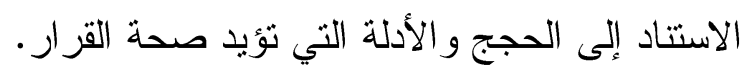
العوامل المؤثرة في عملية اتخاذ القرار

هناك الكثير من العوامل التي تؤثر في اتخاذ القرار، من بينها العوامل الثخصية

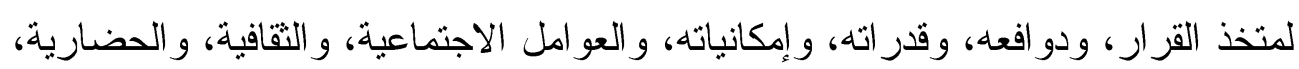


و الاقتصادية، وعامل البيئة و المناخ، و عامل الوقت؛ لأن سرعة التعرف على المشكلة يتيح

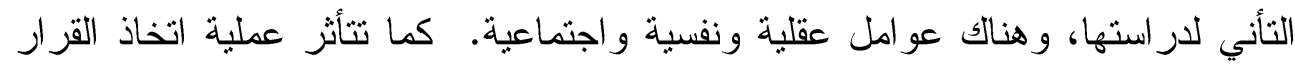

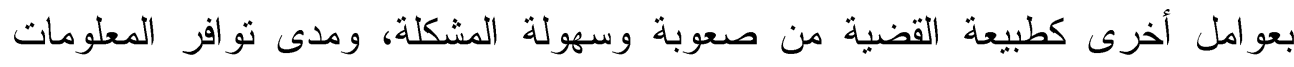
عنها، ومدى قدرة الفرد على المثابرة وتحمل المسئولية، ومخاطرة الأزمات و الأمور

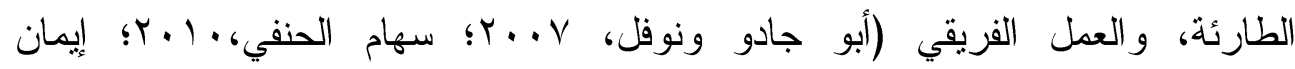

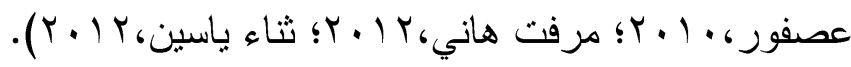

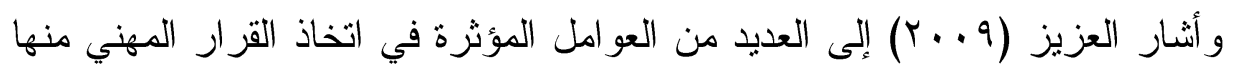
العمر، و الدين، و الجنسية، ومفهوم الفرد لذاته، و عامل الصدفة و الواقعية، وقيم الفرد

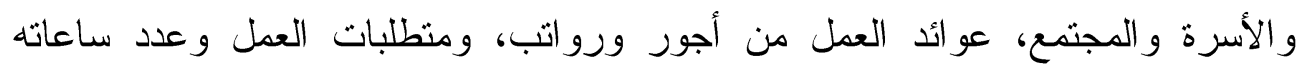

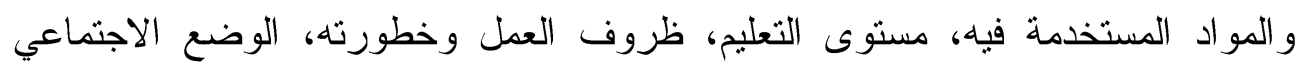
وسمات الفرد الشخصية. وكذلك هناك عو امل مؤثرة في عملية اتخاذ القرار كالثقة الزائدة والرغبة في الأحداث السارية، ورد الفعل، و الميل إلى القرار ات السابقة، وألفة البديل، و المخاطرة،

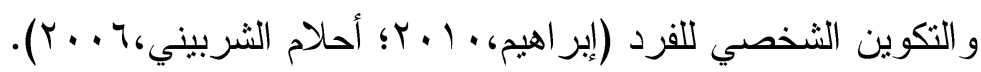

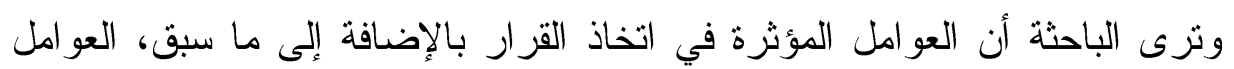
البيئة و العو امل التكنولوجية، الفشل في فهم ابعاد المشكلة، وضعف القيادة و الشخصية

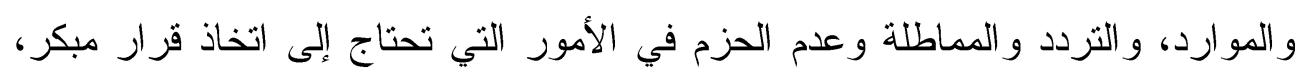

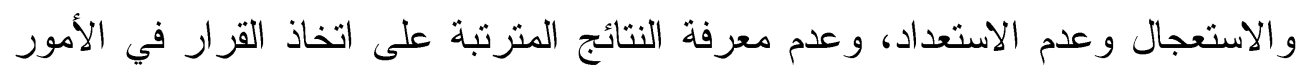
تحتاج إلى الاناة و الحكمة، و الاسنشارة الخاطنئة.

مبادئ اتخاذ القرار الناجح أشار الفقي (• ( • ب) إلى أهم المبادئ لاتخاذ قر اراً ناجحاً، وهي كالآتية:

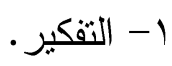

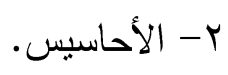

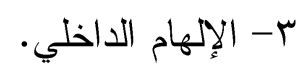
وتزى الباحثة مبادئ اتخاذ القرار الناجح من منظور إسلامي، وهي كالآتي: 
1 - تحديد الغاية: - n

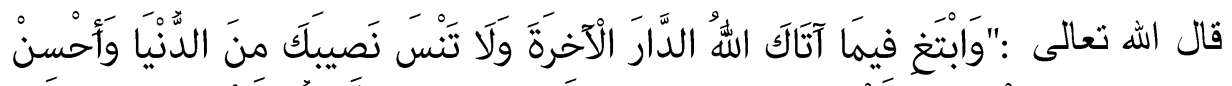

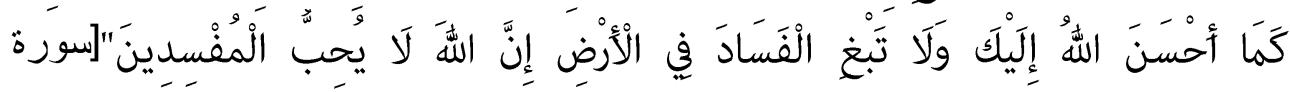
القصص:YV]

نستتنج من الآية الكريمة السابقة من مبادئ اتخاذ القرار الناجح تحديد الغاية العظيمة في إنفاق المال لتحقيق الأهداف الدينية، فييتغ به ما عند الله، ويتصدق وينفق لآخرثه، ولا لانه

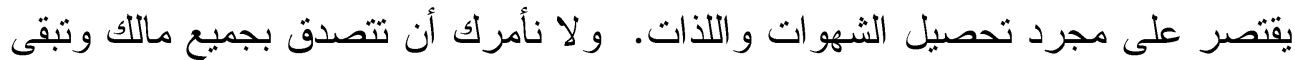

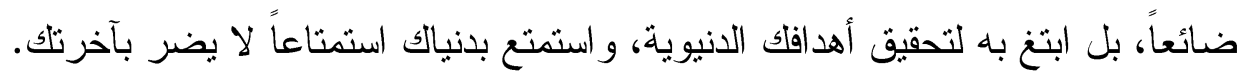

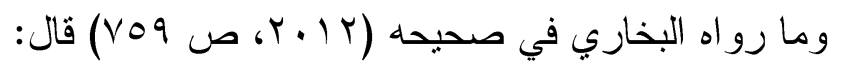

"حدّثنا سليمان بن حرب: حدّثا شعبة، عن عمرو، عن أبي و ائل، عن أبي موسى رضي الله عنه قال: جاء رجل إلى النبي صلى الله عليه وسلم فقال: الرجل يقاتل للمغنم، و الرجل يقاتل للذكر، و الرجل يقاتل ليرى مكانه، فمن في سبيل اله؟ قال: "من قاتل لتكون كلمة الله هي العليا، فهو في سبيل الله". نستتج من الحديث السابق أن من مبادئ اتخاذ القرار الناجح في الجهاد تحديد الغاية العظيمة، وتوضيح الهذف السامٍ من ذلك القتال بأن يكون لإعلاء كلمة التوحيد، وليربأ بنفسه أن يقاتل من أجل غرض ونو دنيوي زائف.

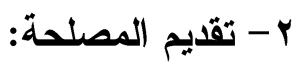

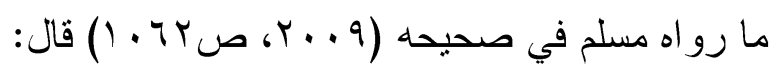

"عن عبداله بن عمرو، قال: جاء رجل إلى النبي صلى الله عليه وسلم، يستأذنه في الجهاد، فقال:" أحي و الدالك ؟" قال : نعم، قال: فقيهما فجاهد". نستتتج من الحديث الشريف السابق أن من مبادئ اتخاذ القرار الناجح في الجهاد تقديم المصلحة، حيث نجد الرسول صلى الله عليه وسلم قدم مصلحة بر الو الدين و العناية بهما عن الجهاد، لأن بر الو الدين أو أحدهما فرض عين، بينما الجهاد فرض كفاية، و إذا تعين

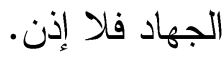

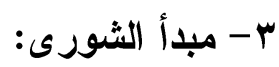




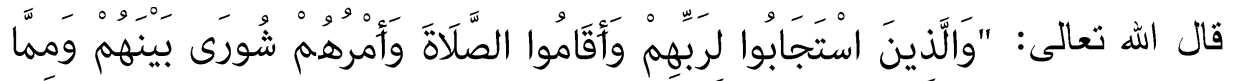

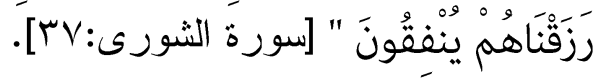
نستتنج من الآية الكريمة السابقة أن من مبادئ اتخاذ القرار الناجح الاستشارة في

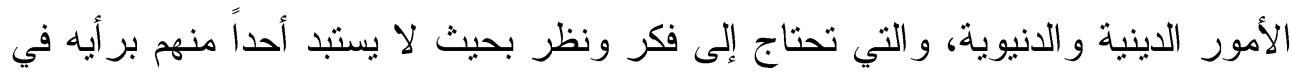
أمر مشترك بينهم، كالغزو و الجهاد وتولية القضاة وغيرها، وهذا من شأن أولو الألباب.

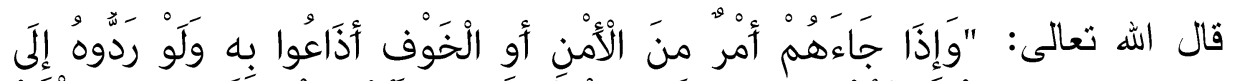

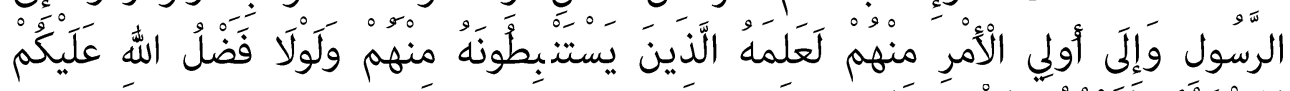

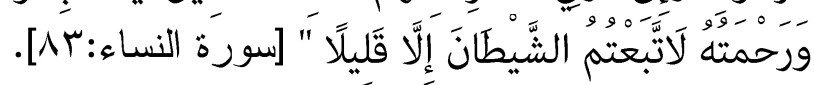

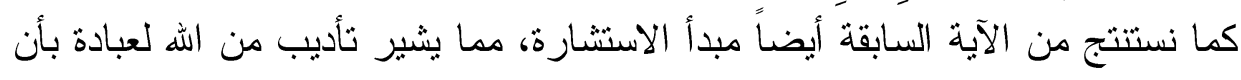

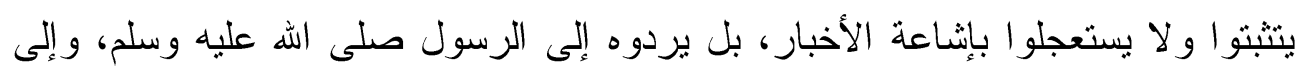
أولى الأمر منهم، و إلى أهل العلم والنصح، و العقل، الذين يعرفون المصالح وضدها. ع - الاعاء أو صلاة الاستخارة:

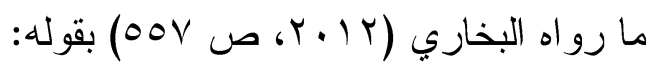
"عن جابر رضي الله عنه فال كان النبي صلى الله عليه وسلم يعلمنا الاستخارة في الأمور كلها كالسورة من القرآن: " إذا هم بالأمر فليركع ركعنين، ثم يقول: اللهم إني أستخيرك لهان

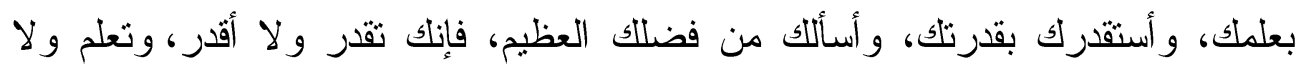

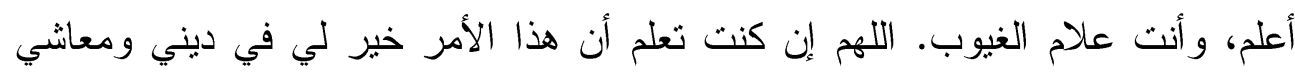

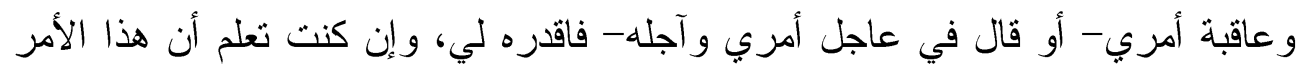

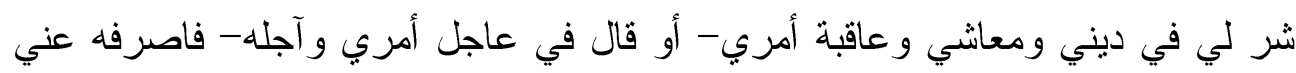
و اصرفني عنه، و اقدر لي الخير حيث كان، ثم رضني وبنه، وينه ويسمي حاجته". نستتج من الحديث السابق أن من مبادئ اتخاذ القرار الناجح الاستخارة في جميع الأمور، بطلب المعونة من رب الناس أجمعين في الحصول على المطلوب ونيل المرغوب، مع بذل الأسباب، فقد كتب اله كثير من الأقدار معلقة بدعائه وسؤاله سبحانه وتعالى، ثم الرضا بما كتبه اله له له. ه - أخذ العظة والع تعبرة: 


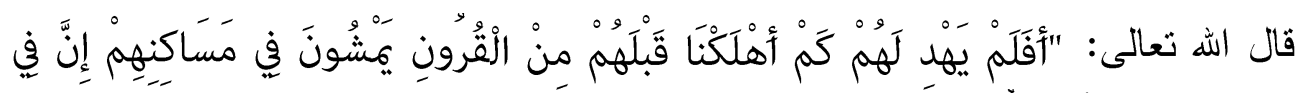

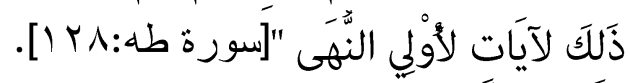

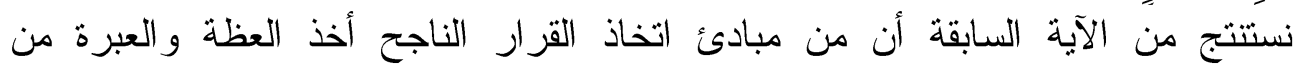

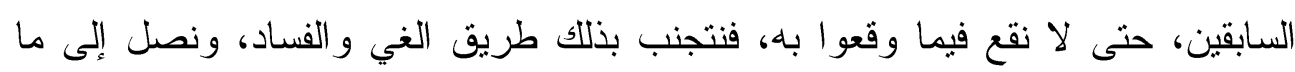
نصبوا إليه "بإذن الله". 1-الحم والأناة:

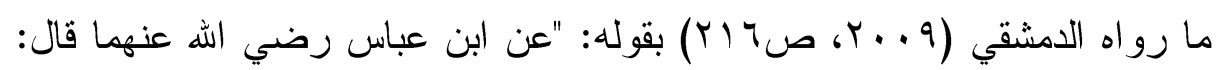

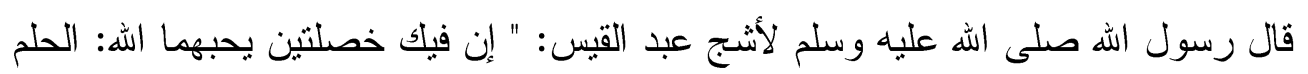
و الأناة".

نستنتج من الحديث السابق أن من مبادئ اتخاذ القرار الناجح التحلي بخصلتين

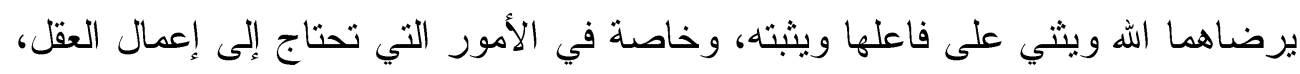

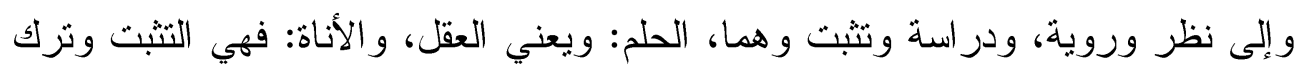

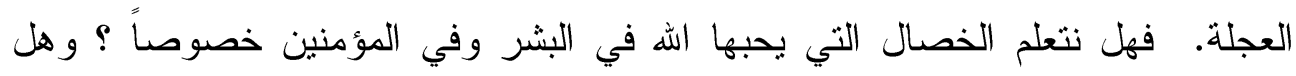
نطبق ذلك في حياتتا وقر ار اتتا الحياتية، ومصير أمتنا؟. v- التوكل وحسن الظن بالله:

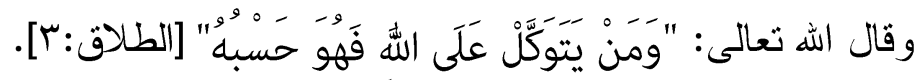

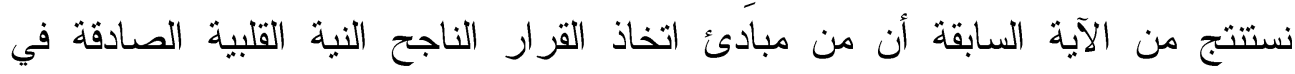

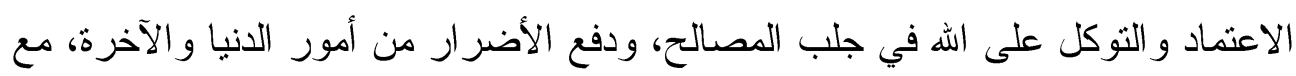

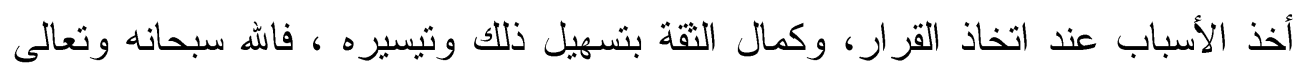
كافيه الأمر الذي توكل علبه به.

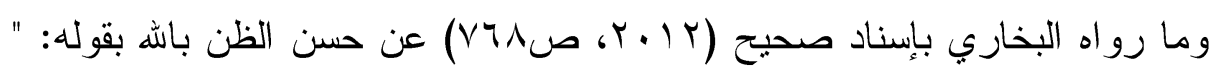

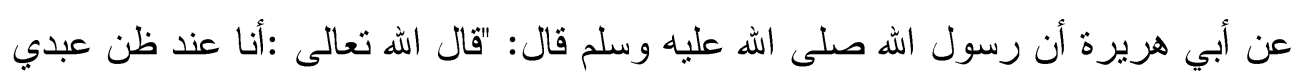
بي". 
نستتنج من الحديث القدسي السابق أن من مبادئ اتخاذ القرار الناجح بعد التوكل على الله في اتخاذ قراره، حسن الظن به عز وجل بأنه لا يضيع عمله ولا ويخيب أمله، فإذا ظن أن الله سيعينه على اتخاذ القرار الصحيح فإن الله يعينه على ذلك. بله

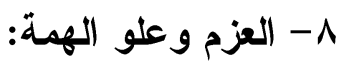

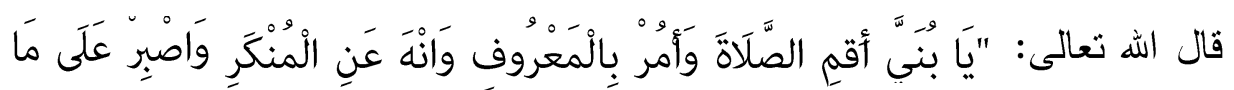

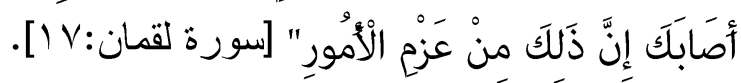

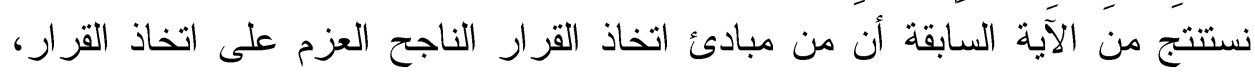

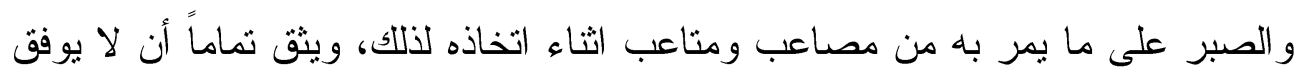

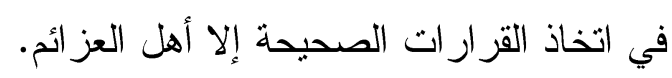
أشنار الندوي (9 . . Y،صع Y T) إلى على همة الرسول صلى الله عليه وسلم و اتخاذ قر اره بكل عزيمة وثبات بقوله: "ظن رسول الله صلى الله عليه وسلم أن عمه أبا طالب قد اضطرب في أمره، وضعف

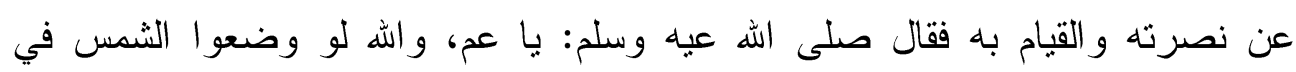
يميني، و القمر في يساري، على أن اترك هذا الأمر حتى يظهزه الله، أو أهلك دونه، ما واله

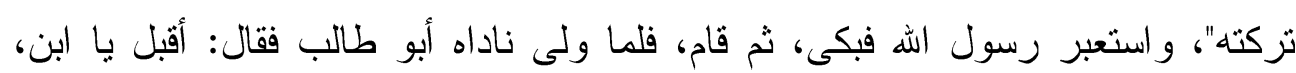

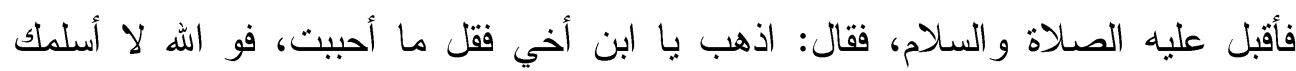
لشيء أبداً" فئر

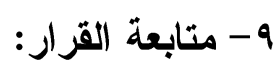

ما رو اه البخاري (Y ( • Y، صـ • O) عن متابعة الرسول صلى الله عليه وسلم لقرار اصدر ه بقو له: - 20 - 20

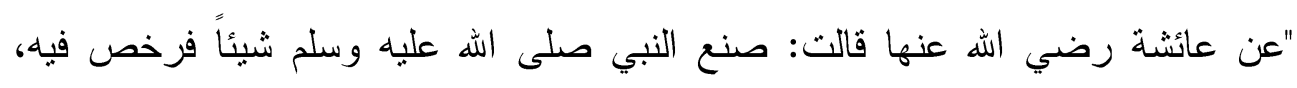
فنتزه عنه قوم، فبلغ ذلك النبي صلى الله عليه وسلم، فخطب فحمد الله ثم قال: " ما بال أقو ام يتنز هون عن الثيء أصنعد؟ فو الله إني لأعلمه بالله و أثندهم له خشية" أهمية تنمية مهار ات اتخاذ القرار لطلبة المرحلة الثانوية 


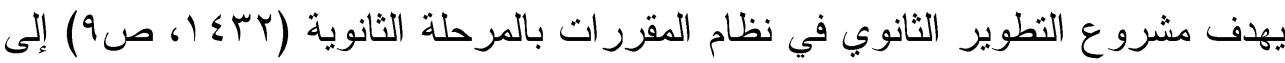
إحداث نقله نوعيه في التعليم الثانوي، بأهدافه، و هياكله، و أساليبه، ومضامينه، ويسعى إلى بلى تحقيق مجموعة من الأهداف، و التي منها الآتي: l - تتمية قدرة الطالب على اتخاذ القرارات الصحيحة المستقبلية، مما يعمق ثقته بنفسه، ويزيد إقباله على المدرسة و التعليم، طالما يدرس بناءً على اختباره ووفق قدر اته، وفي المدرسة التي يريدها. r- إكساب الطالب المهار ات الأساسية التي تمكنه من امتلاك منطلبات الحياة العملية و المهنية من خلال تقديم مقرر ات مهارية بتطلب در استها من قبل مجمو عة من الطلاب. r- تتمية المهار ات الحياتية للطالب: مثل التعلم الذاتي ومهارات التعاون و التو اصل مهل و العمل الجماعي، و التفاعل مع الآخرين، و الحوار و المناقشة.....و غيرها. ع- تطوير مهار ات التعامل مع مصادر التعلم المختلفة و التقنية الحديثة و المعلوماتية وتوظيفها إيجابياً في الحياة العملية. 0ـ تتمية الاتجاهات الإيجابية المنعلقة بحب العمل المهني المنتج، و الإخلاص في

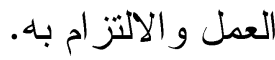
وتشير الباحثة إلى أهمية تنمية مهار به اتخاذ القرار لاى الطلاب/ الطالبات في المرحلة الثانوية، حيث تعتبر من المر احل الهامة في حياتهم؛ لأنها الفترة التي يتم فيها بناء مستقبلهم التعليمي و الوظيفي. كما أنها نعتبر منعطف خطير في حياتهم يحدث فيها تغير ات عضوية، نفسية، وذهنية، ويو اجهون فيها العديد من الأمور و المشكلات، كالتدخين، و الزواج، والطلاق، و الابتعاث، وطريقة التعامل مع الثبكة العنكبوتية...وغيرها من الأمور و المشكلات، بحيث يحتاجون خلالها إلى تتمية مهارات اتخاذ القرار للديهم، وتعويدهم وتوجيههم إلى اقتراح الحلول، و إيجاد أفضل البدائل لمواجهتهم هذه الأمور و المشكلات.

وقد أثثتت بعض الدراسات و البحوث أهمية تتمية مهارات اتخاذ القرار لاى طالب|

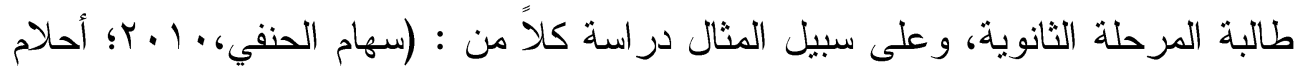

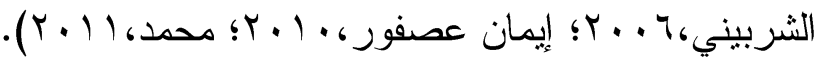


الار اسات السابقة:

\section{دراسات تثاولت تقويم أو تحليل مناهج الثقافة الإسلامية}

تتاول هذا المبحث الدراسات التي تتاولت ثقويم أو تحليل مناهج الثقافة الإسلامية ذات الصلة بالدر اسة الحالية من خلال: هدف الدراسة، ومنهجيتها، و أدو اتها، و أهم النتائج التي لتهاتي توصلت إليها كل در اسة، وفيما يأني عرضاً موجزاً لهذه الدر اسات:

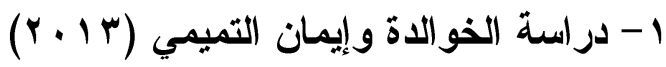

هدفت هذه الدراسة إلى تقويم جودة كتب الثقافة الإسلامية للمرحلة الثانوية في ضوء معايير الجودة المعتمدة من وزارة التزبية و التعليم في الأردن. تكون مجتمع الدراسة الإسلة و عينتها من جميع كتب الثقافة الإسلامية للمرحلة الثانوية بمستوياته الثلاثة للصفوف الأول، و الثاني الثانوي الثامل. استخدمت الدراسة منهج تحليل المحتوى وقائمة تحليل اشتملت على سبعة مجالات وتسعة و أربعون فقرة تم التحقق من صدقها وثباتها بالطرق المعهودة. وكان من أبرز نتائج الدراسة: احتل مجال المعايير الفنية للكتاب المرتبة الأولى بين المجالات في الكتابين، بينما احتل مجال معايير الأنشطة التعليمية المرتبة الأخيرة. كما أن درجة تطبيق هذه المعايير في الكتابين جاءت بدرجة كبيرة ومتوسطة.

$$
\text { r }
$$

هدفت هذه الدراسة إلى تقييم كتب الثقافة الإسلامية في الأردن في ضوء الأهداف التي تحقق الضرورات الخمس. تكونت عينة الدراسة من كتب الثقافة الإسلامية في المرحلة الثانوية في الأردن، استخدمت الدراسة المنهج الوصفي التحليلي، و استخدمت أداة قياس وتحليل اشنملت على خمسة محاور و اثثين وأربعين معيار اً، وتم تحقق الصدق و الثبات لهما. وقد كشفت نتائج الدراسة عن ارتفاع نسبة مر اعاة كتب الثقافة الإسلامية للمحور الأول وهو حفظ الدين، في حين جاءت نسبة مراعاة الأهداف التي تحقق المجالات الأخرى" حفظ النفس، حفظ المال، حفظ العرض، حفظ العقل" متدنية جداً. r- در اسة آل شعلان (ب ع ع 1) هدفت هذه الدراسة إلى تحديد حاجات ومشكلات طلاب المرحلة الثانوية في المملكة العربية السعودية. وترتيب هذه الحاجات و المشكلات حسب أهميتها من وجهة نظر 
الطلاب و المعلمين. وتحديد تو افر هذه الحاجات و المشكلات في مقرر الحديث و الثقافة الإسلامية للمرحلة الثانوية. وبناء تصور مقترح لنطوير منهج الحديث و الثقافة الإسلامية

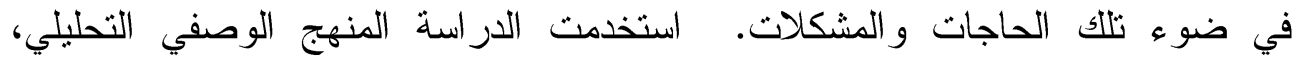
وتكونت عينة البحث من طلاب المرحلة الثانوية نظام المقررات وبلغ عددهم (90؟)

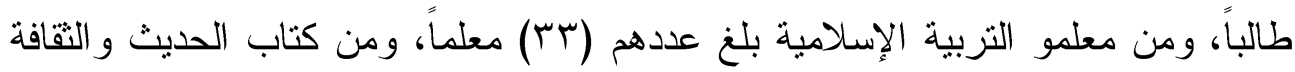
الإسلامية (1) البرنامج المشترك. تكونت أدوات البحث من عأدوات هي استبانتان لقياس الحاجات و المشكلات، وبطاقتان لتحليل المحتوى. وكان من أهم النتائج تم تحديد حاجات الطلاب ومشكلاتهم الو اجب تو افر اها في منهج الحديث و الثقافة الإسلامية، وقد بلغت (ع مان حاجة و (^ا) مشكلة موزعة على (؟) محاور، المحور الأول الروحي و النفسي، المحور الثاني الاجتماعي، و المحور الثالث العقلي و الفكري، و المحور الرابع الجسمي والصحي، و المحور الخامس الأخلاقي، و المحور السادس الاقتصادي و الساسي. ع-در اسة بابية وبابية (11)

هدفت هذه الدر اسة إلى ثقويم أنشطة التعليم والتعلم بمقررات الثقافة الإسلامية في جامعة الطائف على ضوء مبادئ التعليم المتمركز حول الطالب، و اعتمدت الدراسة على الى المنهجين الوصفي التحليلي، والثبة التجريبي، وتكونت عينتها من مقررات الثقافة الإسلامية في جامعة الطائف، و استخدمت أدانين هما: استبانة التحليل لمقررات الثقافة الإسلامية، و استبانة مقياس الاتجاه. وكان من أهم نتائج الدراسة : خلو هذه المقررات تماما من ذكر أي أنشطة تعليم أو تعلم تتمركز حول الطالب ويتزثب على ذلك خلو المعايير، وبغياب الأنشطة في المقررات فلن تظهر أب اتجاهات لطلاب نحوها.

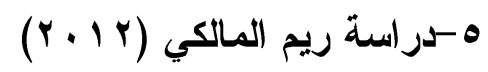

هدفت هذه الدراسة إلى الكثف عن مدى تضمين محتوى مقرر الثقافة الإسلامية في جامعة الطائف للقيم الأخلاقية اللازمة لمواجهة تحديات العولمة الثقافية. و واعتمدت الإن الدراسة على المنهج الوصفي التحليلي، وتكونت عينتها من مقرر الثقافة الإسلامية

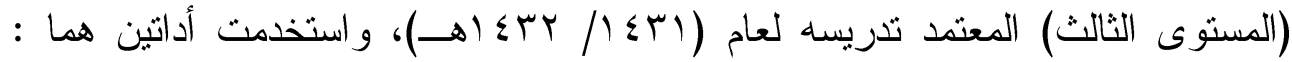
قائمة بالقيم الأخلاقية اللازمة لمو اجهة تحديات العولمة الثقافية، و استمارة تحليل المحتوى. 
وكان من أهم نتائج الدراسة أن محتوى مقرر الثقافة الإسلامية (المستوى الثالث) المقرر

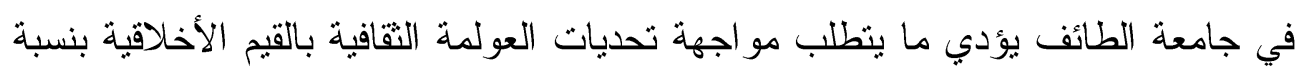
بسيطة.

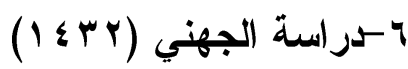

هدفت هذه الدر اسة إلى معرفة درجة احتو اء كتاب الحديث و الثقافة الإسلامية لطلاب الصف الثاني الثانوي على القيم الوسطية، و الى معرفة درجة إسهام كتاب الحديث و الثقافة الإسلامية في تعزيز القيم الوسطية لطلاب الصف الثاني الثانوي في المملكة العربية السعودية، و الكشف عن الفروف الدالة إحصائياً بين التكرارات الخاصة من استجابة عينة الدراسة، واستخدمت الدراسة المنهج الوصفي المسحي، واستخدمت أداتين هما: بطاقة تحليل المحتوى واستبانة للنعرف على آراء مجتمع الاراسة حول إسهام كتب الحديث

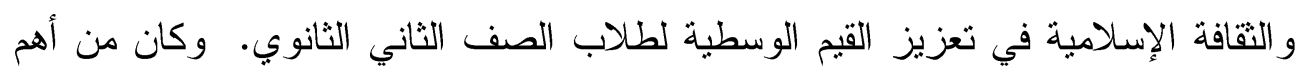
نتائج الدر اسة: احتو اء كتاب الحديث و الثقافة الإسلامية على العديد من المفاهيم التي تعزز

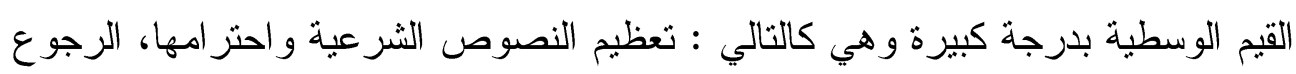

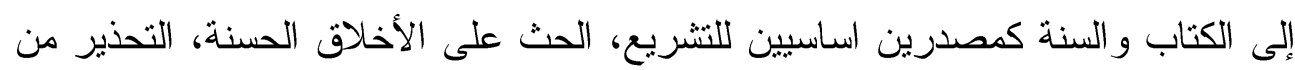

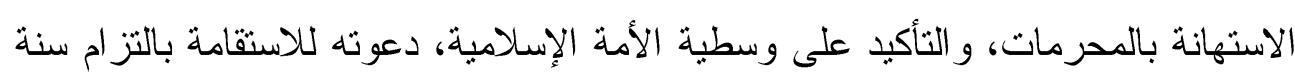
المصطفى (صلى الله عليه وسلم).

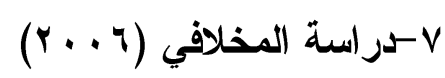

هدفت هذه الدر اسة إلى معرفة مدى وفاء منهج التقافة الإسلامية على طلبة الجامعات اليمنية في تحقيق حاجاتهم ومنطلبات عصر العولمة من الثقافة الإسلامية، واستخدمت الإند

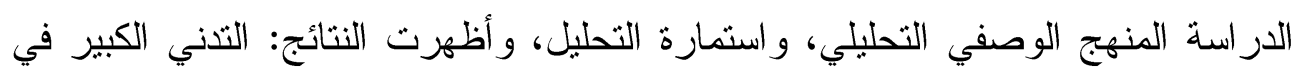
مستوى مراعاة المحتوى الحالي لكتب الثقافة الإسلامية لحاجات الطلبة من الثقافة ونافية الإسلامية، وأن هنالك تذني أكثر في مستوى مراعاة محتوى الكتب لمتطلبات عصر المر العولمة من الثقافية الإسلامية.

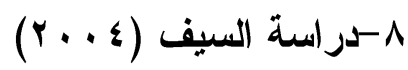


هدفت هذه الدر اسة إلى تحليل محتوى كتب الحديث والثقافة الإسلامية المقرر على طلاب الصف الثالث الثانوي بقسم العلوم الثرعية والعربية بالمملكة العربية السعودية طبعة r ץ إه وذللك بهدف التعرف على مدى تحقيقه لأهداف المرحلة الثانوية في سياسة التعليم في المملكة العربية السعودية، مستخدماً أسلوب تحليل المحتوى، و استخدمت قائمة معايير و التي استخدمت في تحليل المحتوى، ومن أهم نتائج البحث : لم تتحقق البنود الثالية في محتوى كتاب الحديث و الثقافة الإسلامية (موضوع البحث) وهي: البند الثامن/ الوفاء للوطن الإسلامي. البند التاسع/الوفاء للوطن الخاص.

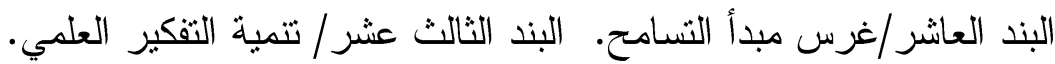

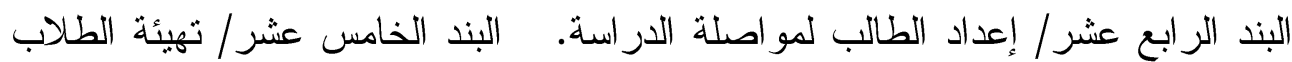
للعمل. البند السادس عشر/ سد حاجة البلاد من المهن المختلفة. البند العشرون/الازدياد من العلم النافع

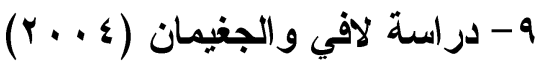

هدفت هذه الدراسة تحليل موضوعات الثقافة الإسلامية بمقر الحديث و الثقافة الإسلامية للصف الثاني الثانوي-قسم العلوم الثرعية العربية-في ضوء احتياجاتهم التعليمية في المملكة العربية السعودية. وتحديد أبرز القضايا المعاصرة المهمة لطلاب الصف الثاني الثانوي، وبناء برنامج في الثقافة الإسلامية يشتمل على أبرز القضايا المعاصرة التي يفتقر إليها مقرر الثقافة الإسلامية لطلاب الصف الثاني الثانوي وقياس أثره في تحصيل الطلاب. و اعتمدت الدراسة على المنهجين الوصفي التحليلي و الشبه التهابه التجريبي، وتكونت عينتها من موضوعات الثقافة الإسلامية في مقرر الحديث و التقافة الإسلامية وطلاب الصف الثاني الثانوي، واستخدمت الأدوات الآتية : قائمة بالقضايا المعاصرة المهمة لطلاب الصف الثاني الثانوي، و استمارة تحليل المحتوى، و اختبار لقياس اثر تحصيل الطلاب. وكان من أهم نتائج الدراسة، عدم وجود فروق دالة إحصائياً بين درجات طلاب المجموعنين التجريبية والضابطة في التطبيق القبلي للاختبار التحصيلي، 
وتفوق المجموعة التجريبية على المجموعة الضابطة في التطبيق البعدي للاختبار

$$
\begin{aligned}
& \text { • التحصيلي }
\end{aligned}
$$

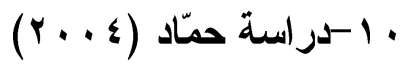

هدفت هذه الدراسة إلى التعرف على القضايا المعاصرة التي تواجه المجتمع الفلسطيني المسلم، وتحليل محتوى مساق الثقافة الإسلامية في الجامعات الفلسطينية، بمحافظة عزة في ضوء القضايا المعاصرة، واعتمدت الدراسة على المنهج الوصفي التحليلي، وتكونت عينتها من محتوى مساق التقافة الإسلامية في الجامعات الفلسطينية، و استخدمت أداتين هما: قائمة بالقضايا المعاصرة، و استمارة تحليل المحتوى. وكان من الإسيان

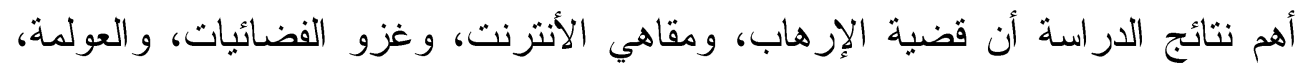

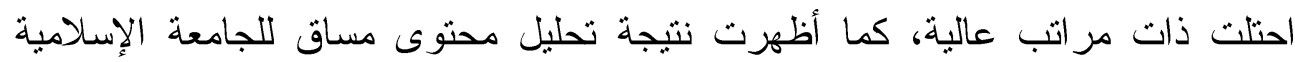
أعلى نسبة في تحقيق القضايا، ثم جامعة القد المفتوحة، ثم جامعة الأقصى.

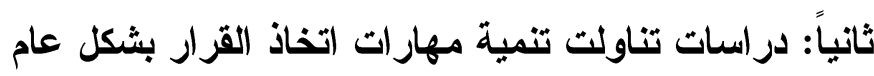

تتاول هذا المبحث الدر اسات التي تتاولت تتمية مهار ات اتخاذ القرار بشكل عام ذات الصلة بالدر اسة الحالية من خلال: هدف الدر اسة، ومنهجيتها، و أدوتها، و أهم النتائج التي لتهات

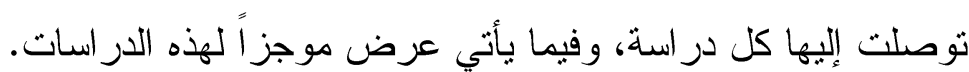

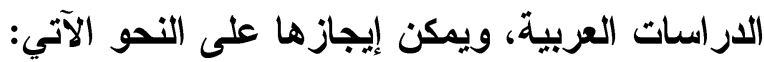

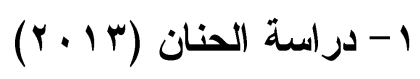

هدفت الدر اسة إلى معرفة استخدام استر اتيجيات التفكير المتشعب في تتمية مهار ات اتخاذ القرار و الوعي التاريخي بتاريخ القدس لدى تلاميذ الصف الثاني إعدادي بجمهورية مصر العربية، معرفة إذا كان يوجد علاقة ارتباطية بينهما، واستخدمت الدراسة المنهجين الوصفي وشبة التجريبي، و استخدمت الدراسة قائمة بمهارات اتخاذ القرار واختبار في إني مهار ات اتخاذ القرار ومقياس الوعي التاريخ بتاريخ القدس لدى تلاميذ الصف الثاني الاعدادي، و أظهرت النتائج : - فاعلية وحدة مقترحة لتدريس التاريخ باستخدام استر اتيجيات التفكير المتشعب في تتمية مهار ات اتخاذ القر ار لدى تلامبذ الصف الثاني الاعدادي. 
- وجود فرق دال إحصائيا بين منوسطي درجات التلاميذ في التطبيق القبلي والبعدي

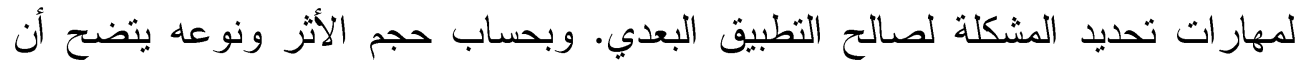
حجم الأثر بلغ (Vq, • ) و أظهر قوة نأثير مرتفعة بلغت (Y,q) ويعد مؤشر مرتفع. - وجود فرق دال إحصائياً بين مثوسطي درجات التلاميذ في التطبيق القبلي و البعدي لمهار ات جمع المعلومات لصالح التطبيق البعدي. وبحساب حجم الأثر ونوعه يتضح أن دهان حجم الأثر بلغ (r, • ·) و أظهر قوة تأثير مرتفعة بلغت (, ؛) ويعد مؤشر مرتفع. - وجود فرف دال إحصائباً بين متوسطي درجات التلاميذ في التطبيق القبلي و البعدي لمهار ات تحديد البدائل لصالح التطبيق البعدي. وبحساب حجم الأثر ونوعه يتضح أن حجم الأثُر بلغ (•V, • ) و أظهر قوة تأثثر مرتفعة بلغت (r) ويعد مؤشر مرتقع. 1- وجود فرق دال إحصائياً بين متوسطي درجات التلاميذ في التطبيق القبلي و البعدي هرئ لمهار ات الاختيار بين البدائل لصالح التطبيق البعدي. وبحساب حجم الأثز ونوعه يتضح

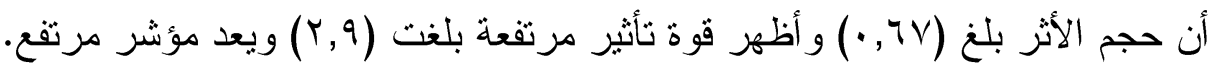
r- وجود فرق دال إحصائياً بين منوسطي درجات التلاميذ في التطبيق القبلي و البعدي لمهار ات إصدار القرار لصالح التطبيق البعدي. وبحساب حجم الأثر ونوعه يتضح أن دان دان حجم الأثر بلغ (VT, · · ) وأظهر قوة تأثثر مرتفعة بلغت (r,r) ويعد مؤشر مرتقع. r- يوجد علاقة ارتباطية دالة إحصائيا عند مستوى (1 .,.•) بين اختبار مهار ات اتخاذ القرار الرئيسة والفرعية ومقياس الوعي الثاريخي بتاريخ القدس عند معامل الارثباط

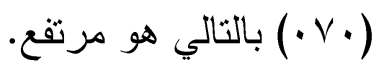

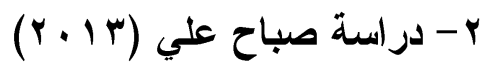

هدفت الدر اسة إلى الوقوف على فاعلية نموذج التحري الجماعي في تتمية مهارات اتخاذ

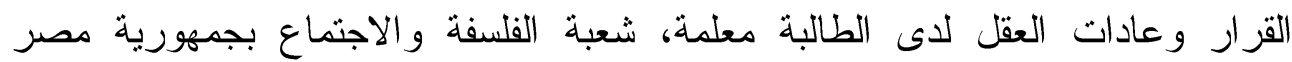
العربية، وتحديد نوع العلاقة الارثباطية بين عادات العقل ومهارات اتخاذ القرار، كما هدفت إلى تحديد القضايا اللازمة للطالبات المعلمات شعبة الفلسفة والاجتماع و التي ترنبط بو اقع المجتمع المصري، واستخدت الدراسة المنهجين الوصفي وشبة تجريبي، 
و استخدمت أدوات قياس تكونت من اختبار عادات العقل (اختبار مو اقف)، ومقياس مهارة اتخاذ القرار من إعداد الباحثة، وكان من أبرز النتائج : 1- وجود فرق ذات دلالة احصائية بين منوسطي درجات الطالبات المعلمات في النطبيق القبلي و البعدي في مقياس اتخاذ القرار لصالح التطبيق البعدي. r- وجود علافة ارتباطية موجبة بين مستوى الطالبات المعلمات في عادات العقل ومهارة اتخاذ القرار، فكلما زاد مستوى العقل لايهن زادت قدرتهن على اتخاذ القرار و العكس

صحيح.

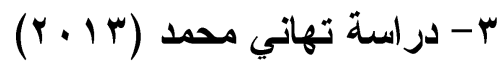

هدفت الدراسة إلى التعرف على فعالية تدريس وحدة مقترحة في الحرب البيولوجية باستخدام مدخل التحليل الاخلاقي في تتمية القدرة على اتخاذ القرار لاى الطلاب المعلمين بكلية التزبية جامعة الزقازيق، و على ابعاد التفكير الأخلاقي المطلوب تتميتها لدى طلاب

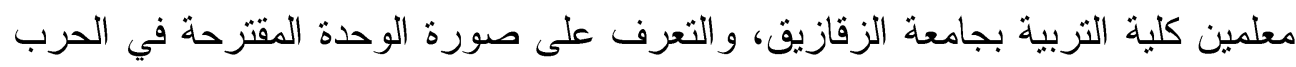
البيولوجية باستخدام مدخل التحليل الاخلاقي، ودر اسة فعالية تدريس هذه الوحدة المقترحة

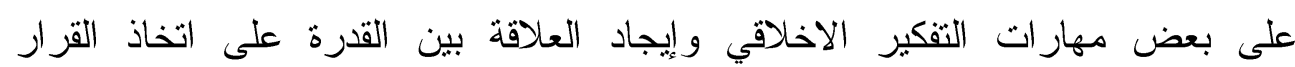
ومهار ات التفكير الاخلاقي، واستخدت الدر ساة المنهجين الوصفي و المنهج شبة تجريبي، واستخدمت الأدوات المتمثلة في اختبار القدرة على اتخاذ القزار، ومقياس التقكير الاخلاقي وكان من أبرز النتائج: 1- وجود فرق ذات دلالة احصائية عند مستوى (1 +. •) بين متوسطي درجات الطلاب

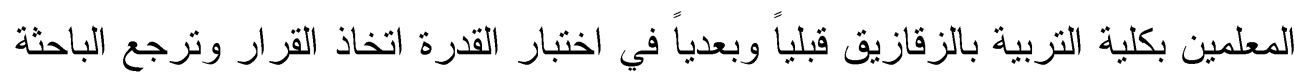
هذه النتيجة إلى توظيف المعلومات بشكل صحيح وتوفير فرص للحوار و المناقشة و البحث و الدر اسة و إعمال العقل في ضوء مجمو عة من المعايير وغير ذلك مما ساعد على القدرة على اتخاذ القزار لدى الطلاب. r- توجد علاقة ارتباطية دالة احصائياً عند مستوى (1 •, •) بين أداء الطلاب المعلمين

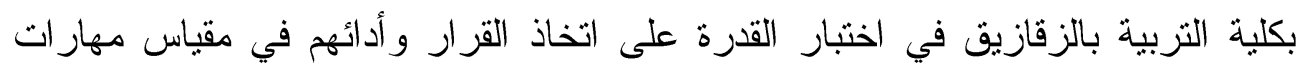

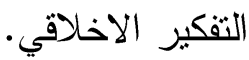




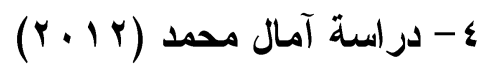

هدفت هذه الدراسة إلى الكشف عن فاعلية برنامج مقترح في تدريس علم الاجتماع

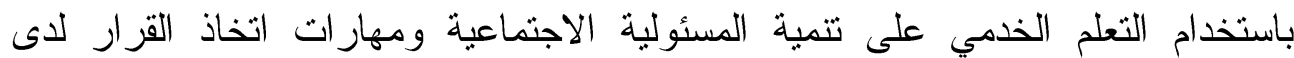
الطلاب المعلمين شعبة الفلسفة والاجنماع بجامعة الفيوم، و استخدمت الدر اسة المنهجين الوصفي التحليلي، و المنهج التجريبي، وشملت أدوات الدراسة على إعداد برنامج مقترح في علم الاجتماع و الفلسفة، و إعداد مقياس المسئولية الاجتماعية، و إعداد اختبار مهار ات اتخاذ القرار، و إعداد مقباس مهارات اتخاذ القرار، وكانت نتائج الدراسة تؤكد فاعلية البرنامج مقترح في تدريس علم الاجتماع باستخدام التعلم الخدمي على تتمية المسئولية الاجتماعية ومهار ات اتخاذ القرار لاى الطلاب المعلمين شعبة الفلسفة و الاجنماع.

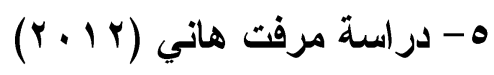

هدفت الدراسة إلى التعرف على فاعلية البرنامج المقترح في تتمية مفاهيم المعلوماتية الحيوية واتخاذ القرار لاى معلمي الأحياء بالتعليم الثانوي بكفر الثيخ، وتحديد المفاهيم

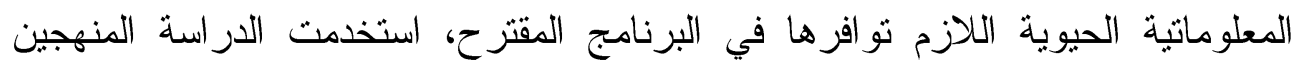

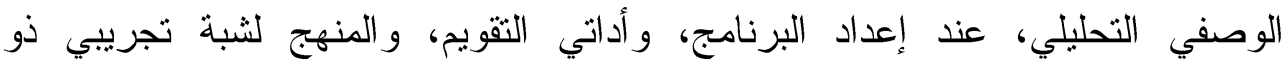

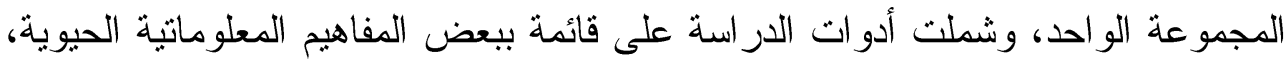
واختبار تحصيلي في المفاهيم المعلوماتية الحيوية، ومقياس اتخاذ القرار في ضوء المعلومانية الحيوية، وبرنامج مقترح في المعلوماتية الحيوية قائم التعلم النشط ، وكان من

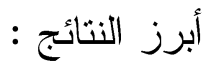
ا-سوجد فرق دال إحصائياً بين منوسطي درجات معلمي الأحياء بالتعليم الثانوي في القياسيين البعدي و القبلي على مقياس اتخاذ القزار لصالح التطبيق البعدي. r- يحقق البرنامج المقترح فاعلية في تتمية اتخاذ القرار لدى معلمي الاحياء بالتعليم الثانوي في ضوء المعلومانية الحيوية. צ- دراسة فتحية لافي (11) هدفت هذه الدراسة إلى الكثف عن مدى فعالية برنامج مقترح في تدريس مادة الثاريخ قائم على عادات العقل لتنمية مهار ات اتخاذ القرار لاى تلاميذ المرحلة الإعدادية 
بجمهورية مصر العربية، واستخدمث الدراسة المنهجين الوصفي، وشبة التجريبي، وشملت أداه الدراسة على مقياس مهار ات اتخاذ القرار، وكانت أبرز نتائج الدراسة : ا- بوجد فرق دال إحصائياً عند مستوى ا ., . بين متوسطي درجات تلاميذ المجموعة

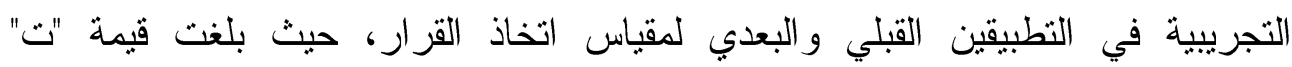

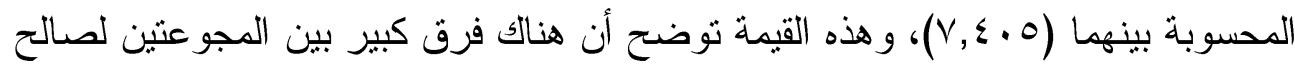
المجمو عة التجريبية. r- يوجد فرق دال إحصائياً عند مستوى ا ., · بين متوسطي درجات تلاميذ المجموعة

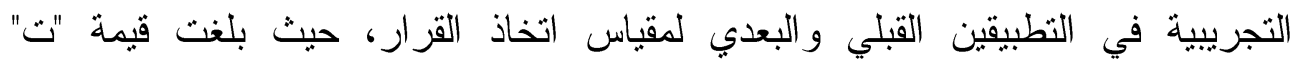
المحسوبة بينهما (·.O,OY)، وهذه القيمة توضح أن هناك فرق كبير بين التطبيقين القبلي و البعدي لمقياس اتخاذ القرار لصالح التطبيق البعدي.

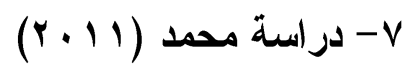
هدفت الدر اسة إلى تقصي فاعلية برنامج مقترح في ضوء البيئة المستحدثة المرتبطة بتطبيقات علم كيمياء لتتمية مهارات اتخاذ القرار حيالها و المكون السلوكي للاتجاهات العلمية لدى طلاب المرحلة الثانوية، استخدمت الدراسة المنهجين الوصفي التحليلي، و المنهج شبة التجريبي، و استخدمت أداتي تكونت ومقياس المكون السلوكي للاتجاهات

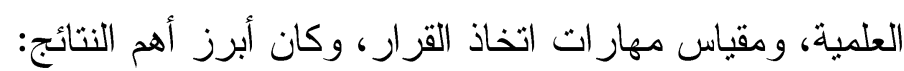

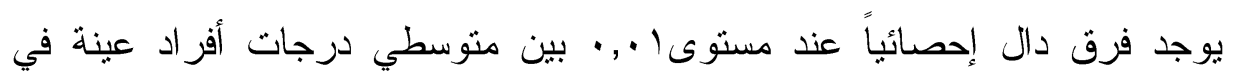

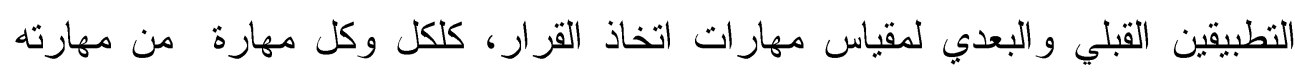
على حدة، لصالح النطبيق البعدي، مما يدل عل أن البرنامج له أثر كبير على تتمية مهار ات اتخاذ القرار لدى عينة الدراسة.

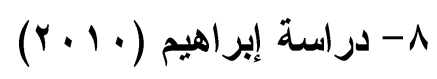

هدفت الدر اسة إلى التحققمن فعالية النموذج التدريسي المقترح في تتمية التفكير الاحتمالي ومهارات اتخاذ القرار لاى تلاميذ المرحلة الابتدائبةبمحافظة بور سعيد، واستخدمت فئه الدراسة المنهج شبة التجريبي، و استخدمت اختباري تمثلت في مستويات التفكير الاحتمالي، وفي مهار ات اتخاذ القرار، وكان من أبرز النتائج : 
يوجد فرق دال إحصائياً عند مستوى (1..,·) بين متوسطي درجات أفراد عينة المجموعة التجريبية و المجموعة الضابطة، في مهارات اتخاذ القرار، لصالح المجموعة التجريبية، بينما لا بوجد فروق دالة في مهارة توليد البدائل، وإن كانت عند مستوى ( $\cdot(\cdot, \cdot)$

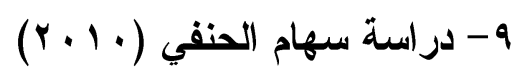

هدفت الدراسة إلى التعرف على فعالية تدريس وحدة في علم الاجتماع باستخدام استر اتيجية حل المشكلات على اكتساب مهار ات اتخاذ القرار لاى طلاب المرحلة الثانوية العامة بجمهورية مصر العربية، و إلى التعرف على فعالية استخدام استز اتيجية حل المشكلات و اتخاذ القرار على تتمية مهار ات اتخاذ القرار و التحصيل، استخدمت الدراسة ولى المنهج شبة التجريبي، و استخدمت أدوات تمثلت في اختبار تحصيل، ومقياس مهارات اتخاذ القرار، وكان من أبرز النتائج: 1- وجود فرق ذات دلالة احصائياً عند مستوى (1 ... •) بين منوسطي درجات طلاب

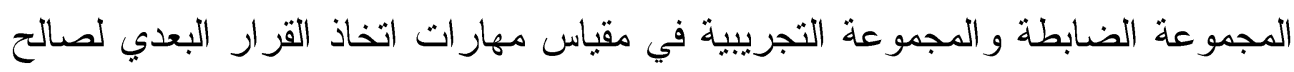
المجموعة التجريبية. حيث بلغ منوسط درجات المجموعة الضابطة للمقياس (9V,Y) بنسبة (^,乏؟ \%) من الدرجة الكلية (.01)، وبلغ منوسط درجات المجموعة التجريبية

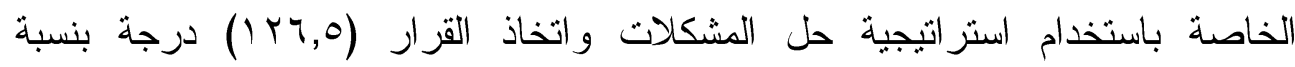

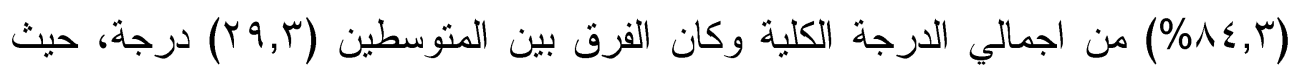

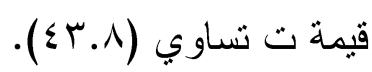
ץ- وجود فرق ذات دلالة احصائياً عند مستوى (1 .,.) بين متوسطات درجات طلاب المجموعة التجريبية في مقياس مهارات اتخاذ القرار البعدي لصالح التطبيق البعدي

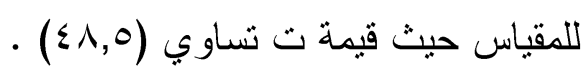

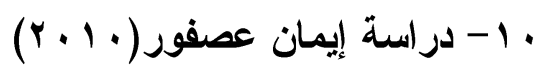

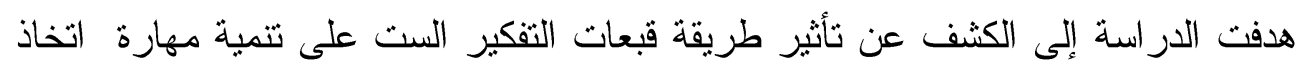

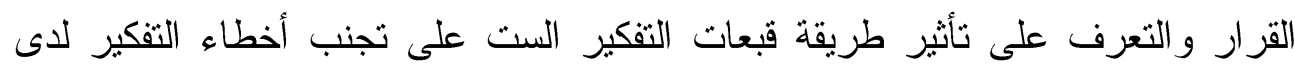
طلاب الصف الثالث الثانوي، استخدمت الدراسة المنهجين الوصفي التحليلي، و المنهج 
التجريبي، واستخدمت أدو ات تكونت من اختبار المو اقف الحياتية، ومقياس اخطاء التفكير،

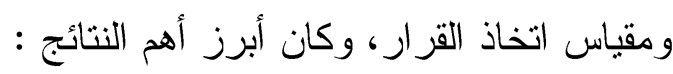
1- أن هناك فرق دال احصائياً بين متوسطي درجات طالبات المجموعتين التجريبية و الضابطة في مقياس اتخاذ القرار ككل وفي أبعاده الفرعية لصالح المجموعة التجريبية.

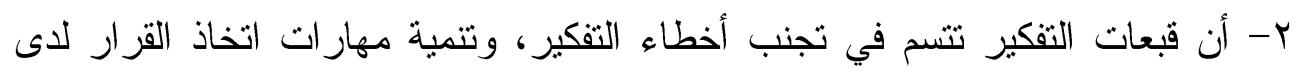
طالبات الصف الثالث الثانوي في مادة علم الاجتماع. ثانياً: الدراسات الأجنبية، ويمكن إيجازها على النحو الآتي:

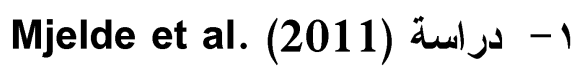

أعدوا در اسة للتحقق من مدى فهم وفعالية تدريس مهار ات صنع القرار الاحتمالية و الأساسية لطلاب المرحلة المتوسطة ولقد هدفت الدراسة إلى معرفة (1) ما إذا كان

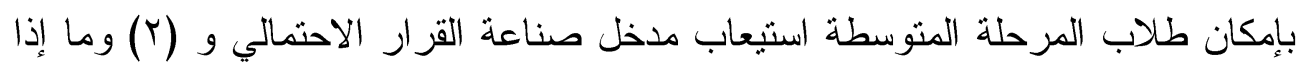
كان تعريض الطلاب لمداخل النمذجة يحسن من قدرات صنع القرار لدى طلاب المرحلة المتوسطة. أوضحت نتائج الدراسة وجود فروق ذات دلالة إحصائية في أداء الطلاب قبلياً

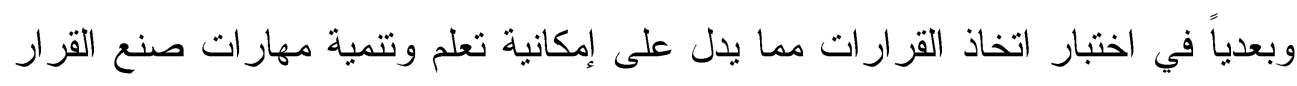
لاى طلاب المرحلة المنوسطة.

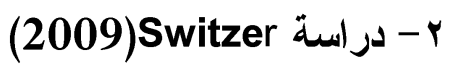

هدفت در استه لتقييم مهار ات صنع القرار البيئية لدى طلاب المرحلة الثانوية وقدم الباحث ثلاث طرق لتقييم مهار ات صنع القزار . ولقد اعتمد الباحث في بنائها على آراء

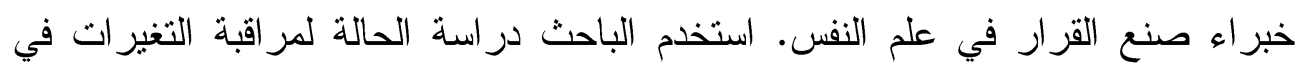

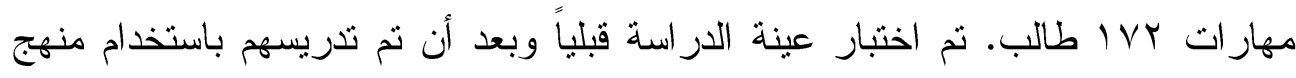

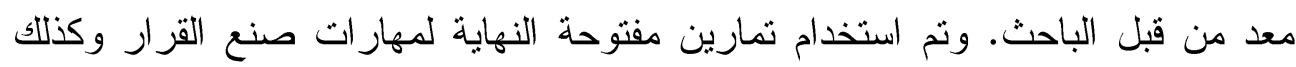
مسحاً للقيم البيئية .أوضحت النتائج أن أساليب التقييم استطاعت الكشف عن مكاسب

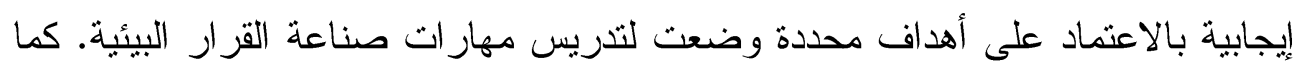
وأن طرق التقييم المقدمة من قبل الباحث من الممكن استخدامها للربط بين طرق وأساليب التقييم و الأهداف التعليمية. 
Rowland (2004) ب- دراسة

هدفت در استه لمعرفة مستوى الثقة في عملية صنع القرار ات المهنية لدى مر اهقين المرحلة الثانوية في مدينة ناساو في جزر البهاما كما هدفت لمعرفة العو امل المؤثزة في هي هرئ مستوى الثقة المتعلق بعملية صنع القرار المهنية لدى المراهقين. ثم توزيع مقياس اتخاذ القرار المهني جنبا إلى جنب مع المسح الديموغر افي إلى میى طالب من طلاب الصف 1 ا و ال Y ا لدراسة ستة عو امل تؤثر على مستوى الثقة في عملية اتخاذ القرارات المهنية. تم استخدام MANOVAS و الإحصاءات المناسبة التبعية لتحديد الاختلافات و التفاعلات المؤثرة بين المتغيرات لقياس مستوى مهارات اتخاذ القرارات المهنية. خلصت الدر اسة إلى أنه بالنسبة للمر اهقين في جزر البهاما، فإن نوع المدرسة، ومستوى

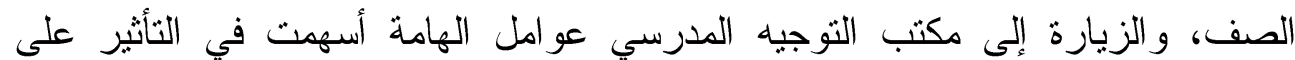
مستوى الثقة للأشخاص بالنسبة لعملية اتخاذ القرارات المهنية. التعقيب على الار اسات السابقة تتاول هذا المبحث التعقيب على الدراسات السابقة، وعلاقتها بالدراسة الحالية. ومدى الاستفادة وموقعها من هذه الدر اسات، وفيما يأني عرضاً موجز أ لهذا التعقيب : أولاً- الار اسات تناولت تقويم أو تحليل مناهج الثقافة الإسدلامية: من خلال العرض السابق للاراسات التي تتاولت تقويم أو تحليل مناهج الثقافة الإسلامية، ذات الصلة بموضوع الدراسة الحالية، أمكن التوصل إلى أوجه نشابه والاختلاف بينهما في العديد من الأمور المتعلقة، يمكن توضيحها في الآتي : ا - من حيث الموضوع و اللهدف : لاحظت الباحثة من خلال اطلاعها على دراسات وبحوث المبحث الأول (المتعلقة بتقويم أو تحليل مقررات الثقافة الإسلامية ) أن بعضها اتفقت على تقويم وتطوير مناهج الثقافة

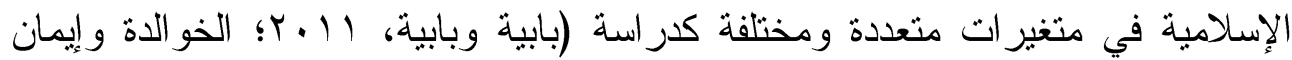

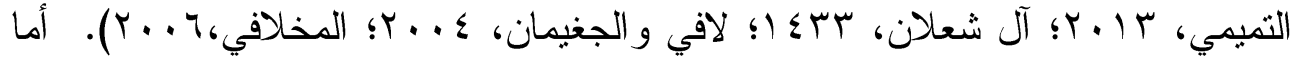
البعض الآخر اتفقت على تحليل وتقييم مناهج الثقافة الإسلامية في منغيرات متعددة

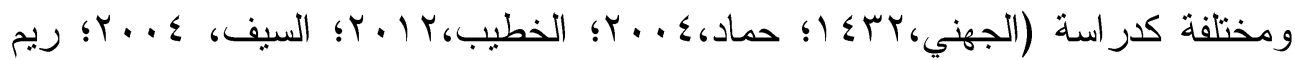




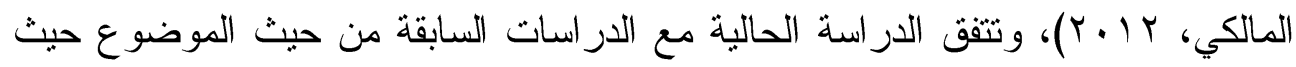
تتاولت ثقويم مناهج الثقافة الإسلامية. ولوحظ التتوع في أهداف دراسات في هذا المبحث، إذ هدف بعضها إلى تحليل وتقويم مقررات الثقافة الإسلامية في ضوء بعض مشكلات الطلاب و احتياجاتهم التعليمية

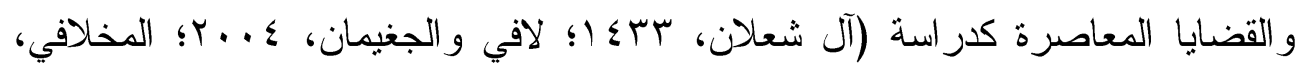

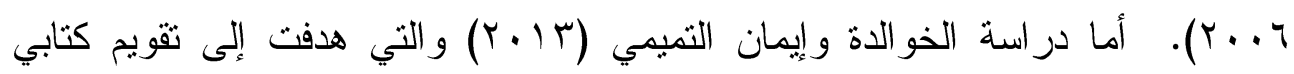

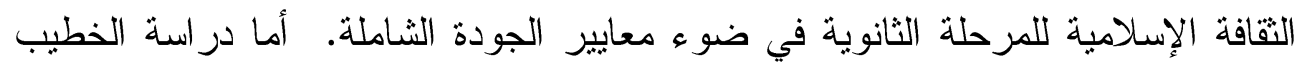

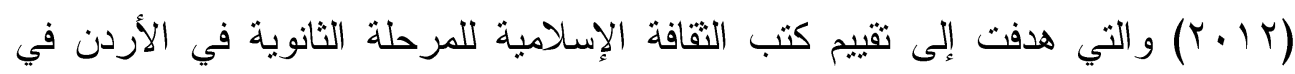

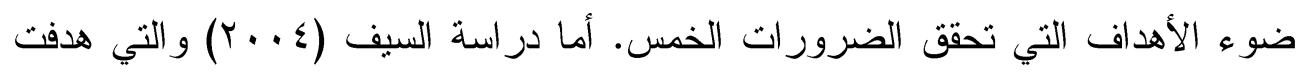
إلى تحليل محتوى كتاب الحديث و الثقافة الإسلامية لطلاب الصف الثالث الثانوي في ولي ضوء أهداف سياسة التعليم في المملكة العربية السعودية.

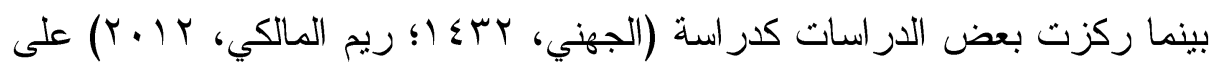
تعزيز بعض القيم ومدى تضمينها في مقررات الثقافة الإسلامية. أما در اسة بابية وبابية

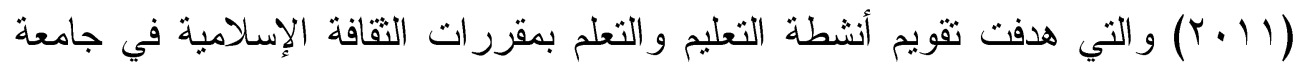

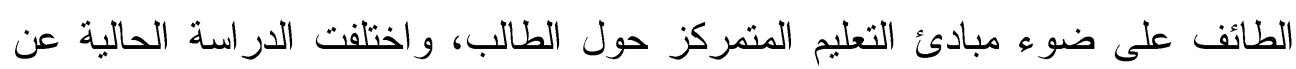
در اسات هذا المبحث باستهدافها ثقويم مقررات الثقافة الإسلامية للمرحلة الثانوية في ضوء

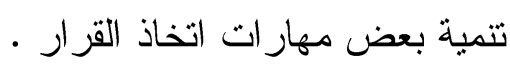
r - من حيث المنهجية: لاحظت الباحثة استخدام معظم دراسات وبحوث هذا المبحث المنهج الوصفي

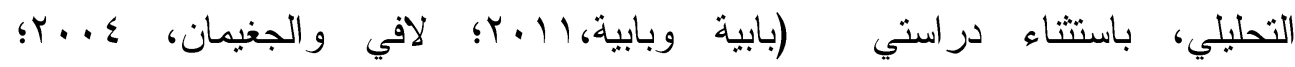

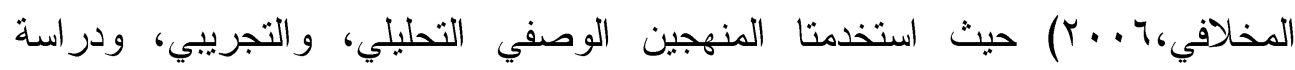

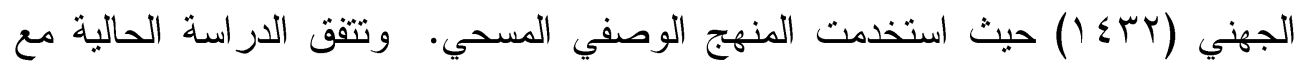
الدراسات التي استخدمت المنهج الوصفي التحليلي.

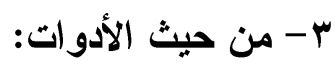


استخدمت أكثر دراسات وبحوث هذا المبحث استمارة تحليل المحتوى، باستثناء در اسة الجني (Y I I ) التي استخدمت أداة الاستبيان بالإضافة إلى استخدامها إلى بطاقة

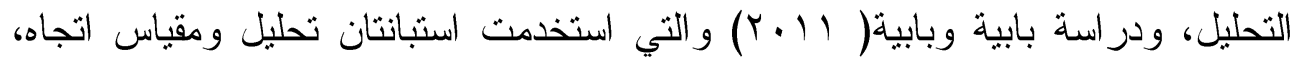
ودراسة آل شعلان (سTع () و التي استخدمت اربع أدوات، استبانتان لقياس الحاجات و المشكلات، وبطاقتان تحليل محتوى، ودر اسة المخلافي (؟ . . ץ) و التي استخدمت بطاقة التحليل ومقياس اتجاه، وبذلك تتفق الدراسة الحالية مع الدراسات التي استخدمت استمارة تحليل المحتوى.

ع - من حيث المرحلة العمرية:

لوحظ أن معظم دراسات وبحوث هذا المبحث طبقت على مقررات النقافة الإسلامية في المرحلة الثانوية في التعليم العام، باستثناء در اسة آل شعلان (سب؟ ()، حيث طبقت على مقررات الثقافة الإسلامية في التعليم الثانوي (نظام المقررات)، ودراسة كل من بن باءه

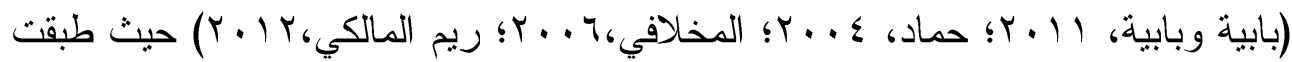
على مقررات الثقافة الإسلامية للمرحلة الجامعية. وتتفق الدراسة الحالية مع دراسة آل

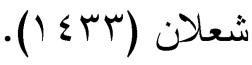

أوجه الاستفادة من البحوث والار اسات السابقة: استفادت الدر اسة الحالية من دراسات وبحوث هذا المبحث، في تحديد المشكلة والتي

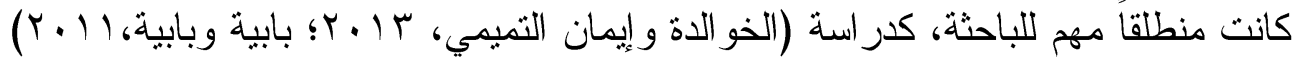
و التي أوصت بالاهتمام بمجال الأنشطة التعليمية التي ثراعي حاجات و اهتمامات وميول الطالب/الطالبة سواء الصفية أو اللاصفية والتي تتمركز حول الطالب في مادة الثقافة الإسلامبة، ودر اسة لافي و الجغيمان (ع . . ب) و التي أوصت بربط مقرر التربية الإسلامية عامة و الثقافة الإسلامية خاصة في المرحلة الثانوية باحتياجات الطلاب، ولثقوية شعورهم بمشكلاتهم ومشكلات مجتمعهم وقضاياها للإسهام في حلها، ودر اسة السيف (ع . . ب) التي أوصت بضرورة تضمين محتوى الثقافة الإسلامية لبعض الموضوعات التي تحقق تتمبة لتهبة التفكير العلمي. 
وقد استفادت الار اسة الحالية من در اسات وبحوث هذا المبحث في تحديد المنهجية

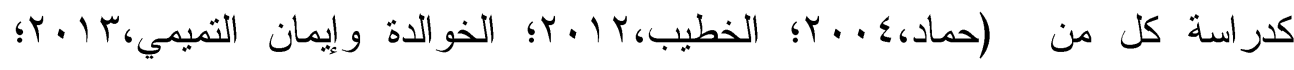

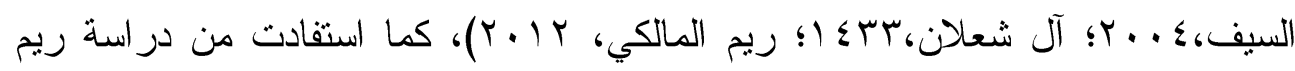

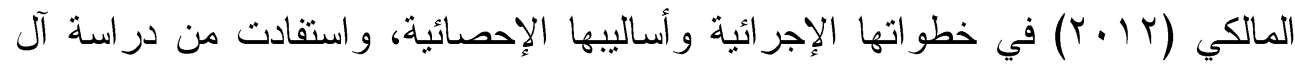
شعلان (س世ء) من إطارها النظري في تحديد مصطلح المرحلة الثانوية،وفي تحديد أهمية تتمية مهار ات اتخاذ القرار لطالب/طالبة المرحلة الثانوية، وفي خطوات بناء

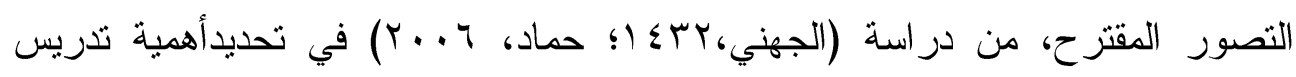
الثقافة الإسلامية، وفي التعرف على خصائص المر اهقين، وحاجاتهم النمائية، حيث بينت

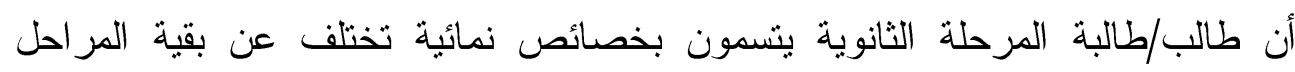
الأخرى.

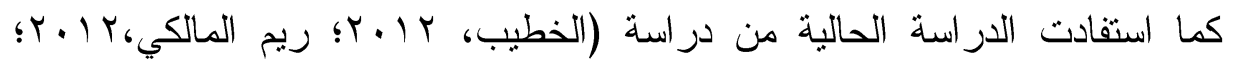
المخلافي، ج . . r ) حيث أمدتها بالعديد من المر اجع و البحوث و الدر اسات السابقة.

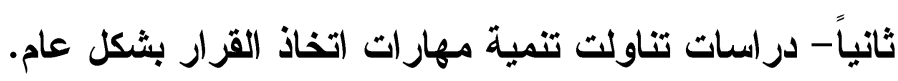

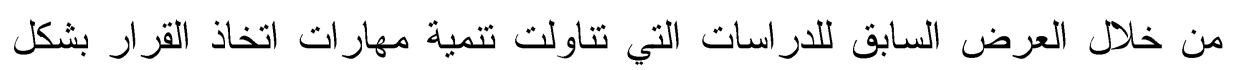

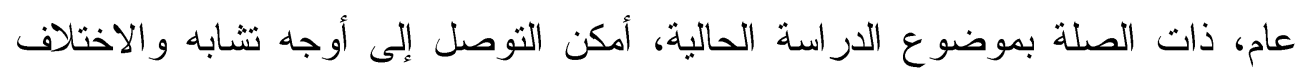
بينهما في العديد من الأمور المتعلقة، يمكن توضيحها في الآتي: ا - من حيث الموضوع و الهدف: لاحظت الباحثة من خلال اطلاعها على در اسات وبحوث المبحث الثاني (المتعلقة

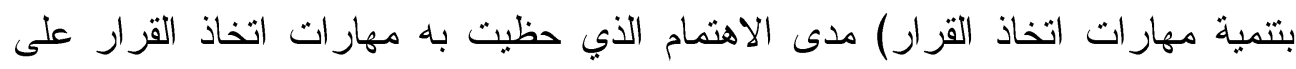

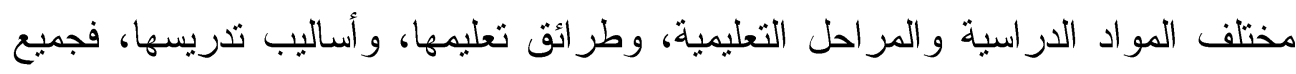

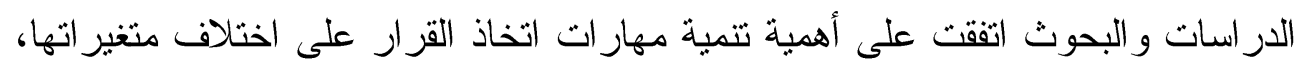
وتتوعت موضو عاتها من بناء بر امج تعليمية، وتقصي أثر استر اتيجيات مختلفة. وتثقق الدر اسة الحالية مع الدر اسات السابقة من حيث الهدف حيث تتاولت الدراسة الحالية ثقويم مناهج الثقافة الإسلامية للمرحلة الثانوية في ضوء تتمية مهار ات اتخاذ القرار 


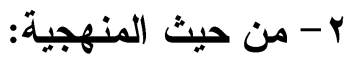

لاحظت الباحثة استخدام معظم در اسات وبحوث هذا المبحث منهجين الوصفي وشبة

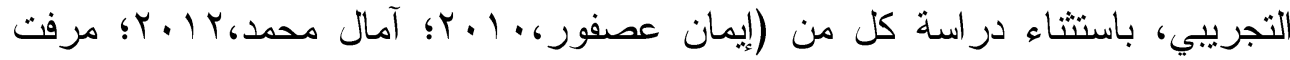
هاني، Y • Y) حيث استخدمت المنهجين الوصفي التحليلي، والتجريبي، ودراسة

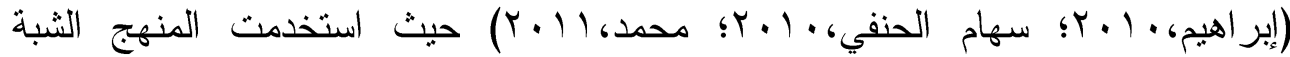
التجريبي، وتثفق الدر اسة الحالية مع الدر اسات التي استخدمت المنهج الوصفي التحليلي.

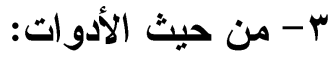
أغلب دراسات وبحوث هذا المبحث استخدمث أدوات قياس واختبار ات و إعداد بر امج

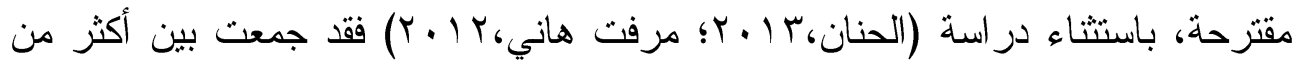

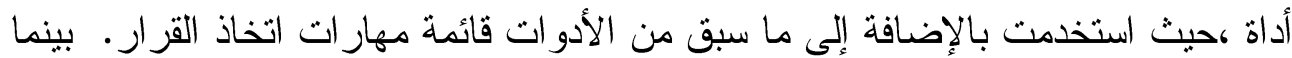
اهتمت دراسات بتتمية مهار ات اتخاذ القرار من خلال مقياس لاتخاذ القرار مثل دراسة مهات

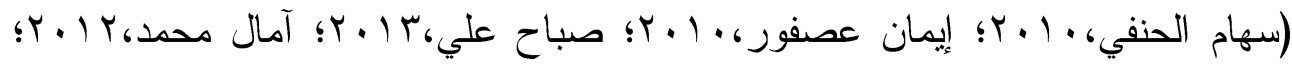

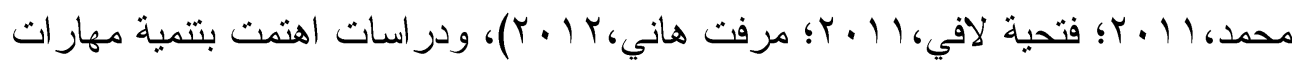

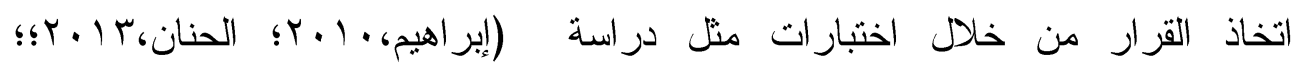

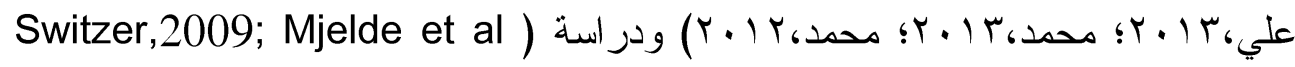

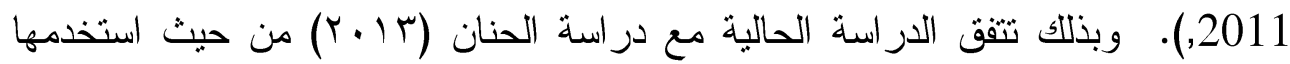
قائمة مهار ات اتخاذ القرار • ومع بقية الدر اسات في إعداد بناء تصور مقترح، باستثناء

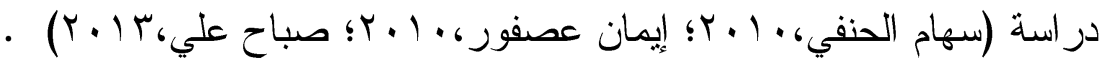
ع - من حيث المرحلة العمرية:

لوحظ أن معظم در اسات وبحوث هذا المبحث طبقت على مقررات ومر احل مختلفة في التعليم العام، لكن أغلبها طبقت على المرحلة الثانوية كدر سة (سهام الحنفي، • ( • ب؛ إيمان

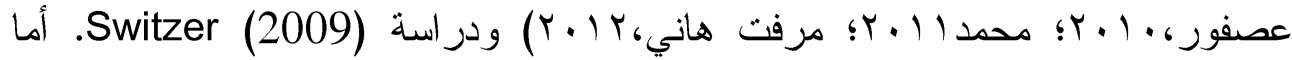

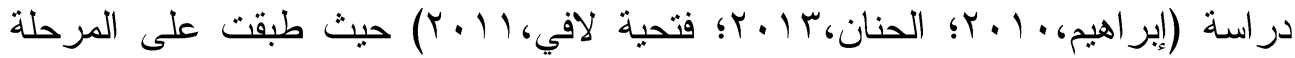

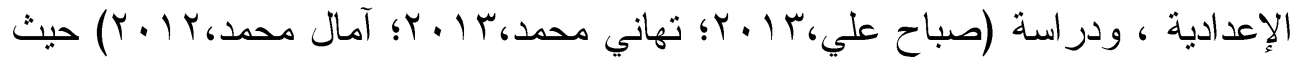
طبقت على المرحلة الجامعية، ودراسة Mjelde et al (2011) طبقت على المرحلة 
المتوسطة. وتثقق الدراسة الحالية مع الدراسات و البحوث التي طبقت على المرحلة الثانوية، وتميزت على بقيه دراسات هذا المبحث بأنها طبقت على التعليم الثانوية (نظام (المقرر ات).

\section{أوجه الاستفادة من البحوث والار اسات السابقة}

استفادت الدراسة الحالية من البحوث و الدراسات السابقة في الإطار النظري في تحديد مصطلح اتخاذ القزار، وخطو اته، وخصائصه، و العلاقة بين عمليتي اتخاذ القرار وحل

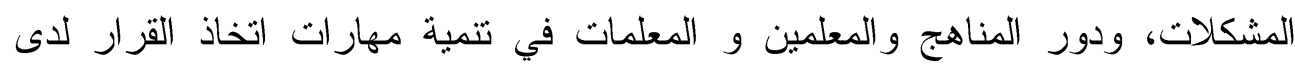
الطلبة، وفي إعداد قائمة بمهار ات اتخاذ القرار ، وفي التوصيات و المقترحات، كما أمدتها بالعديد من المر اجع و البحوث و الدر استهات السابقة. موقع الاراسة الحالية من الار اسات السابقة رغم ما قدمته البحوث و الدراسات السابقة، من إسهامات في تقويم مناهج الثقافة الإسلامية وفي مجال تتمية مهار ات اتخاذ القرار، ومن إفادة الدراسة الحالية منها، إلا أنه لم يتم العثور على دراسة عربية ولا أجنبية، استهدفت الكشف عن مدى تضمين تتمية بعض مهار ات اتخاذ القرار في مقرر الثقافة الإسلامية للمرحلة الثانوية، وذللكهي حدود

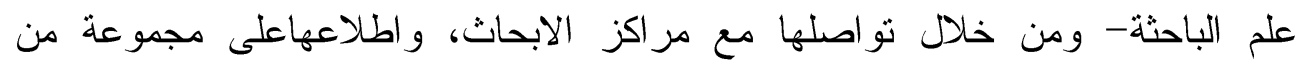

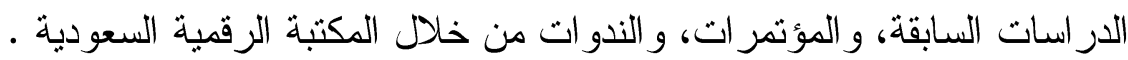

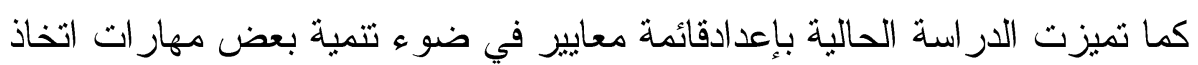

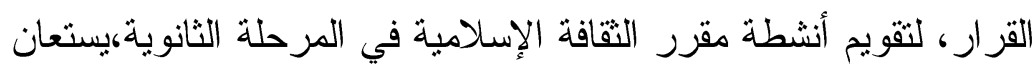
بهافيناءأوتطوير هذه الأنشطة، بحيث تصبح أكثر فاعلية في تتمية بعض مهار ات اتخاذ

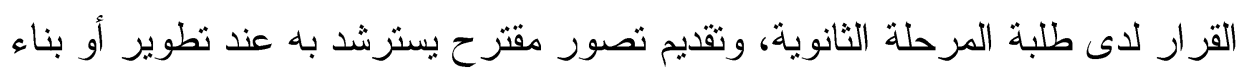

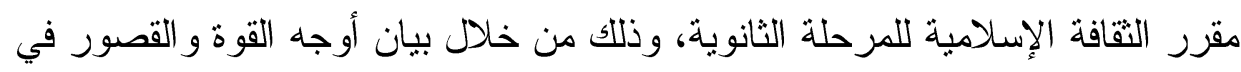
الأنشطة التعليمبة في مقرر الثقافة الإسلامية. عرض نتائج الدراسة وتفسيرها ومناقشتها إجابة السؤال الأول وتفسيره ومناقشته: 
ينص السؤال الأول على: ما مهارات اتخاذ القرار اللازم تضمينها في مقرر الثقافة

الإسلامية للمرحلة الثانوية؟

وللإجابة عن هذا السؤال أعدت الباحثة قائمة بعد الاطلاع على الأدب الثربوي، و البحوث و الدر اسات المتعلقة بمهار ات اتخاذ القرار، حيث اشتثلت على (0) معايير تمثل مهار ات رئيسة، ويحتوي كل معيار على عدد من المؤشرات بلغ مجموعها (ب) مؤشراً، وتم عرضها على عدد من المحكمين، لإبداء آر ائهم حول صلاحية القائمة لهذه الدر اسة، وبعد تحليل آراء المحكمين وملاحظاتهم، و التحقق من ثبات القائمة نم التوصل إلى (0) معايير

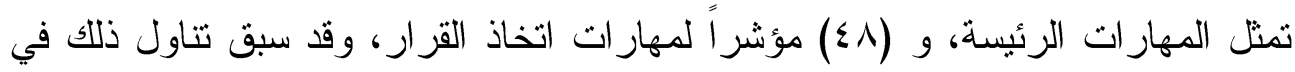
الفصل الثالث (الإجراءات الميدانية)، و المحلق رقم (r) يوضح هذه المهار ات ودرجة اتفاق المحكمين عليها . وبذلك تكون الباحثة قد أجابت على السؤال الأول من أسئلة الدراسة المتعلقة بتنمية مهار ات اتخاذ القرار اللازم تتميتها في مقرر الثقافة الإسلامية للمرحلة الثانوية (نظام

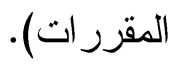
إجابة السؤال الثاني وتفسيره ومناقشته: ينص السؤال الثاني على: ما مدى تضمين مهار ات اتخاذ القرار في مقرر الثقافة الإسلامبة للمرحلة الثانوية ؟ للإجابة عن هذا السؤال فإن الباحثة بعد قيامها و المختصين الآخرين، بتحليل الأنشطة التعليمية الواردة في مقرر الثقافة الإسلامية للمرحلة الثانوية (نظام المقررات)، في ضوء فئات التحليل (مهارات اتخاذ القرار)، ووحدة التحليل (النشاط)، لمعرفة مدى تضمين

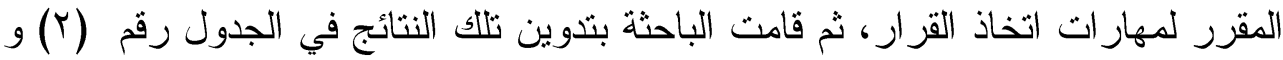
(Y) و (乏) و (0) و (T) و (V)، وتم حساب التكرارات و النسبة المئوية لكل مؤشر من مؤشر ات كل مهارة، ولمجموع مهار ات اتخاذ القرار ككل، وفيما يلي عرض نتائج هذا 


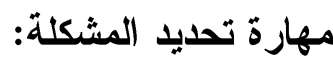

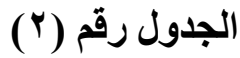

التكرارات والنسب المئوية لمهارة تحديد المشكلة اللازم تضمينها في مقرر الثقافة للمرحلة

الثانوية "نظام المقررات

\begin{tabular}{|c|c|c|c|c|c|c|c|c|c|}
\hline \multicolumn{2}{|c|}{ 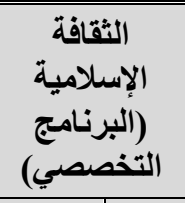 } & \multirow{2}{*}{ 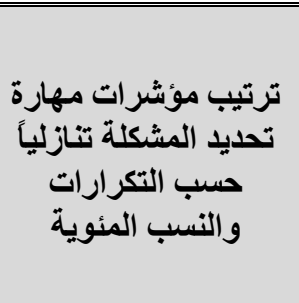 } & \multirow{2}{*}{ 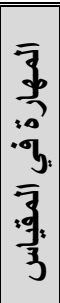 } & \multirow[t]{2}{*}{ 事 } & \multicolumn{2}{|c|}{ الإلبلامية } & \multirow{2}{*}{ 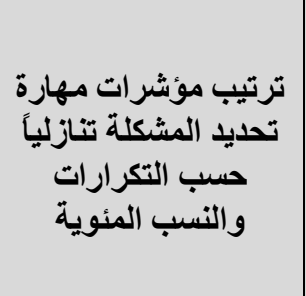 } & \multirow{2}{*}{ 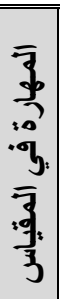 } & \\
\hline 霉事 & 氞 & & & & 兩事 & 氞 & & & \\
\hline $\begin{aligned} 01,17 \\
\%\end{aligned}$ & YY & الإلآلة التي بالمتاج إلى في & 1 & 1 & $\begin{array}{r}0 \cdot, \lambda V \\
\%\end{array}$ & 19 & |الخاذلة التي يحتاج إلى في & & \\
\hline $\begin{array}{r}r v, q . \\
\% \\
\end{array}$ & $T r$ & بالواقع. الاحساس بالمشكلة & $r$ & $r$ & $\begin{array}{r}r,, \wedge \cdot \\
\% \\
\end{array}$ & 14 & بالوبط الإحساس بالمشكلة & $r$ & \\
\hline$\% q, r$ & $\varepsilon$ & المؤثرة في الموامل السلبية. & 9 & $r$ & $\% \wedge, \vee \vee$ & 0 & | تحكلة مأ وردت فياب في & & \\
\hline$\%\urcorner, 9 V$ & $r$ & تمديلة أسباب حدوث في & $\mathrm{v}$ & $\varepsilon$ & $\left.\% 0^{0}, Y\right\}$ & $r$ & | مشكلة ما وريير للار في & $\varepsilon$ & \\
\hline$\%\{, 70$ & $Y$ & تحوئثرة في المشكلة. الإجبية & $\lambda$ & 0 & $0, Y 7$ & $\Gamma$ & 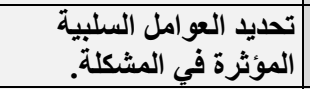 & 9 & \\
\hline$\% \cdot, \cdot$ & $\cdot$ & 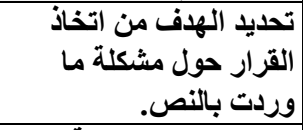 & $r$ & 7 & $\%^{r}, 0$ & T & |تحدئ العوامل الإيجابية & $\lambda$ & \\
\hline$\% \%^{\cdot}, \cdots$ & & مشكلة ما ورديرت في لداسة & $\varepsilon$ & $v$ & , , 0 & 1 & |وقيقاً. المشكلة وصفاً & 0 & \\
\hline $0 \cdot, \cdot \cdot$ & & ويتضفها المشكلة ما & 0 & $\lambda$ & $\% 1, \vee 0$ & $T$ & | تحليل مشكلة ما يتضمنها & 7 & \\
\hline$\% \cdot, \cdots$ & & تحليل مشكلة ما يتضمنها & 7 & 9 & $\% \cdot, \cdots$ & . & 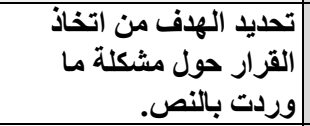 & $r$ & \\
\hline$\% \%^{\cdot}, \cdots$ & & توائجناج). المشكلة (أسباب & 1. & 1. & $\% \cdot, \cdots$ & & 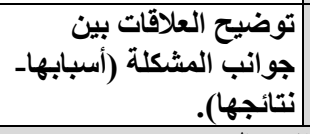 & 1. & \\
\hline & & لإجمالي & & & & & & & \\
\hline
\end{tabular}

يتضح من جدول التكرارات و النسبة المئوية لمؤشرات مهارة تحديد المشكلة اللازم الإمبان تضمينها في مقرر التقافة الإسلامية التعليم الثانوي (نظام المقررات)، أن (·r\%) من 
مؤشر ات مهارة تحديد المشكلة لم ثتضمنها أنشطة البرنامج المشترك، بينما وجد (،ر\%)

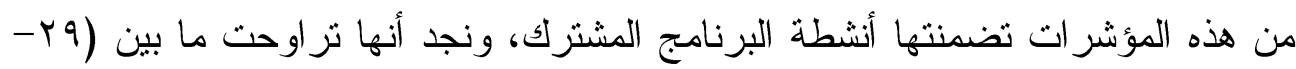

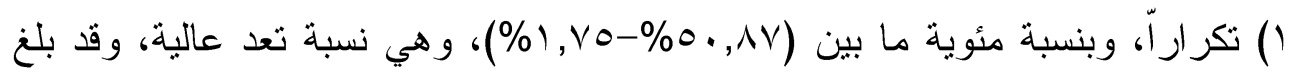

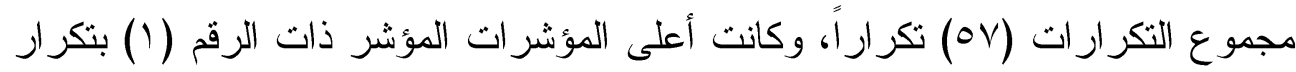

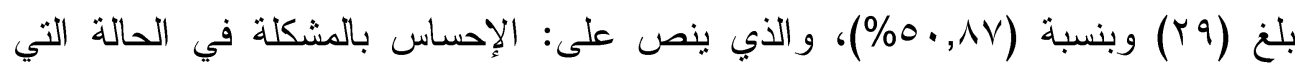

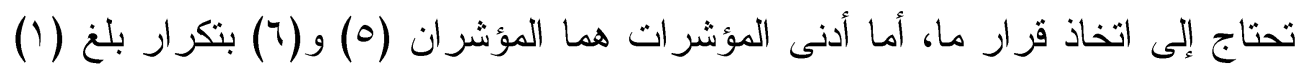
وبنسبة (1,V0) (\%)، واللذان ينصان على التو الي: وصف المشكلة وصفاً دقيقاً، وتحليل

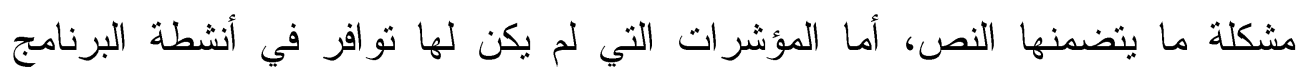

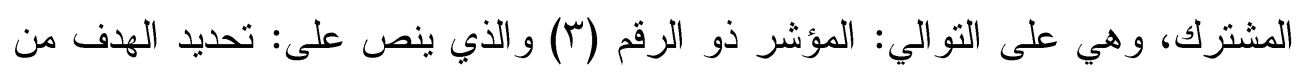

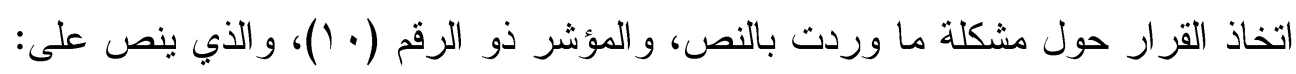
توضيح العلاقات بين جو انب المشكلة (أسبابها-نتائجها). في حين نجد أن (•0\%) من مؤشرات مهارة تحديد المشكلة لم تتضمنها أنشطة

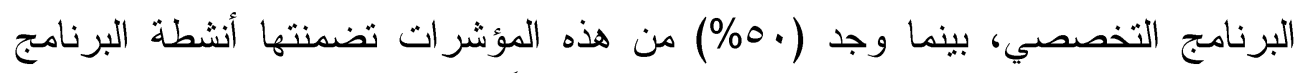

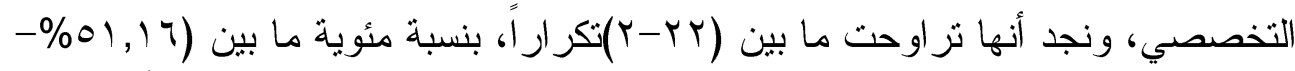

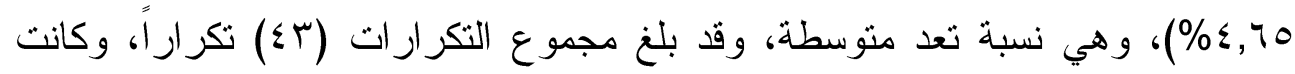

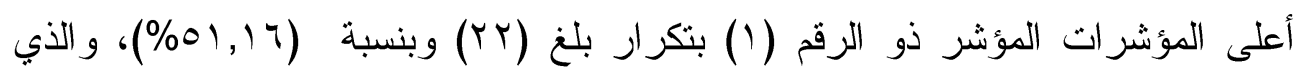

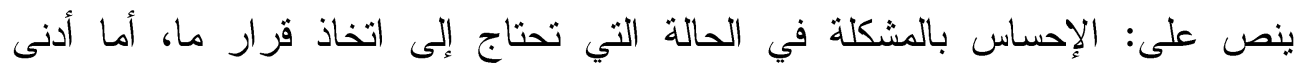

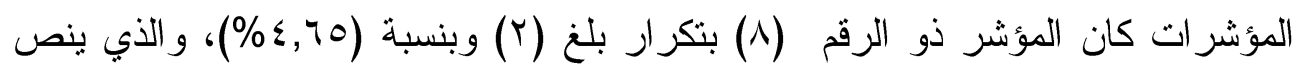

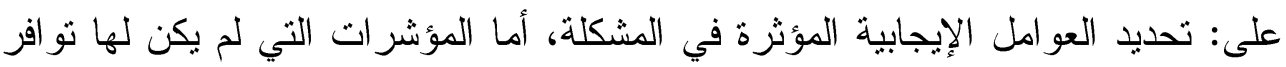

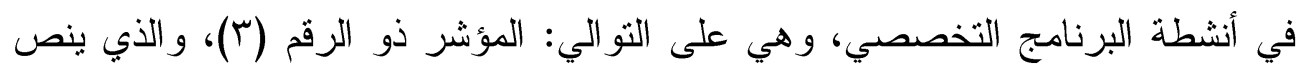

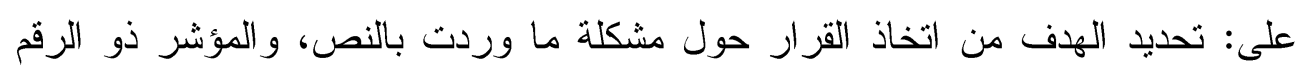

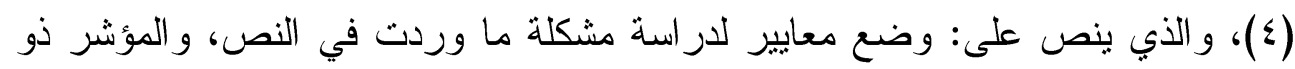

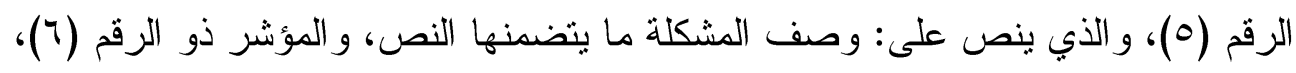

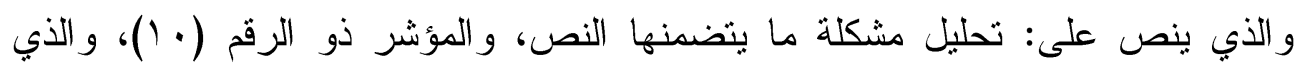
ينص على: توضيح العلاقات بين جو انب المشكلة (أسبابها-نتائجها). 


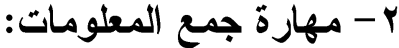

الجدول رقم (r)

التكرارات والنسب المئوية لمهارة جمع المعلومات اللازم تضمينها في مقرر الثقافة للمرحلة الثانوية

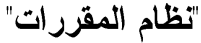

\begin{tabular}{|c|c|c|c|c|c|c|c|c|c|}
\hline \multicolumn{2}{|c|}{ التخصصنيج) } & \multirow{2}{*}{ ترتيب المعولشترات تنازلياً } & \multirow{2}{*}{ 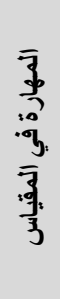 } & \multirow[t]{2}{*}{ 䍂: } & \multicolumn{2}{|c|}{$\begin{array}{c}\text { الثقافة الإسلامئلة } \\
\text { المشترك) }\end{array}$} & \multirow{2}{*}{ 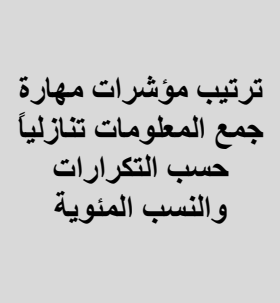 } & \multirow{2}{*}{ 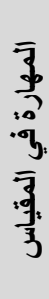 } & \\
\hline 苏事 & 氞 & & & & 牙事 & 氞 & & & \\
\hline $\begin{array}{r}7,11 \\
\%\end{array}$ & 11 & ترتيب المعلومات & V & 1 & $\begin{array}{l}r, \wedge \\
\% 1\end{array}$ & V & ترتيب المعلومات & V & 1 \\
\hline $\begin{array}{r}17,77 \\
\%\end{array}$ & $\Gamma$ & تلى المطلومات. & 1 & $r$ & $\begin{array}{l}r Y, Y \\
\%, r\end{array}$ & 0 & الموجودة في المعلومات. & 7 & $r$ \\
\hline $\begin{array}{r}11,11 \\
\%\end{array}$ & $\bar{r}$ & الموجودة في النصلومات. & 7 & $r$ & $\begin{array}{l}1 \%, 7 \\
\% \pi\end{array}$ & $r$ & تحلى المعلومات . لحصول & 1 & $r$ \\
\hline $\begin{array}{r}11,11 \\
\%\end{array}$ & $\bar{Y}$ & المتوارفة بين المعلومات & 1. & $\varepsilon$ & $\begin{array}{l}1 \%, 7 \\
\% \pi\end{array}$ & $r$ & المتوارنة بين المعلومات & 1. & $\varepsilon$ \\
\hline 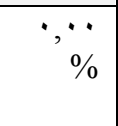 & . & المصلومات المطلوبة في & $r$ & 0 & $\begin{array}{r}9,99 \\
\%\end{array}$ & $r$ & التأكلا من صحة المتواتوة. & 0 & 0 \\
\hline$\cdot, \because$ & $\cdot$ & 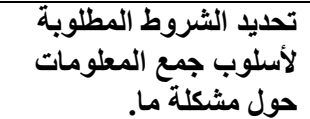 & $r$ & 7 & $\begin{array}{r}9, \cdot 9 \\
\%\end{array}$ & $r$ & التظتيم المعلومات & 1 & 7 \\
\hline $\begin{array}{r}\cdot, \cdots \\
\%\end{array}$ & $\cdot$ & 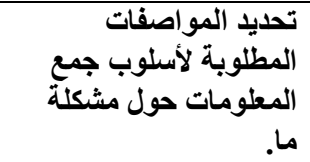 & $\varepsilon$ & $V$ & $\stackrel{י}{\%}$ & $\cdot$ & المصلومات المطلوبة في & $r$ & $\mathrm{~V}$ \\
\hline$\cdot \stackrel{\cdots}{\%}$ & . & التأكل من صحة المعلومات & 0 & $\wedge$ & 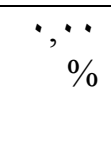 & . & 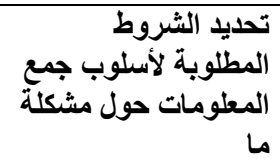 & $r$ & 1 \\
\hline$\stackrel{\cdot \cdots}{\%}$ & . & التظئم المعلومات & $\wedge$ & 9 & $\ddot{\%}$ & $\cdot$ & المطليد المواسلوفات جميع & $\varepsilon$ & 9 \\
\hline$\cdot \stackrel{\cdot \cdots}{\%}$ & • & 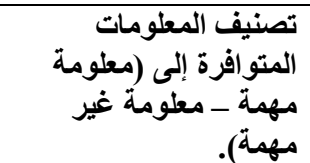 & 9 & 1. & 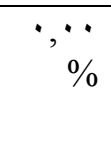 & . & 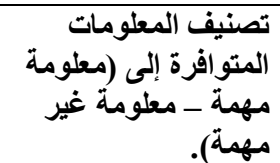 & 9 & 1. \\
\hline$\% 1 \ldots$ & 11 & جموع الإجمالي & & & $01 \ldots$ & $Y Y$ & جموع الإجمالي & & \\
\hline
\end{tabular}


يتضح من جدول التكرارات والنسبة المئوية لمؤشرات مهارة جمع المعلومات اللازم

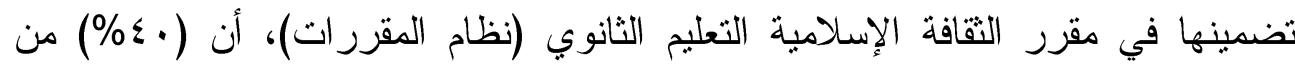

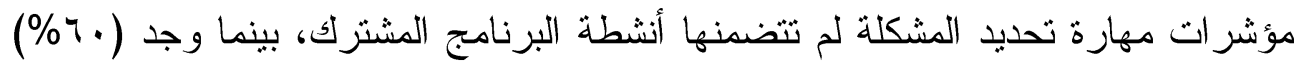

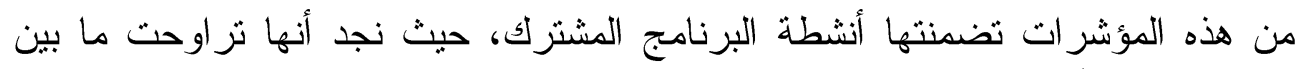

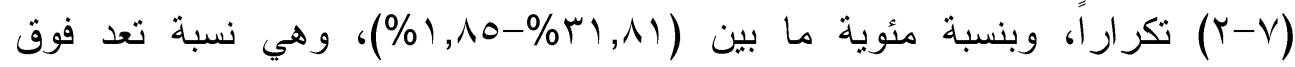

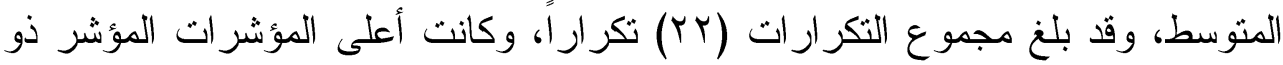

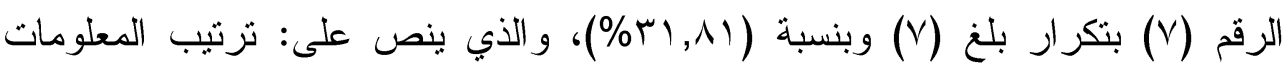

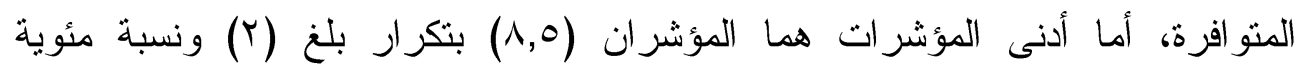
(9 (9\%)، و الذي ينص على: التأكد من صحة المعلومات المتو افرة، وتنظيم المعلومات

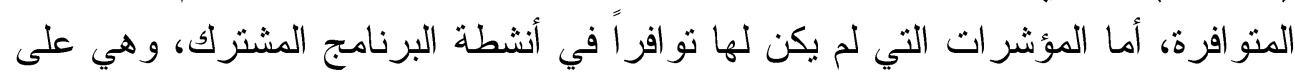

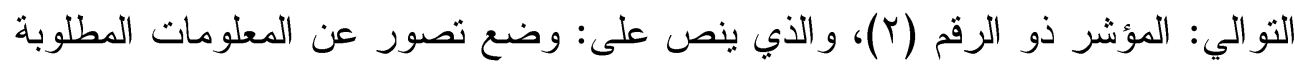

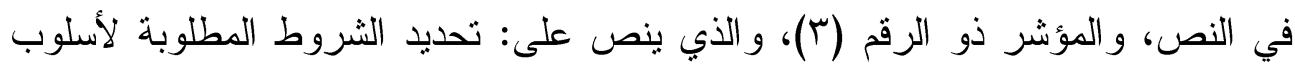

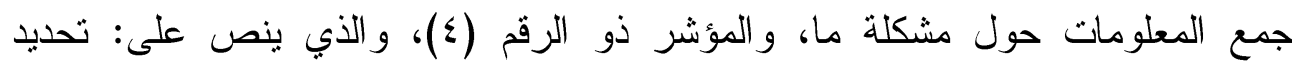

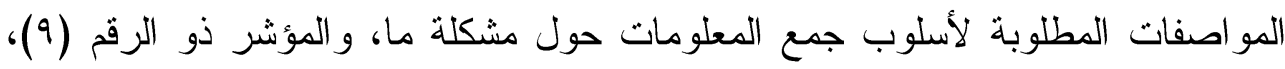

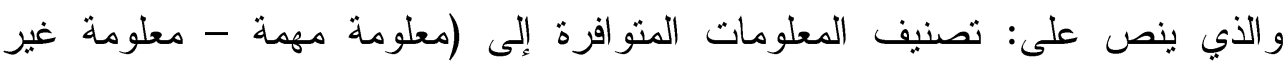
مهمة).

في حين نجد أن (. ب\%) من مؤشرات مهارة تحديد المشكلة لم تنضمنها أنشطة البرنامج التخصصي، بينما وجد (•ع\%) من هذه مؤشرات تضمنتها أنشطة البرنامج

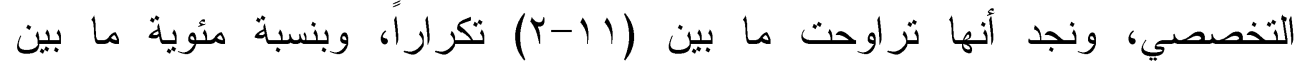
(1,11)

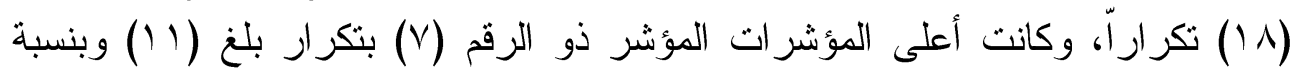

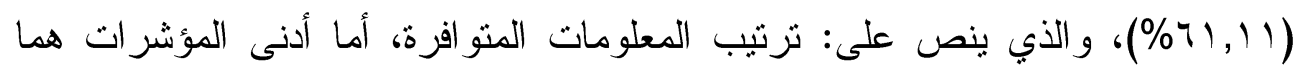

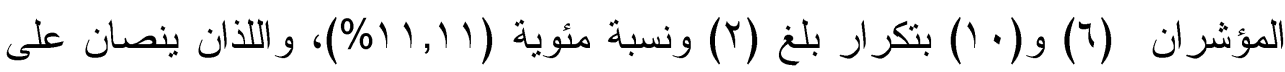

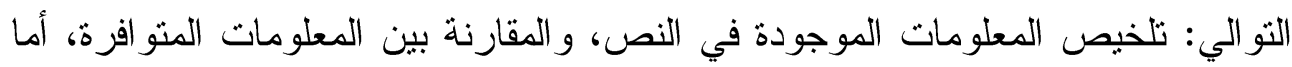

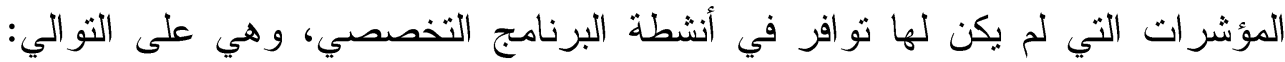

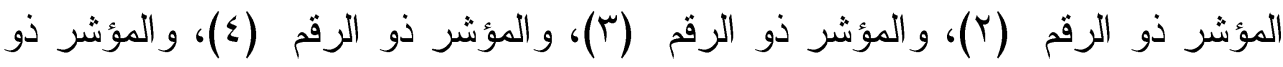

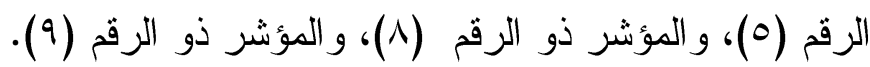


ب- مهارة تحديد البدائل:

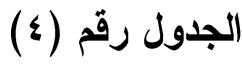

التكرارات والنسب المئوية لمهارة تحديد البدائل اللازم تضمينها في مقرر الثقافة

للمرحلة الثانوية "تظام المقررات"

\begin{tabular}{|c|c|c|c|c|c|c|c|c|c|}
\hline \multicolumn{2}{|c|}{ التخصصية الإسلامية } & \multirow{2}{*}{ ترهارة تحديب مؤشرات البدائل } & \multirow{2}{*}{ 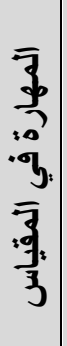 } & \multirow[t]{2}{*}{ 牙 } & \multicolumn{2}{|c|}{ الالإنلامية } & \multirow{2}{*}{ 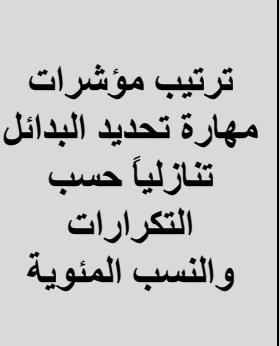 } & \multirow{2}{*}{ 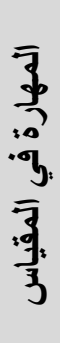 } & \multirow{2}{*}{ 㝵: } \\
\hline المئوية & 氞 & & & & المئوية & 氞 & & & \\
\hline$\% 0$. & 0 & إعلداد قائمة للبدائل & 1 & 1 & \% & 1 & إعلاد قائمة للبدائل & 1 & \\
\hline$\%$ \%. & $\varepsilon$ & في ألقائمةً. البائل المتو افرة & $r$ & $r$ & \% & 1 & في القيائمة. البدائل المتو افرة & $r$ & $r$ \\
\hline$\% 1$. & 1 & تحاديد قدرة البدائل & 0 & $r$ & $\% r$ & 1 & 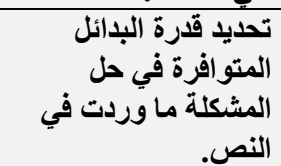 & 0 & $r$ \\
\hline$\% \cdot, \cdots$ &. & | وضع معايير تساعد على البلّئل & $\bar{r}$ & $\varepsilon$ & $\% \cdot, \cdots$ & $\cdot$ & 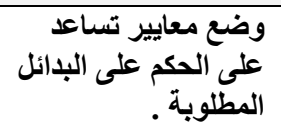 & $\bar{r}$ & $\varepsilon$ \\
\hline$\% \cdot, \cdots$ & • & 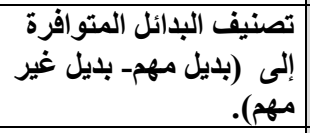 & $\varepsilon$ & 0 & $\% \cdot, \cdot \cdot$ & • & 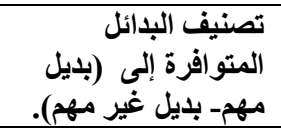 & $\varepsilon$ & 0 \\
\hline$\% \cdot, \cdots$ & . & | تحدويد نوع في البلائل مشكلة & 7 & 7 & $\% \cdot, \cdots$ & $\cdot$ & 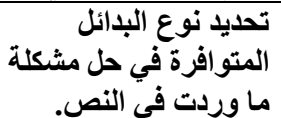 & 7 & 7 \\
\hline$\% \cdot, \cdots$ & . & 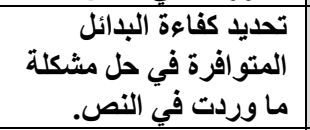 & $v$ & $v$ & $\% \cdot, \cdots$ & $\cdot$ & 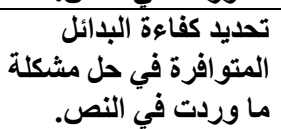 & V & $\bar{v}$ \\
\hline$\% \cdot, \cdots$ & • & 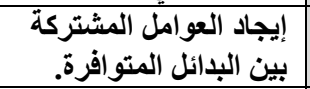 & $\wedge$ & $\lambda$ & $\% \cdot, \cdots$ & . & بين البدائل المتو المشرة . & $\lambda$ & $\wedge$ \\
\hline$\% \cdot, \cdots$ & . & بين البدائل المتو الفرتة. & 9 & 9 & $\% \cdot, \cdots$ & $\cdot$ & بين البدائل المتوافورة. & 9 & 9 \\
\hline$\%$ & 1 & ع الإجمالي & & & $\% 1 \ldots$ & $r$ & & & \\
\hline
\end{tabular}


يتضح من جدول التكرارات والنسبة المئوية لمؤشرات مهارة تحديد البدائل اللازم

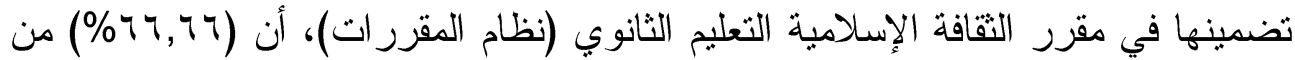
مؤشرات مهارة تحديد المشكلة لم تتضمنها أنشطة البرنامج المشترك، بينما وجد ( ) (Tr, من هذه المؤشرات تضمنتها أنشطة البرنامج المشترك، ونجد أنها تكررت مرة واحدة، وبنسبة مئوية (بr,rس\%)، وهي نسبة تعد منخفضة ، وقد بلغ مجموع التكر ارات (r) تكرارات، وكانت المؤشرات التي بلغ تكرارها (1) وبنسبة (rr,rr\%) و هي على التوالي: المؤشر ذو الرقم (1)، و الذي ينص على: إعداد قائمة للبدائل المطلوبة، و المؤشر ذو الرقم (ب) و الذي ينص على: تتظيم المعلومات المتو افرة، و المؤشر ذو الرقم (0)، و الذي بنص على: تحديد قدرة البدائل المتو افرة في حل المشكلة ما وردت في النص، أما المؤشرات التي لم يكن لها تو افر في أنشطة البرنامج المشترك، وهي: المؤشر ذو الرقم (Y)، و الذي ينص على: وضع معايير نساعد على الحكم على البدائل المطلوبة، و المؤشر ذو الرقم (ع)، و الذي ينص على: تصنيف البدائل المتو افرة إلى لى (بديل مهم- بديل غير مهم)، و المؤشر ذو الرقم (ا)، و الذي ينص على: تحديد نوع البدائل المتو افرة في حل مشكلة ما وردت في النص، و المؤشر ذو الرقم (V)، و الذي ينص على: تحديد كفاءة البدائل المتو افرة في حل مشكلة ما وردت في النص، و المؤشر ذو الرقم (^)، و الذي ينص على: إيجاد العو امل المشتركة بين البدائل المتو افرة، و المؤشر ذو الرقم (9)، و الذي ينص على: إيجاد العو امل المختلفة بين البدائل المتو افرة. في حين نجد أن (77,77\%) من مؤشرات مهارة تحديد البدائل لم تتضمنها أنشطة البرنامج التخصصي، بينما وجد (rr,rr\%) من هذه المؤشر ات تضمنتها أنشطة البرنامج

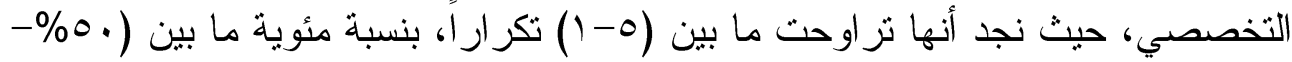
• (\%)، و هي نسبة تعد منخفضة، وقد بلغ مجموع التكرارات (• (1) تكرارات، وكانت

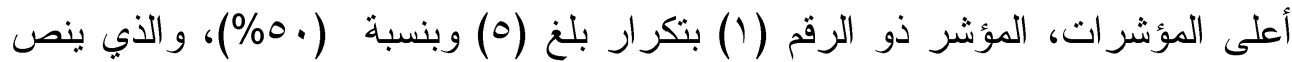
على: إعداد قائمة للبدائل المطلوبة، أما أدنى المؤشرات المؤشر ذو الرقم (0) بتكرار بلغ (1) وبنسبة (• (\%)، و الذي ينص على: تحديد قدرة البدائل المتو افرة في حل المشكلة ما وردت في النص، أما المؤشرات التي لم يكن لها تو افر في أنشطة البرنامج التخصصي 
و هي: المؤشر ذو الرقم (Y)، و الذي ينص على: وضع معايير تساعد على الحكم على

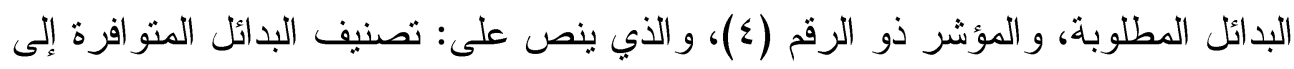

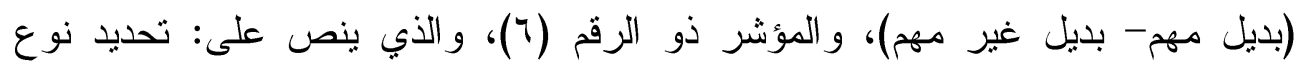

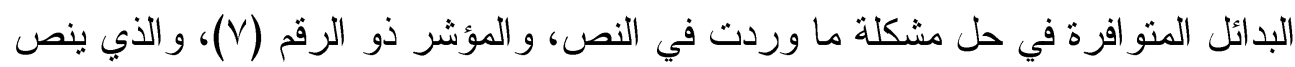
على: تحديد كفاءة البدائل المنو افرة في حل مشكلة ما وردت في النص، و المؤشر ذو الرقم

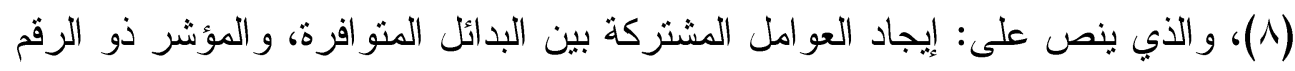
(9)، و الذي ينص على: إيجاد العو امل المختلفة بين البدائل المتو افرة. 
ع - مهارة اختيار أفضل البدائل:

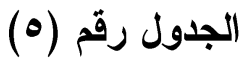

التكرارات والنسب المئوية لمهارة اختيار أفضل البدائل اللازم تضمينها في مقرر الثقافة

للمرحلة الثانوية "نظام المقررات"

\begin{tabular}{|c|c|c|c|c|c|c|c|c|c|}
\hline \multicolumn{2}{|c|}{ 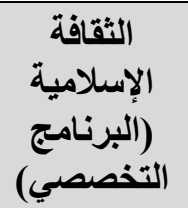 } & \multirow{2}{*}{ 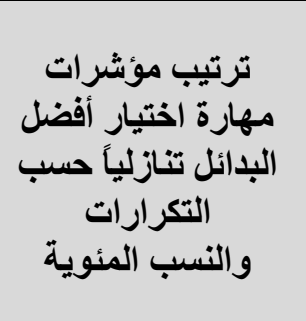 } & \multirow{2}{*}{ 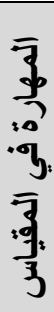 } & \multirow[t]{2}{*}{ 䄈: } & \multicolumn{2}{|c|}{ 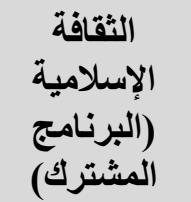 } & \multirow{2}{*}{ 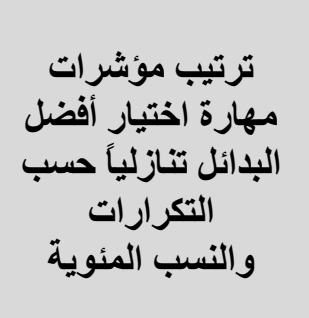 } & \multirow{2}{*}{ 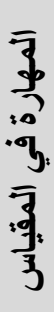 } & \multirow[t]{2}{*}{ 浔 } \\
\hline المئوية & 昰 & & & & المئوية & 昰 & & & \\
\hline$\% 0^{\circ}$. & 1 & اختيار البديل الأكثر فعالية. & 1 & 1 & $\% 1 \ldots$ & 1 & المتغليا مدلى البديل للإمكانيات & $r$ & 1 \\
\hline$\% 0$ & 1 & المتواضلة بين البدائل & 9 & T & $\% \cdot \cdots$ & . & في اخيادية والبعد عن الأتية & 1 & $r$ \\
\hline$\%$ & $\cdot$ & في اختيار البدائلة عن الأتية & 1 & $r$ & $\%$ & . & 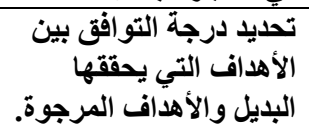 & $r$ & $r$ \\
\hline$\%, \cdots$ & . & الأهديد داف التي يحقة التوافق بين & r & $\varepsilon$ & $\%$ & . & الحتيد مدى مناسبة البتايل للموارد & $\varepsilon$ & $\varepsilon$ \\
\hline$\%$ & . & العتغلال مدل البديل للإمكانيات & $r$ & 0 & $\%$ & . & تالظرويد مدى مناسبة المحيطة للأخذ & 0 & 0 \\
\hline$\%$ & $\cdot$ & 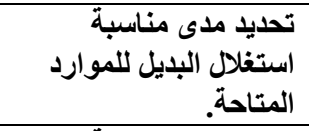 & $\varepsilon$ & 7 & $\% \cdot \ldots$ & . & لتلاخذّ بالبديل مدايل المقترحة الوقت & 7 & 7 \\
\hline$\%, \cdots$ & . & تالظديد مدى المحيطة للأخذ & 0 & V & $\% \cdot \cdots$ & . & تحليل مليها كل درة التي ينطوي & 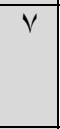 & $V$ \\
\hline$\%$ & $\cdot$ & تلأذذّ بالبديل مناسبة المقترح. & 7 & $\wedge$ & $\% \cdot \ldots$ & . & 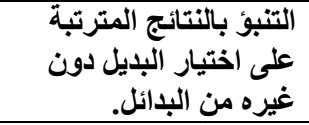 & $\wedge$ & $\wedge$ \\
\hline$\%$ & $\cdot$ & 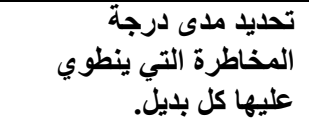 & $\mathrm{V}$ & 9 & $\% \cdot \ldots$ & - & المتوافرة. بين البدائل & 9 & 9 \\
\hline$\%$ & $\cdot$ & 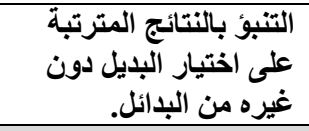 & $\Lambda$ & ? & $\%$ & . & فعالية. & 1 & 1 \\
\hline$\%$ & Y & ع الإجمالي & & & $\%$ & 1 & ج جمالي & & \\
\hline
\end{tabular}


يتضح من جدول التكرار ات و النسبة المئوية لمؤشرات مهارة اختيار أفضل البدائل اللازم تضمينها في مقرر الثقافة الإسلامية التعليم الثانوي (نظام المقررات)، أن (.9\%) من مؤشرات مهارة اختيار أفضل البدائل لم تتضمنها أنشطة البرنامج المشترك، بينما وجد ((\%) من هذه المؤشرات تضمنتها أنشطة البرنامج المشترك، وتعد نسبة منخفضة جداً، ووجد أن المؤشر الذي بلغ تكرارها (1) تكراراً، وهو: المؤشر ذات الرقم (ب)، والذي ينص على: تحديد مدى مناسبة استغلال البديل للإمكانيات المتاحة. أما المؤشرات التي لم يكن لها توافر في أنشطة البرنامج المشترك، وهي على التوالي: المؤشر ذو الرقم (1)، والذي ينص على: الحيادية والبعد عن الذاتية في اختيار البدائل، و المؤشر ذو الرقم (Y)، و الذي ينص على: تحديد درجة التو افق بين الأهداف التي يحققها البديل والأهداف المرجوة، و المؤشر ذو الرقم (ع)، و الذي ينص على: تحديد مدى مناسبة استغلال البديل للمو ارد المتاحة، و المؤشر ذو الرقم (0)، و الذي ينص على: تحديد مدى مناسبة الظروف المحيطة للأخذ بالبديل المقترح، والمؤشر ذو الرقم (؟)، والذي ينص على: تحديد مدى مناسبة الوقت للأخذ بالبديل المقترح، و المؤشر ذو الرقم (V)، و الذي ينص على: تحديد مدى درجة المخاطرة التي ينطوي عليها كل بديل، و المؤشر ذو الرقم (^)، و الذي ينص على: التنبؤ بالنتائج المثرنبة على اختبار البديل دون غيره من البدائل، و المؤشر ذو الرقم (9)، و الذي ينص على: المفاضلة بين البدائل المتو افرة، و المؤشر ذو الرقم (• (1)، و الذي ينص على: اختيار البديل الأكثر فعالية. في حين نجد أن (•^\%) من مؤشرات مهارة اختيار أفضل البدائل لم تتضمنها أنشطة البرنامج التخصصي، بينما وجد (·r\%)من هذه المؤشرات تضمنتها أنشطة البرنامج التخصصي، ونجد أنها نزاوحت ما بين (1-1) تكراراً، بنسبة مئوية ما بين

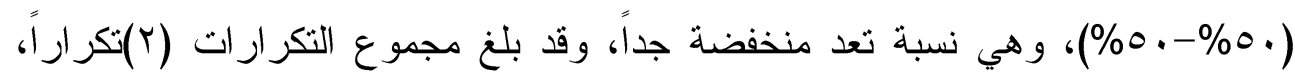


وكانت المؤشر ات المتو افرة في أنشطة البرنامج التخصصي وهي: المؤشر ذو الرقم (• () بتكرار بلغ (1) وبنسبة (.0\%)، و الذي ينص على: اختيار البديل الأكثر فعالية، و المؤشر ذو الرقم (9) بتكرار بلغ (1) وبنسبة (•0\%)، و الذي ينص على: المفاضلة بين البدائل المثو افرة. أما المؤشرات التي لم يكن لها تو افراً في أنشطة البرنامج التخصصي، وهي على لـ التوالي: وهي: المؤشر ذو الرقم (1)، و الذي ينص على: الحيادية و البعد عن الذاتية في اختيار البدائل، و المؤشر ذو الرقم (Y)، و الذي ينص على: تحديد درجة التوافق بين الأهداف التي يحققها البديل والأهداف المرجوة، و المؤشر ذو الرقم (r)، و الذي ينص على: تحديد مدى مناسبة استخلال البديل للإمكانيات المتاحة، والمؤشر ذو الرقم (ع)، و الذي ينص على: تحديد مدى مناسبة استغلال البديل للموارد المناحة، والمؤشر ذو الرقم (0)، و الذي ينص على: تحديد مدى مناسبة الظروف المحيطة للأخذ بالبديل المقترح، و المؤشر ذو الرقم (T)، و الذي ينص على: تحديد مدى مناسبة الوقت للأخذ بالبديل المقترح، و المؤشر ذو الرقم (V)، و الذي ينص على: تحديد مدى درجة المخاطرة التي ينطوي عليها كل بديل، و المؤشر ذو الرقم (^)، و الذي ينص على: التنبؤ بالنتائج المترثبة على اختبار البديل دون غيره من البدائل. 


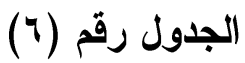

التكرارات والنسب المئوية لمهارة إصدار القرار اللازم تضمينها في مقرر الثقافة

للمرحلة الثانوية "نظام المقررات"

\begin{tabular}{|c|c|c|c|c|c|c|c|c|c|}
\hline \multicolumn{2}{|c|}{ 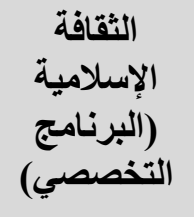 } & \multirow{2}{*}{ 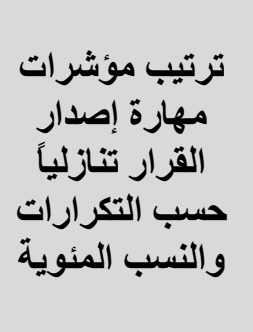 } & \multirow{2}{*}{$\begin{array}{l}\overline{3} \\
3 \\
: 0 \\
3 \\
\overline{3} \\
3 \\
3\end{array}$} & \multirow[t]{2}{*}{ 涾: } & \multicolumn{2}{|c|}{ الإسلامية الثقافة } & \multirow{2}{*}{ 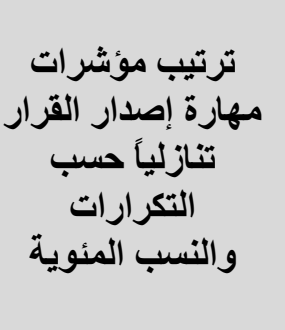 } & \multirow{2}{*}{ 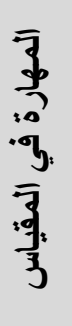 } & \multirow[t]{2}{*}{ 牙: } \\
\hline المئوية & $\frac{\text { 氞 }}{7}$ & & & & المئوية & 氞 & & & \\
\hline $0 \% 7$. & r & 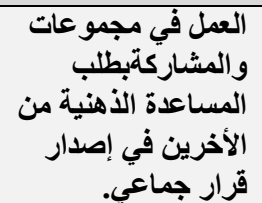 & 1 & 1 & $\begin{array}{r}77, V \\
\%\end{array}$ & $r$ & 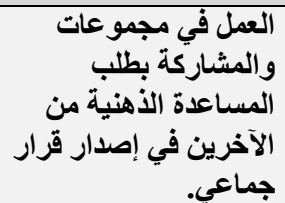 & 1 & 1 \\
\hline$\%$ \&. & $r$ & 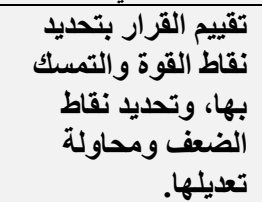 & $\Lambda$ & $r$ & r & 1 & 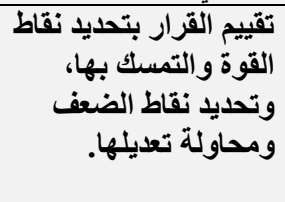 & $\Lambda$ & r \\
\hline$\stackrel{\bullet}{*}$ & . & قرار. تحدالهدفنإصدارال & $r$ & $r$ & $\cdot \ddot{*}$ & . & تحداري الهدف من إصدار & $r$ & $r$ \\
\hline $\begin{array}{r}\cdot, \cdot \\
\%\end{array}$ & • & قرارقبلالتنفيذّ. & r & $\varepsilon$ & $\cdot \ddot{*}$ & . & الترار قبل التنفيذ. & $r$ & $\varepsilon$ \\
\hline 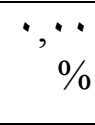 & - & الاستريث وعال عدم إصدار & $\varepsilon$ & 0 & $\cdot \ddot{*}$ & . & عند إصدار القرار. الاستعجال & $\varepsilon$ & 0 \\
\hline$\stackrel{\bullet}{\%}$ & • & عدان. عالتثربقراراتالأخر & 0 & 7 & $\cdot \ddot{*}$ & . & 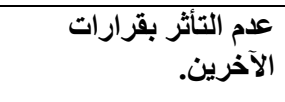 & 0 & 7 \\
\hline 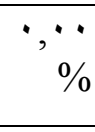 & • & تقديم الحجب & 7 & $\bar{v}$ & $\cdot \ddot{*}$ & . & تقديم الصدار القرار. والمبررات & 7 & $\bar{V}$ \\
\hline$\stackrel{\bullet}{\%}$ & • & عند إصدار القرار. المناسب & $\mathrm{V}$ & $\Lambda$ & $\cdot \ddot{*}$ & • & عند إصدار الوقت المناسب & $\mathrm{V}$ & $\Lambda$ \\
\hline$\stackrel{\bullet}{*}$ & • & ثن تثيذ القرار الصادر & 9 & 9 & $\stackrel{\cdots}{*}$ & • & تتفيذ القرار الصادر ثم & 9 & 9 \\
\hline$\% 1 \ldots$ & - & 'جمالي & 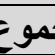 & & $\% 1 \ldots$ & $r$ & & & \\
\hline
\end{tabular}


يتضح من جدول التكرار ات و النسبة المئوية لمؤشرات إصدار القرار اللازم تضمينها في مقرر الثقافة الإسلامية التعليم الثانوي (نظام المقررات)، أن (\% \% من مؤشرات

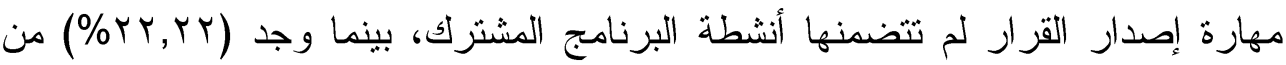
هذه المؤشرات تضمنتها أنشطة البرنامج المشترك، ونجد أنها تزاوحت ما بين (r-1)

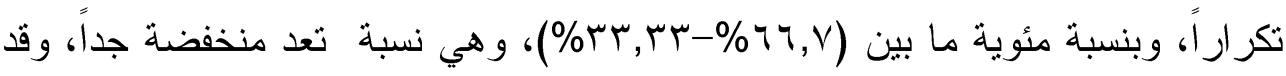
بلغ مجموع التكرارات (r) تكرارات، وكانت أعلى المؤشرات المؤشر ذو الرقم (1) بتكر ار بلغ (Y) وبنسبة (Y,Yr\%)، و الذي ينص على: العمل في مجموعات و المشاركة بطلب المساعدة الذهنية من الآخرين في إصدار قرار جماعي، أما أدنى المؤشرات

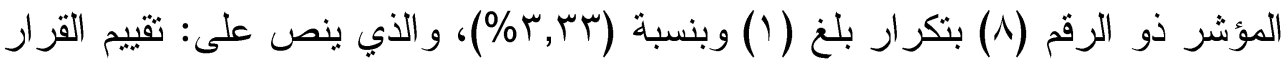
بتحديد نقاط القوة و التمسك بها، وتحديد نقاط الضعف ومحاولة تعديلها، أما المؤشرات التي لم يكن لها تو افراً في أنشطة البرنامج المشترك، وهي على التو الي: المؤشر ذو الرقم (Y)، و الذي ينص على: تحديد الهدف من إصدار القرار، و المؤشر ذو الرقم (r)، و الذي ينص على: التقكير بمنطلبات اتخاذ القرار قبل التنفيذ، والمؤشر ذو الرقم (ع)، و الذي ينص على: التزيث وعدم الاستعجال عند إصدار القرار، و المؤشر ذو الرقم (0)، والذي ينص على: عدم التأثز بقرارات الآخرين، والمؤشر ذو الرقم (آ)، والذي ينص على: تقديم الحجج و المبررات عند إصدار القرار، و المؤشر ذو الرقم (V)، و الذي ينص على: اختيار الوقت المناسب عند إصدار القرار، والمؤشر ذو الرقم (9)، و الذي ينص على: تتفيذ القرار الصادر ثم متابعته. في حين نجد أن (\%>^) من مؤشرات مهارة إصدار القرار لم تتضمنها أنشطة البرنامج التخصصي، بينما وجد (Yr\%) من هذه المؤشرات تضمنتها أنشطة البرنامج

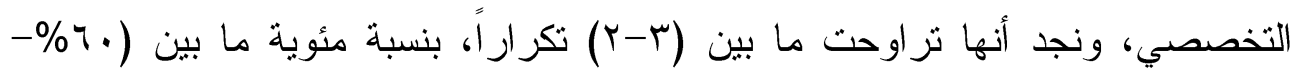


• ع\%) و هي نسبة منخفضة جداً، وقد بلغ مجموع التكر ار ات (0) تكرار ات، وكانت أعلى المؤشرات المؤشر ذو الرقم (1) بتكرار بلغ (ب) وبنسبة (.7\%)، و الذي ينص على: العمل في مجموعات و المشاركة بطلب المساعدة الذهنية من الأخرين في إصدار قرار جماعي، أما أدنى المؤشرات المؤشر ذو الرقم (^) بتكرار بلغ (r) وبنسبة (•؛\%)، و الذي ينص على: تقييم القرار بتحديد نقاط القوة والتمسك بها، وتحديد نقاط الضعف

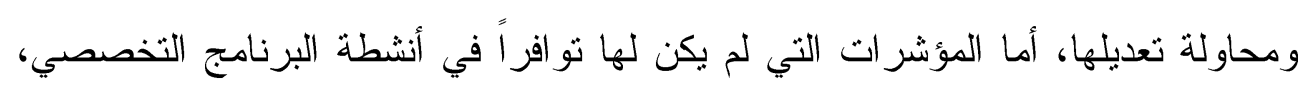
و هي على التو الي: المؤشر ذو الرقم (Y)، و الذي ينص على: تحديد الهدف من إصدار القرار، و المؤشر ذو الرقم (ب)، و الذي ينص على: التقكير بمنطلبات اتخاذ القرار قبل التنفيذ، و المؤشر ذو الرقم (ع)، و الذي ينص على: التريث وعدم الاستعجال عند إصدار القرار، و المؤشر ذو الرقم (0)، والذي ينص على: عدم التأثر بقرارات الآخرين، و المؤشر ذو الرقم (T)، و الذي ينص على: تقديم الحجج و المبررات عند إصدار القرار، و المؤشر ذو الرقم (V)، و الذي ينص على: اختيار الوقت المناسب عند إصدار القرار، و المؤشر ذو الرقم (9)، والذي ينص على: تنفيذ القرار الصادر ثم متابعته. ولمعرفة مدى تضمين مهار ات اتخاذ القزار (تحديد المشكلة، جمع المعلومات، تحديد البدائل، اختيار أفضل البدائل، إصدار القرار) في مقرر الثقافة الإسلامية (البرنامج المشترك، و البرنامج التخصصي) للمرحلة الثانوية "نظام المقررات"، تم استخر اج التكرارات لكل مهارة ورصدت في الجدول رقم (9)، ثم حسبت النسبة المئوية ورثبت تتازلياً حسب التكرارات و النسب المئوية، وقد جاءت النتائج موضحة ذلك على النحو الآتي: - n 
(v) الجدول رق اق)

\begin{tabular}{|c|c|c|c|c|c|c|c|c|c|}
\hline \multicolumn{2}{|c|}{ التقافة الإسلامية } & \multirow{2}{*}{ ترتيب مهارات التخاز القرار } & \multirow{2}{*}{$\begin{array}{l}\overline{3} \\
: 0 \\
: 03 \\
\overline{3}:\end{array}$} & \multirow{2}{*}{ 牙: } & \multicolumn{2}{|c|}{ (البرنامج المشترة الإشلامية) } & \multirow{2}{*}{ 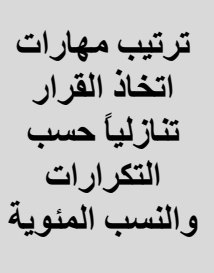 } & \multirow{2}{*}{ 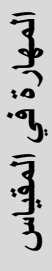 } & \multirow{2}{*}{ 牙 } \\
\hline المئوية & التكرار & & & & المئوية & التكرار & & & \\
\hline $\begin{array}{c}00,1 \\
\%\end{array}$ & $\varepsilon \Gamma$ & تحديد المشكلة & 1 & 1 & $\begin{array}{r}77, Y \wedge \\
\%\end{array}$ & OV & تحديد المشكلة & 1 & 1 \\
\hline $\begin{array}{l}r r, \\
\% \wedge\end{array}$ & 11 & جمع المعلومات & $r$ & $r$ & $\begin{array}{r}r 0,0 \wedge \\
\%\end{array}$ & YY & جمع المعلومات & $r$ & $r$ \\
\hline $\begin{array}{l}1 Y, \wedge \\
\%\end{array}$ & 1. & تحديد البدائل & $r$ & $r$ & $\% r, \leqslant q$ & $r$ & تحديد البدائل & $r$ & $r$ \\
\hline $\begin{array}{r}7, \leqslant 1 \\
\%\end{array}$ & 0 & إصدار القرار & 0 & $\varepsilon$ & $\% r, \leqslant q$ & $\mu$ & إصدار القرار & 0 & $\varepsilon$ \\
\hline $\begin{array}{r}r, 07 \\
\%\end{array}$ & r & البدائل أفضل & $\varepsilon$ & 0 & $\% 1,17$ & 1 & البدائل أفضل & $\varepsilon$ & 0 \\
\hline $\begin{array}{r}1 \ldots \\
\%\end{array}$ & $\vee \wedge$ & ل جمالي & 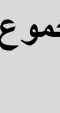 & & $\% 1 \ldots$ & $\wedge$ & لجمالي & & \\
\hline
\end{tabular}

يوضح التكرارات والنسب المئوية لمهارة اتخاذ القرار اللازم تضمينها في مقرر الثقافة للمرحلة الثانوية "نظام المقررات"

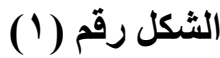
يوضح توزيع مهارة اتخاذ القرار حسب توافرها في مقرر الثقافة الإسلامية

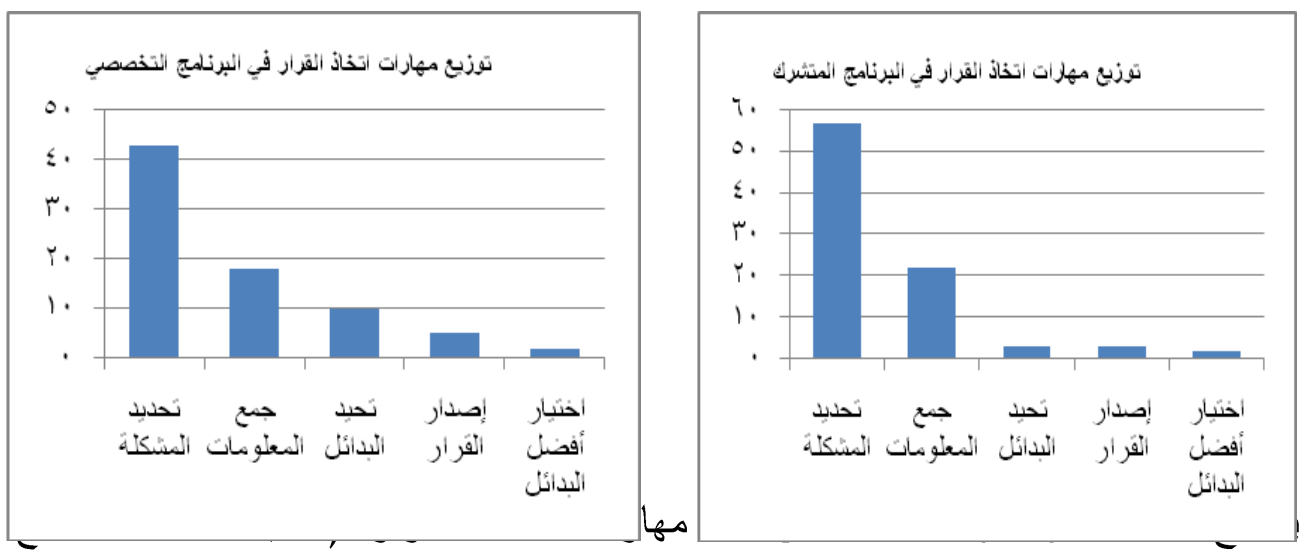

المعلومات، تحديد البدائل، اختيار أفضل البدائل، إصدار القرار) متضمنة في أنشطة مقرر 
النقافة الإسلامية (البرنامج المشترك، البرنامج التخصصي) بنسبٍ متفاونة، وبالنظر إلى الى النى

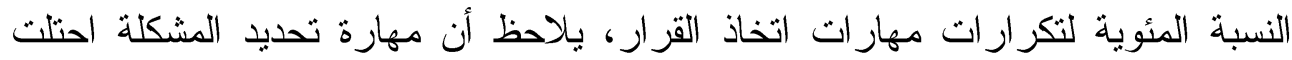
المرتبة الأولى، حيث كانت النسبة الأعلى لها من عينة البحث، لمقرر الثقافة الإسلامية

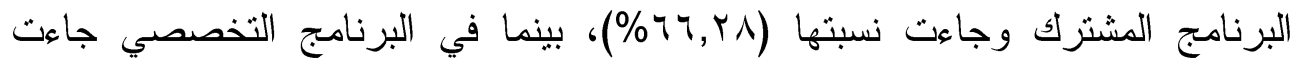
نسبتها (\%) (\%) أما مهارة جمع المعلومات فقد احتلت المرنبة الثانية، حيث كانت النسبة الأعلى لها

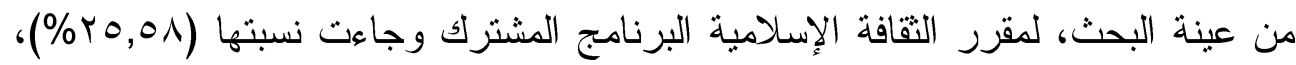
بينما في البرنامج التخصصي جاءت نسبتها (1 •, بr\%). أما مهارة تحديد البدائل فقد احتلث المرتبة الثالثة، حيث كانت النسبة الأعلى لها من

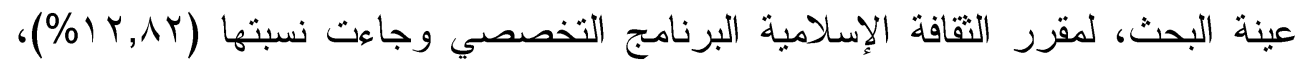
أما مهارة إصدار القرار فقد احتلت المرنبة الر ابعة، حيث كانت النسبة الأعلى لها من النه

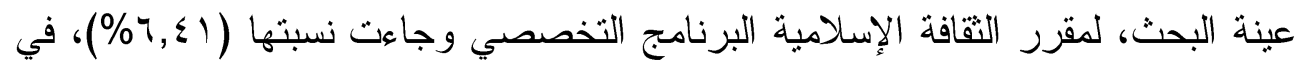
حين نجد أن كل من مهارة تحديد البدائل، ومهارة إصدار القرار جاءت نسبتهما

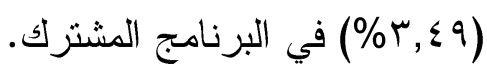

أما مهارة اختبار أفضل البدائل فقد احتلت المرثبة الخامسة، حيث كانت النسبة الأعلى لها من عينة البحث، لمقرر الثقافة الإسلامية البرنامج التخصصي وجاءت نسبتها

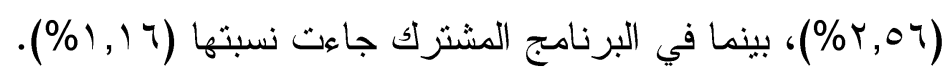
ومن خلال العرض السابق تشير النتائج إلى أن مهار ات اتخاذ القرار (تحديد المشكلة، جمع المعلومات، تحديد البدائل، اختيار أفضل البدائل، إصدار القرار) متو افرة إنى

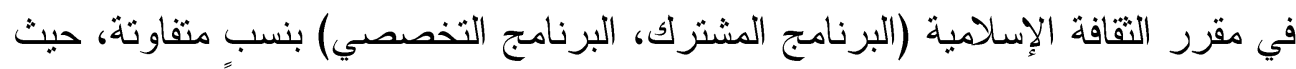

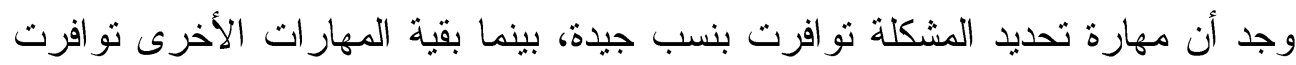
بنسب ضئيلة جداّ، وتضمينها بنسب ضئيلة يؤكد الخلل المنهي في الأنشطة التعليمية الني لئي

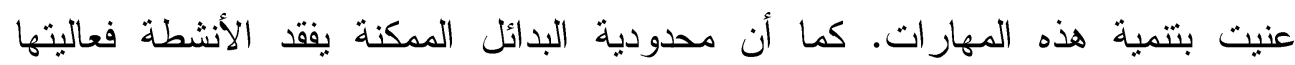
وجدو اها في تتمية مهارة اتخاذ القرار. 
وربما يعود تفسير تضمين مهارة تحديد المشكلة بنسبة أعلى من المهار ات الأخرى، إلى تزكيز منهج التقافة الإسلامية على العديد من الموضوعات التي تتاولت العديد من المشكلات الحياتية، و القضايا المعاصرة، والتي تحتاج إلى حل واتخاذ قرار مناسب

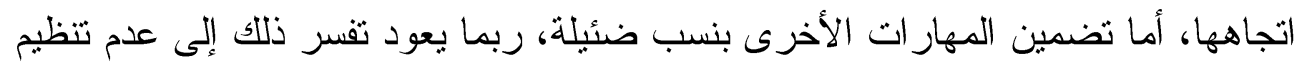

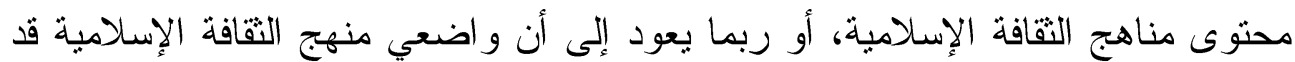

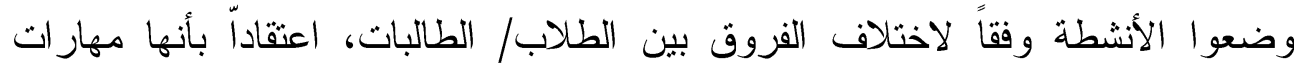
تفكير عليا، قد لا تتناسب مع جميع الفئات، و إنما تضمينها جاءت لتلبية احتباجات فئة معينة ، كما تعزو الدراسة الحالية أقلية تكرارات تلك المهارات إلى قلة الأنشطة الواردة في المقرر، ربما يفسر ذلك غيابها لدى مؤلفي منهج الثقافة الإسلامية. كما يتضح أن نسب تمثيل هذه المهار ات غير منوازن، فعلى الرغم من أنه لا يوجد نسب توزيع محددة لتلك المهارات، إلا أن التباين كبير جداً وواضح، فقي البرنامج

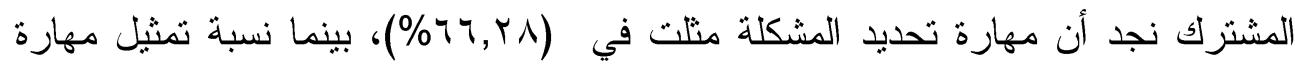
اختيار أفضل البدائل لا تتعدى (7 (, 1\%)، أما بالنسبة للبرنامج التخصصي نجد أن مهارة

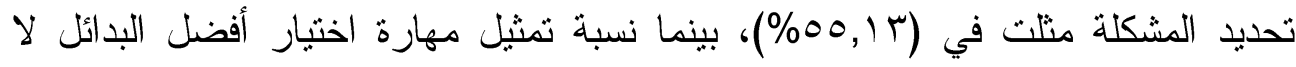
تتعدى (\% (\% r.07). ومن الملاحظ على هذه النتائج أن مهارات اتخاذ القرار لم تلق الاهتمام الكافي من مخططي وو اضعي المناهج، كما لم تلق الاهتمام الكافي من قبل الباحثين، فقد تفردت الدارسة الحالية بهذه النتيجة حيث لم تتتاول الدراسات السابقة هذا المتغير بالتحليل. وبذلك تكون الباحثة قد أجابت على السؤال الثاني من أسئلة الدراسة المتعلقة بتتمبة بانة مهارات اتخاذ القرار اللازم تتمينها في مقرر الثقافة الإسلامية للمرحلة الثانوية (نظام

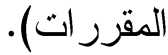




\section{إجابة السؤال الثالث وتفسيره ومناقشته:}

ينص السؤال الأول على: ما التصور المقتزح لنظوير مقرر الثقافة الإسلامية

اللمرحلة الثانوية في ضوء تنمية اتخاذ القرار ؟

للإجابة عن هذا السؤال قامت الباحثة بتقديم تصور مقترح لتطوير أنشطة مقرر

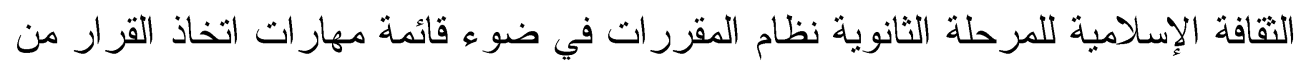

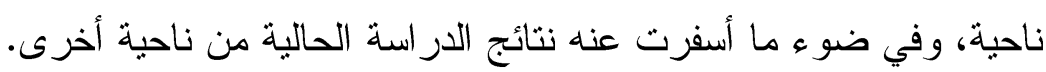

ولبناء هذا التصور كان لابد من السير على خطوات صحيحة، وحتى تكون صحيحة

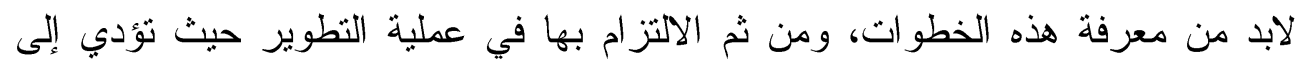

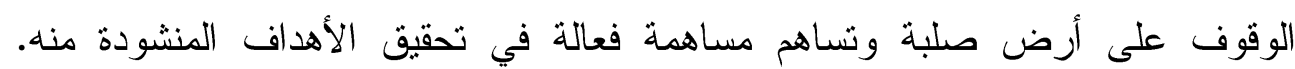

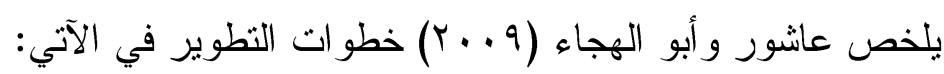

1- الإحساس بضرورة تطوير المناهج الدراسية.

r- دراسة مسحية تحليلية لو اقع المناهج الدراسية بهدف التعرف إلى مستواها، و الفلسفة

التي تستند إليها.

r- تحديد الحاجات الاجتماعبة و السيكولوجية و الأسس المناسبة التي ستركز عليها المناهج

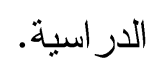

ع- تحديد عناصر المنهج الرئيسة المنثلة في الأهداف و أساليب النتريس و النقويم.

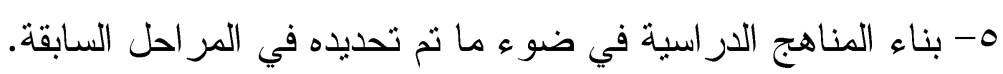

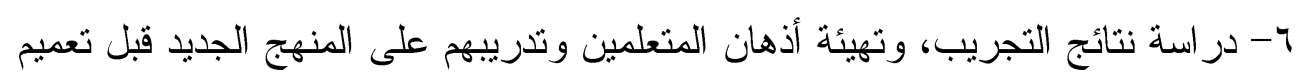
المنهج. V- تنفيذ المناهج الدراسية الجديدة، وقيام المعلمين بكتابة نقارير عن الصعوبات التي تو اجهه المنهج

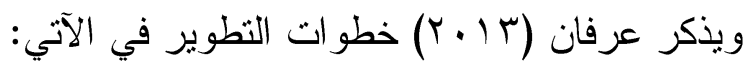

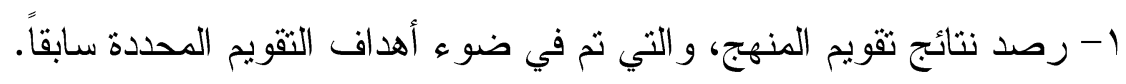

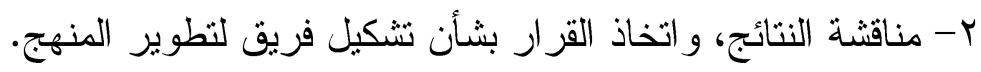

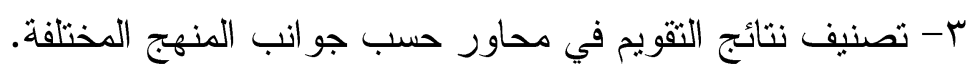


ع - تحديد أهداف التطوير. 0- وضع مخطط زمني للنطوير - ون צ- تحديد آليات التطوير. - V ^- وضع القو اعد و الأصول و التعليمات، و التي ستر اعي في عملية نطوير. 9- توزيع مهام النطوير على أعضاء الفريق. • 1- تنفيذ التطوير على مر احل متتابعة. 11 ا - ثقويم كل مرحلة من مرحل التطوير.

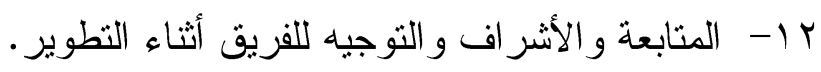
rا - عمل ثقرير شامل عن النطوير من قبل أعضاء الفريق النطوير. ع ا- تجريب المنهج بعد النطوير - أن 10 - 10 - رصد نتائجه. و 17 - اتخاذ القرار بتعميم المنهج.

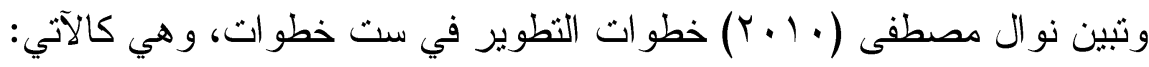
1- إجر اء عملية القياس للحصول على بيانات لازمة. ץ- تحديد قيمة قياسية تتسب إليها، وقيمة الخاصية التي تقيسها" التقييم".

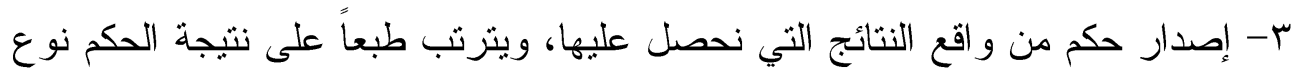
الإجر اء.

ع- تزويد صانعي القرار بالمعلومات اللازمة لاتخاذ القرارات لتطوير أو تعديل في العملية التعليمية. ه- تزويد أولياء الأمور بالمعلومات عن تقدم ابنائهم. ج- تزويد وتوجيه المتعلمين للتعرف على مستوى تحصيلهم، ومعرفه نقاط قوتهم وضعفهم.

وفي ضوء ما سبق تقترح الباحثة في الدراسة الحالية تصور لنطوير أنشطة مقرر

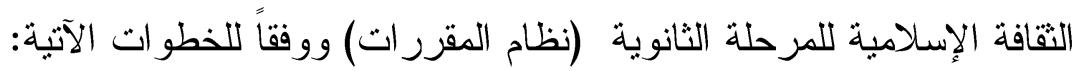


1- مبرر ات التصور المقترح.

ץ- إجر اءات التصور المقترح.

r- مكونات التصور المقترح.

ع- التهيئة لتجريب التصور المقترح.

ه- تجريب التصور المقترح.

צ- الاستعداد لتعميم التصور المقتر ح.

V- Vعميم التصور المقترح.

^- متابعة التصور المقترح.

اقتصر جهد الباحثة على الخطوات الثلاث الأولى، أما الخطوات المثبقية، فتقتح

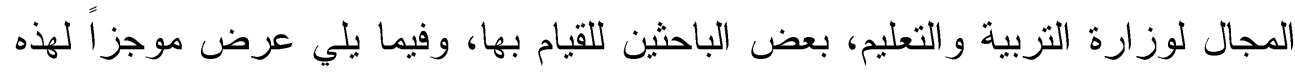
الخطو ات:

أولاً: مبررات التصور المقترح:

تحددت مبررات التصور المقترح في الآتي:

1- مو اكبة لتغيرات المعاصرة، و المستجدات الحياتية التي طر أت في مختلف مجالات، و استجابة لمنطلبات التتمية المختلفة، و التي من بينها تتمية العنصر البشري لتسليحه بالفكر الو اعي، وتأهيله لحل مشكلاته ولمو اجهة التحديات. r- عدم كفاءة منهج الثقافة الإسلامية في إتاحة الفرصة أمام الدارسين لتنمية أفكار هم، وتتمية بعض مهار ات اتخاذ القزار لايهم لممارستها في مو اقف عديدة، مما بطلب الأمر تقويم المنهج بما بحقق حاجاتهم، حتى بستطيعو ا أن يقيمو ا حاضر هم ومستقبلهم، ويستقيدوا بما لديهم من مهار ات في اتخاذ قرار ات مناسبة لتحسين حياتهم المستقبلية. r- الرغبة في نلافي نواحي القصور التي أظهرتها نتائج الدر اسة الحالية في ثقويم مناهج الثقافة الإسلامية القائمة حالياً، والمنمثلة في افتقار ها الى أنشطة تنمي ههار ات اتخاذ التهاذ القرار، للوصول بها إلى درجة عالية من الكفاءة والفاعلية الداخلية و الخارجية. ثانياً: إجراءات التصور المقترح: تحددت إجر اءات التصور المقترح بقيام الباحثة بالآتي: 
1- بناء قائمة بمهار ات اتخاذ القرار.

r- تحليل أنشطة مقرر الثقافة الإسلامية للمرحلة الثانوية (نظام المقررات)، في ضوء القائمة السابقة لمعرفة مدى تضمين الأنشطة لمهار ات اتخاذ القز ار. ب- تحديد المهار ات التي لم تتضمنها أنشطة مقرر الثقافة الإسلامية للمرحلة الثانوية (نظام (المقرر ات). ع- بناء التصور المقترح وفقاً، لخطوات نموذج تايلور ، وهي كالآتي: الخطوة الأولى: وضع أهداف عامة قابلة للتعديل. الخطوة الثانية: تنقيح الأهداف وتتقيتها من خلال مصفاتين، هما فلسفة التزبية وعلم نفس المتعلم. الخطوة الثالثة: اختيار خبر ات التعلم في ضوء الأهداف العامة. الخطوة الر ابعة: تتظيم هذه الخبرة. الخطوة الخامسة :توجيه هذه الخبر ات. الخطوة السادسة: تقويم خبر ات التعلم. ه- تضمين مهار ات اتخاذ القرار في أنشطة مقرر الثقافة الإسلامية للمرحلة الثانوية (نظام المقرر ات)، في ضوء القائمة السابقة. ثالثاً: مكونات التصور المقترح: أولاً: تحديد الأهداف: مكونات الصور: تحددت أهداف التصور المقترح في الآتي: 1- الاحساس بالمشكلة في الحالة التي تحتاج إلى اتخاذ قرار ما. r- ربط الإحساس بالمشكلة بالو اقع. ب- تحديد الهدف من اتخاذ القرار حول مشكلة ما وردت في النص. ع- وضع معايير لدر اسة مشكلة ما وردت في النص. ه- وصف المشكلة وصفاً دقيقاً.

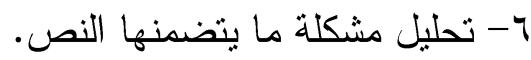
- تحديد أسباب حدوث مشكلة ما وردت في النص. 
^- تحديد العو امل الإيجابية المؤثرة في حل المشكلة. 9- تحديد العو امل السلبية المؤثرة في حل المشكلة. • (- توضيح العلاقات بين جوانب المشكلة (أسبابها- نتائجها). 11 - تحديد مصادر الحصول على المعلومات حول مشكلة. r ا - وضع تصور عن المعلومات المطلوبة في النص لحل مشكلة. rا - تحديد الشروط المطلوبة لأسلوب جمع المعلومات حول مشكلة ما. ع ا - تحديد المو اصفات المطلوبة لأسلوب جمع المعلومات حول مشكلة ما. 10 17 - تلخيص معلومات حول مشكلة موجودة في النص. IV 1 ا - تتظيم المعلومات المتو افرة حول المشكلة. 9 1ا- تصنيف المعلومات المتو افرة حول المشكلة إلى (معلومة مهمة - معلومة غير مهمة). • ب- المقارنة بين المعلومات المتو افرة حول المشكلة. ا ا ب - إعداد قائمة للبدائل المطلوبة. r r- وضع معايير تساعد على الحكم على البدائل المطلوبة. بr- ترثيب البدائل المتو افرة في القائمة. ع - - تصنيف البدائل المتو افرة إلى (بديل مهر- بديل غير مهر).

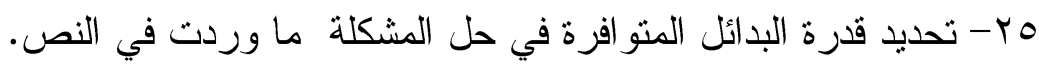
بr- تحديد نوع البدائل المثو افرة في حل مشكلة ما وردت في النص.

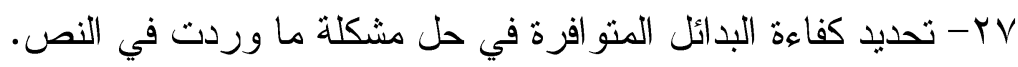
م ץ- إيجاد العو امل المشتركة بين البدائل المتو افرة. q و - إيجاد العو امل المختلفة بين البدائل المتو افرة. • س- الحيادية و البعد عن الذاتية في اختيار البدائل. اس- تحديد درجة التو افق بين الأهداف التي يحققها البديل والأهداف المرجوة. 
ץ"- تحديد مدى مناسبة استغلال البديل للإمكانيات المتاحة. بr- تحديد مدى مناسبة استغلال البديل للموارد المتاحة. ع - تحديد مدى مناسبة الظروف المحيطة للأخذ بالبديل المقترح. هr- تحديد مدى مناسبة الوقت للأخذ بالبديل المقترح. جس- تحديد مدى درجة المخاطرة التي ينطوي عليها كل بديل. rV التنبؤ بالنتائج المنرتبة على اختبار البديل دون غيره من البدائل. مب- المفاضلة بين البدائل المتو افرة . q - اختيار البديل الأكثر فعالية. • ع- العمل في مجموعات و المشاركة بطلب المساعدة الذهنية من الآخرين في إصدار

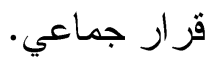

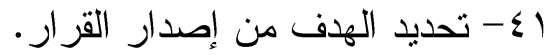
r بـ - التزيث و عدم الاستعجال عند إصدار القرار. ـ ــ عدم التأثر بقر ار ات الآخرين. 0ـ - تقديم الحجج و المبررات عند إصدار القرار. كצ

ع V - ثقويم القرار بتحديد نقاط القوة و التمسك بها، وتحديد نقاط الضعف ومحاولة تعديلها. ^乏 - تنفيذ القرار الصادر ثم متابعته. ثانياً: اختيار المحتوى: قامت الباحثة باختيار ثلاث دروس مناسبة للار اسة الحالية، بحيث تضمنت درسين من البرنامج المشترك (الثامن عشر: الثباب، و الدرس الثاسع عشر: الابتعاث و أحكامه و آدابه)، ودرس واحد من البرنامج التخصصي (الدرس الرابع: اللغة العربية، أهميتها و المحافظة عليها)، وتم وضع الأشطة التعليمية على كل درس لنشمل مهارات اتخاذ القرار التي ينبغي تتميتها لطلاب/طالبات المرحلة الثانوية (نظام المقررات). 


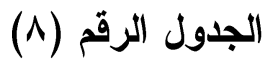

عنوان الدرس، المقرر الدراسي، المؤشرات التي تم تضمينها في الأنشطة

\begin{tabular}{|c|c|c|c|c|c|c|}
\hline مؤشرات الصدارة & 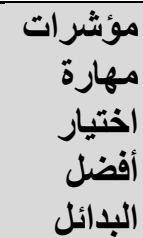 & مونشئرات & مونشر اثرة & مهوثرة ملثرات & الإثقافة & العنوان \\
\hline 1.61 & $\begin{array}{r}67 \\
61 \cdot 9\end{array}$ & $r_{6} T_{6}$ & 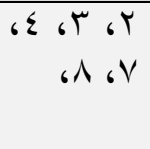 & $\begin{array}{c}6 Y \quad 61 \\
1 . V 6 \% \\
1.69\end{array}$ & التخصصنامج & ألالفيتها العربية، \\
\hline $\begin{array}{ll}6 & 61 \\
6 & 6 \\
6 & T_{6} \\
& V_{6} 7\end{array}$ & 1.69 & $\begin{array}{c}64 \\
69 \\
61 \\
61 \\
6\end{array}$ & $\begin{array}{l}6 Y \\
65 \\
6 \%\end{array}$ & $\begin{array}{l}6 Y \\
6 \quad 61 \\
6\end{array}$ & البرنـامتج & الشباب \\
\hline $\begin{array}{r}6961 \\
1\end{array}$ & 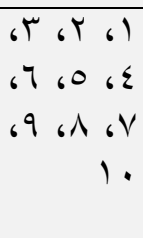 & $\begin{array}{lll}6 & 6 Y & 61 \\
60 & 6 \varepsilon \\
61 & 67, V \\
& 9\end{array}$ & $\begin{array}{lll}6 & 6 & 61 \\
67 & 0.6 & 6 \\
6 & 6 & 6 \\
1 . & 69\end{array}$ & $\begin{array}{ccc}6 & 6 \\
6 & 6 \\
6 & 6 \\
6 V & 676 \\
6 & 61 \\
& 1 .\end{array}$ & البرنـامتج & وآدابتهاث: أحكامه \\
\hline
\end{tabular}

ثالثاً: وضع الأشطة التعليمية:

تحددت أنشطة الدروس الثلاثة المختارة من مقرر الثقافة الإسلامية للمرحلة الثانوية "نظام

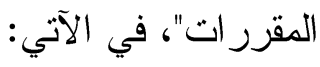

ا-الارس الأول: اللغة العربية، أهميتها والمحافظة عليها: تم وضع أنشطة تعليمية للارس و الذي بعنوان: اللغة العربية، أهميتها و المحافظة عليها، وفقاً للقائمة المعدة سابقا، وذللك لتنمية مهار ات اتخاذ القرار في نشاطين ، وهما كالآتي:

(1)

استعرض مدير المدرسة مستوى الطلاب في جميع فصول المرحلة الثانوية، فوجد تدنياً و اضحاً في مسنوى اللغة العربية في أحد الفصول، على الرغم من أن المعلم يبذل 
مجهوداً و اضحاً في تدريس المادةه. تعاون مع زملائك في اتخاذ القرار المناسب لحل هذه المشكلة، وذلك من خلال إتباع خطو ات منطقية ومشلسلة، وهي كالآتي: 1- تحديد أسباب المشكلة و العلاقة بين جوانبها، وجمع المعلومات المتعلقة بها ثم تلخيصها.

r- وضع تصور ات حول الحلول الممكنة. r- إعداد قائمة بالبدائل المناسبة لحل المشكلة، ووفقاً لمعايير تساعد على الحكم على هذه البدائل، ومن ثم اختيار البديل الأكثر فعالية. ب- تحديد درجة التوافق بين الاهداف، التي يحققها البديل والأهداف المرجوة، ومن ثم التطبيق السليم ومتابعته. (r) النشاط رقم بالتعاون مع مجموعتلك: حدد أسباب ضعف الاهنمام باللغة العربية و الكيد لها، ثم ضع الحلول المناسبة لها.

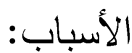
.-1 .$-r$ r الحلول: -1 .$-r$ -r 
رتب الحلول، من ثم اختار البديل الأكثر فعالية:

\begin{tabular}{|c|c|c|c|}
\hline الترتيب حسب الأفضلية & سلبياته & إيجابياته & رقم الحل \\
\hline & & & 1 \\
\hline & & & r \\
\hline & & & $r$ \\
\hline
\end{tabular}

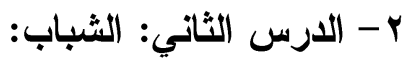

تم وضع أنشطة نعليمية للارس و الذي بعنوان: الثباب، وفقاً للقائمة المعدة سابقاً، وذللك لتنمية مهار ات اتخاذ القرار في نشاطين ، وهما كالآتي:

(1) النشاط رقم

قررت إدارة المدرسة توجيه دعوة للك للاشتر الك في ندوة سوف يتم تنظيمها خلال

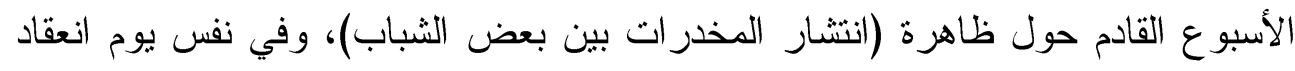
نلك الندوة، سوف ينم تنظيم رحلة علمية لزيارة محطة الأقمار الصناعية، ولقد فوجئت

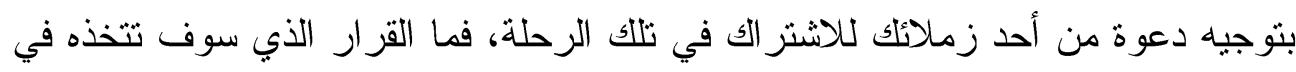

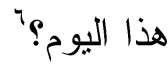

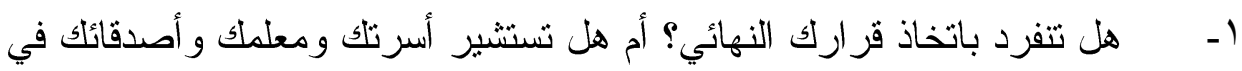

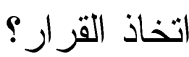
r- هل تفكر في الاشتر الك في الندوة وتسهم فيها بالحوار و الدناقشة، و اقتتر اح الحلول

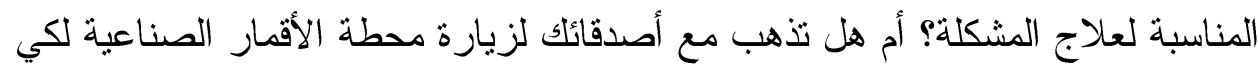

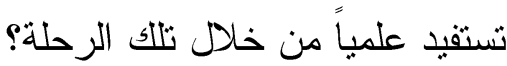

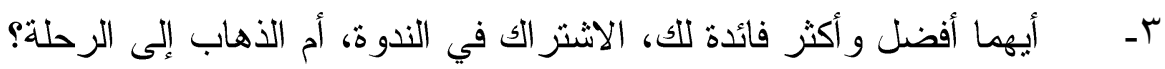
ع - هل يمكنك إيجاد العو امل المشتركة و المختلفة بين البديلين؟

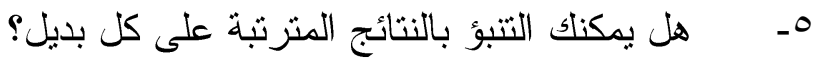
T- هل يمكنك تقديم المبررات و الحجج عند إصدار القرار الذي اتخذته ؟ 
النشاط رقمـ (r) يتعرض الثباب اليوم لهجمة شرسة بأشكال و أساليب منتوعة من خلال

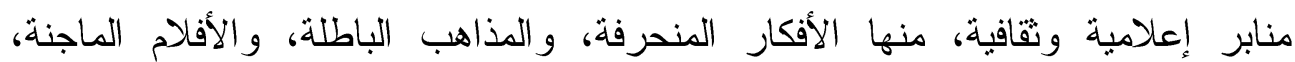

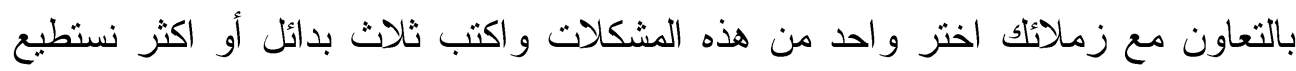
من بينها تخاذ قرار في كيفية حل هذه المشكلة، منبعاً الخطو ات الآتية:

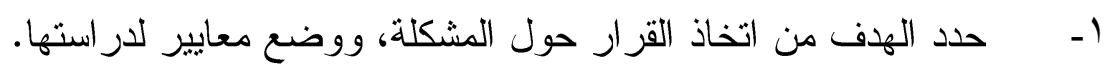
r- إعداد قائمة للبدائل المطلوبة، ووضع معايير للحكم عليها. r- المفاضلة بين البدائل و اختيار البديل الأكثر فعالية. ع- تقديم المبررات و الحجج عند إصدار القرار .

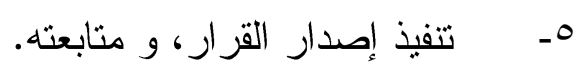
ب- الدرس الثالث: الابتعاث :أحكامه وآدابه: تم وضع أنشطة تعليمية للارس و الذي بعنوان: الابتعاث :أحكامه و آدابه، وفقاً للقائمة

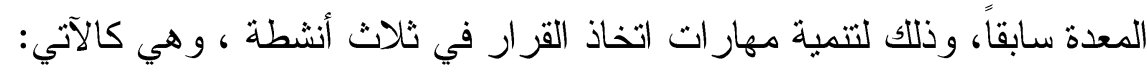

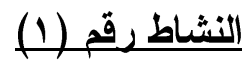

كثير اً ما نسمع اليوم عن مشاكل مبتعثين منهم من قرارتهم التسرب من الجامعة،

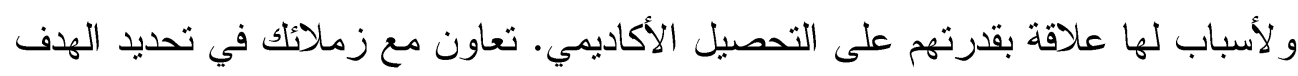

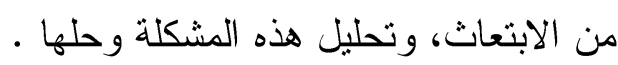

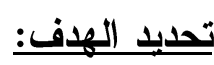

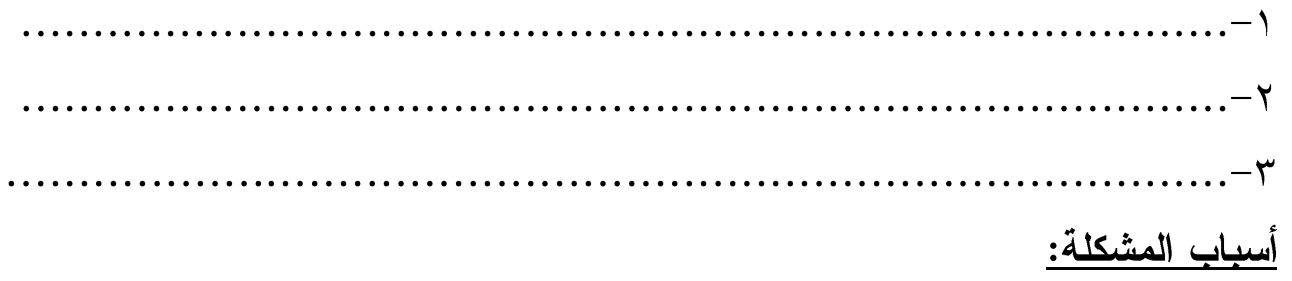

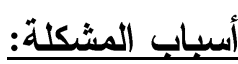




\section{وضع تصور واقعي ومنطقي لحل المشكلة:}

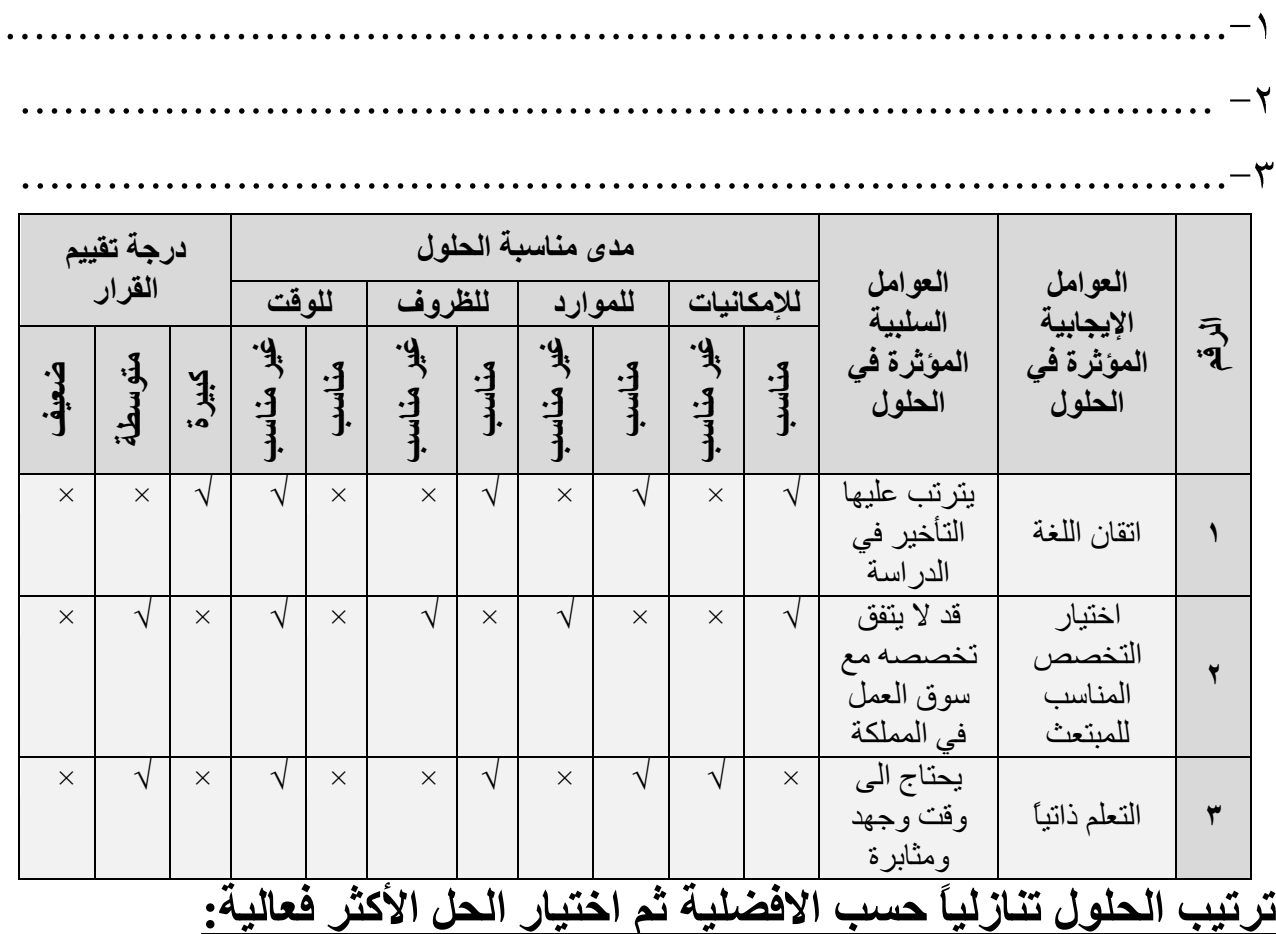

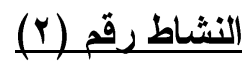

قرار الالتحاق بالابتعاث يترتب عليه تحديد مسار حياة الطالب العملية، وقرار الالتحاق

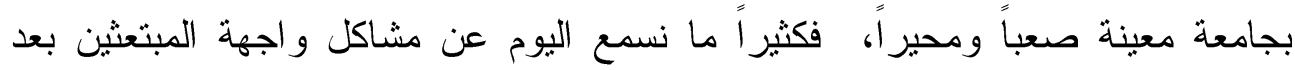
اختيار الجامعة، منها تدني مستوى كفاءة الجامعة المبتعث إليها، ومع تصنيف جامعة تونج

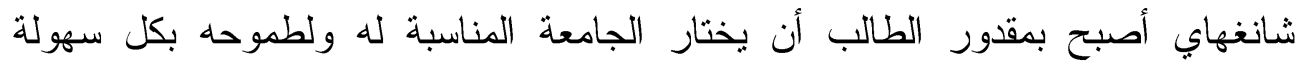
ويسر، حيث تتشر هذه الجامعة قائمة بأفضل .0 جامعة في شهر سبتمبر من كل عام. وتتضمن طريقة التصنيف أربعة معايير رئيسة هي (جودة التعليم، نوعية أعضاء هيئة

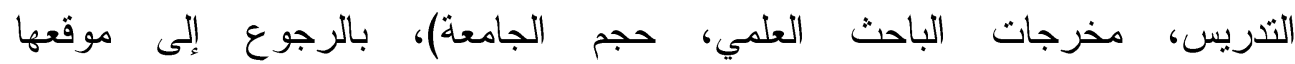

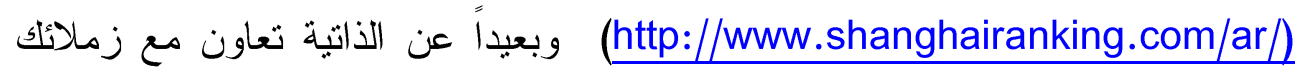
في المفاضلة بين الجامعات المنت افرة في القائمة لعامه ؟ أهـ، ثم متابعه القر ار في السنة

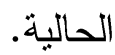




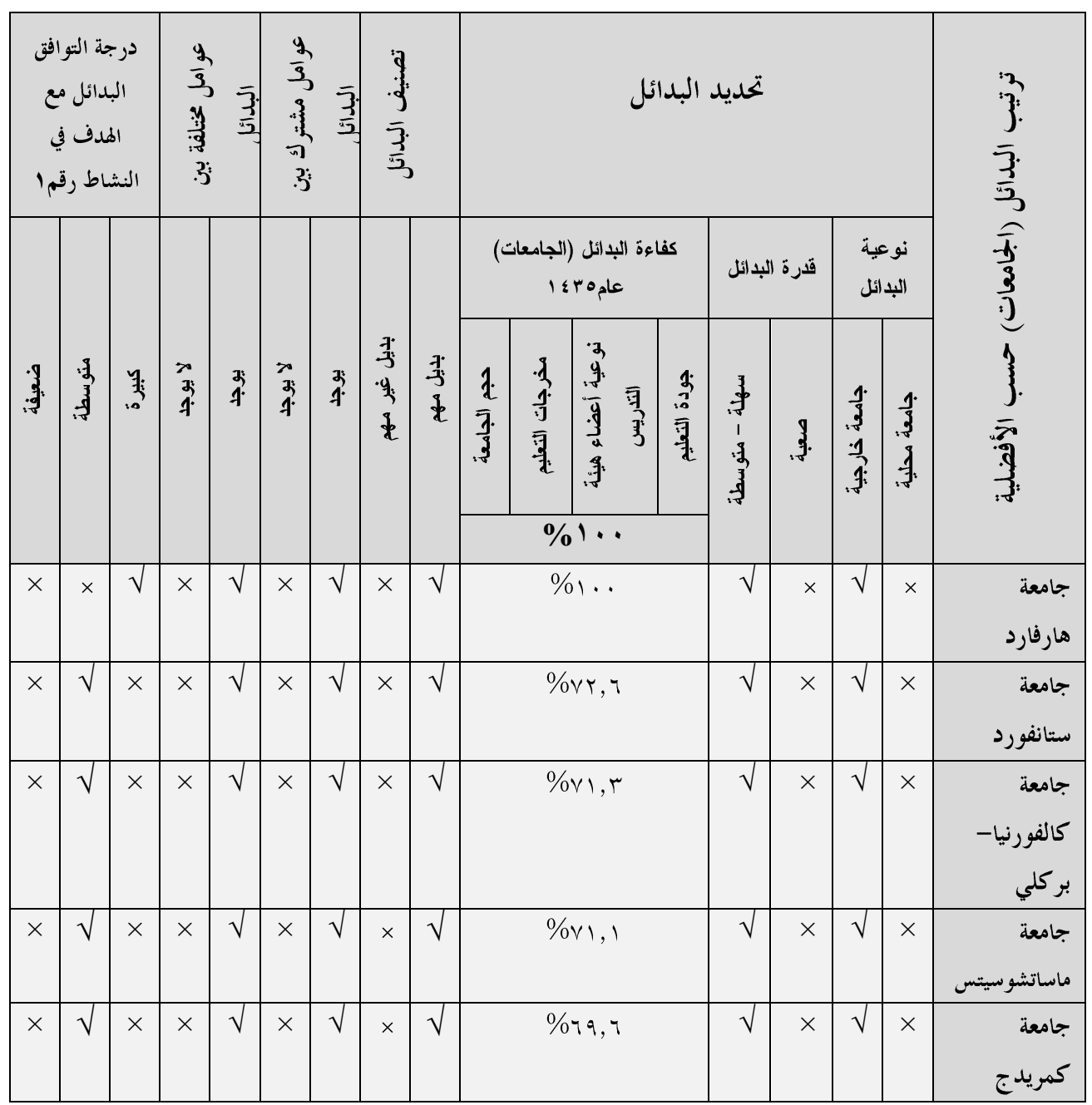

(r) نشاط رقمر

كثير أ ما نسمع اليوم عن قضايا مبتعثين منهم من قرارته أنه لا يستطيع الاستمرار في البعثة بعد عدة سنوات، و لأسباب ليس لها علاقة بقدتهم على التحصيل الأكاديمي،

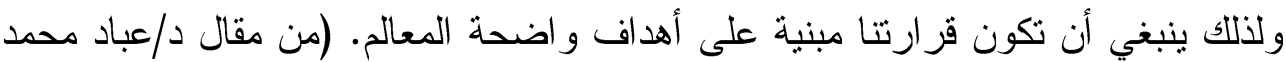
العباد في صحيفة الرياض الصادرة من مؤسسة اليمامة الصحفية). تعاون مع زملائك في الي لهي وصف هذه المشكلة، وفق المعايير الآتية: 


\begin{tabular}{|c|c|c|c|c|c|c|c|c|c|c|}
\hline \multicolumn{3}{|c|}{ دالتي بنطوي المخاطرة } & \multirow{2}{*}{ 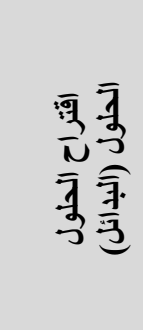 } & \multicolumn{2}{|c|}{ تصنيف المعلومات } & \multicolumn{2}{|c|}{ جوأب أسبابها- } & \multirow[b]{2}{*}{ أقواثياً } & \multirow[b]{2}{*}{ المعيــار } & \multirow[b]{2}{*}{ r } \\
\hline . & รู & 巽 & & के & $\begin{array}{l}3 \\
3 \\
3 \\
3 \\
3\end{array}$ & $\begin{array}{l}20 \\
3 \\
1 \\
y \\
\frac{9}{7}\end{array}$ & 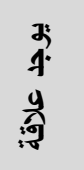 & & & \\
\hline$x$ & $\sqrt{ }$ & $x$ & ..........- & \multirow[t]{3}{*}{$x$} & \multirow[t]{3}{*}{$\sqrt{ }$} & \multirow[t]{3}{*}{$x$} & \multirow[t]{3}{*}{$\sqrt{ }$} & \multirow[t]{3}{*}{1} & \multirow[t]{3}{*}{ تأثير الصحبة. } & \multirow[t]{3}{*}{1} \\
\hline$\sqrt{ }$ & $x$ & $x$ & ......... ${ }^{r}$ & & & & & & & \\
\hline$x$ & $x$ & $\sqrt{ }$ & "ז......... & & & & & & & \\
\hline$x$ & $\sqrt{ }$ & $x$ & ..........- & \multirow[t]{3}{*}{$x$} & \multirow[t]{3}{*}{$\sqrt{ }$} & \multirow[t]{3}{*}{$x$} & \multirow[t]{3}{*}{$\sqrt{ }$} & \multirow[t]{3}{*}{$r$} & \multirow{3}{*}{ تعاملهم وناسن وطريقة } & \multirow[t]{3}{*}{$r$} \\
\hline$x$ & $x$ & $\sqrt{ }$ & ......... & & & & & & & \\
\hline$x$ & $\sqrt{ }$ & $x$ & ".......... & & & & & & & \\
\hline$x$ & $\sqrt{ }$ & $x$ & .......... & \multirow[t]{3}{*}{$x$} & \multirow[t]{3}{*}{$\sqrt{ }$} & \multirow[t]{3}{*}{$x$} & \multirow[t]{3}{*}{$\sqrt{ }$} & \multirow[t]{3}{*}{ r } & \multirow{3}{*}{ الشتخرة فية الغير } & \multirow[t]{3}{*}{$r$} \\
\hline$\sqrt{ }$ & $x$ & $x$ & $\ldots . . . .$. - $^{r}$ & & & & & & & \\
\hline$x$ & $x$ & $\sqrt{ }$ & ......... & & & & & & & \\
\hline
\end{tabular}

رابعاً: اختيار طرائق التدريس:

يختار المعلم/المعلمة من الطرائق ما يتتاسب مع الأنشطة، ويحقق أهداف التصور المقترح: 1- استر اتيجية العصف الذهني: من أجل التفكير في عدد البدائل. r- استراتيجية حل المشكلات: من أجل التفكير و البحث و التقصي و التشاؤل وجمع المعلومات وتفسير ها و استنتاج الحلول الممكنة وتجريبها للوصول إلى حل للمشكلة. ب- استر اتيجية الخر ائط الذهنية: من أجل تتظيم الأفكار و البدائل بشكل بسهل على الطالب اختيار ها وتتظيم الأولويات في حلها. ع- استر اتيجية هليدا تابا: من أجل التفكير و التأمل وحل التهلئ المشكلات، والتوصل إلى حلول للمشكلات وقياسها و تقو يمها. 0- استر اتيجية القبعات الست: من أجل التفكير في الجوانب المختلفة لكل بديل. 
צ- اسثر اتيجية الاستقصاء: من أجل إثارة تفكير الطالب/ الطالبة في مشكلات ومواقف من و اقع الحياة، ووضع الفروض. لمان.

- V التعلم التعاوني: من أجل الوصول إلى قروار جماعي.

1- برنامج الكورت: من أجل التفكير في القرارات، والبدائل والاحتمالات، و اعتبار جميع

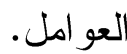

خامساً: اختيار أساليب التقويم:

يختار المعلم/المعلمة من أساليب الثقويم ما يتتاسب مع الأنشطة، ويحقق أهداف

التصور المقترح.

1- التقويم المبدئي: يهدف إلى معرفة ما لدى الطلاب/الطالبات مما بر اد تقويمه لهم. أ)/المناقشة الجماعية.

ب) الثقارير الذاتية. ج) الاختبار ات الثفهية. r- التقويم التكويني: يكون خلال سير الدرس.

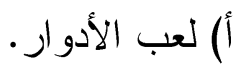
ب) أوراق عمل. ج) بطاقة الملاحظة. ب- التقويم الختامي: يهدف إلى تأكيد على استيعاب ما تعلمه الطالب/الطالبة.

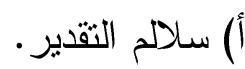
ب) القو ائم الشطب. ج) عينات أعمال و انجاز ات الطلاب/ الطالبات. وبذلك تكون الباحثة قد أجابت على السؤال الثالث من أسئلة الدراسة المتعلقة بتتمية مهار ات اتخاذ القر ار اللازم تتميتها في مقرر الثقافة الإسلامية للمرحلة الثانوية (نظام

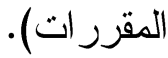




$$
\text { التوصيات: يمكن تقديم عدد من التوصيات، وهي كالآتي: }
$$

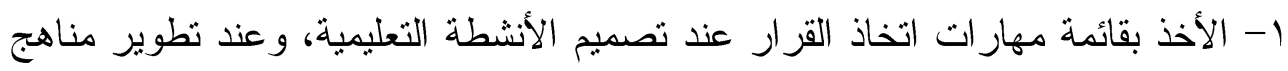

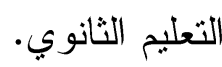
r- لفت انتباه مطوري المناهج بأهمية تضمين مهارات اتخاذ القرار في أنشطة مقرر الثقافة الإسلامية للمرحلة الثانوية. r- إعداد برنامج تدريبي للمعلمين؛ لتدريبهج على تتمية مهارات اتخاذ القرار، وكيفية إكسابها للطلاب المرحلة الثانوية. ع-الاستفادة من التصور المقترح عند تطوير مقرر الثقافة الإسلامية للمرحلة الثانوية . 
قائمة المر اجع

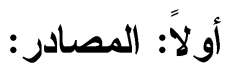

القر آن الكريم.

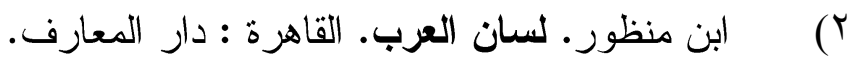

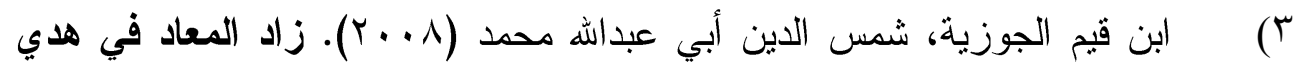
خير العباد. دمشق : مؤسسة الرسالة.

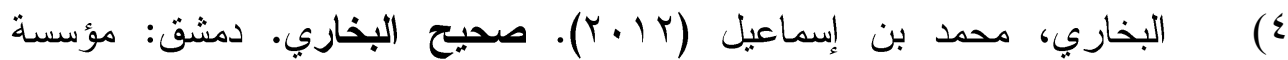
الرسالة.

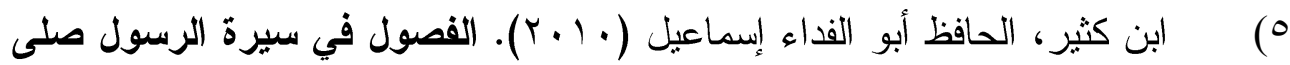
الله عليه وسلم. دمشق: دار الكلم الطبب.

الدمشقي، الإمام أبي زكريا يحيى النووي (9 . . ب). رياض الصالحين. لبنان : مؤسسة الرسالة

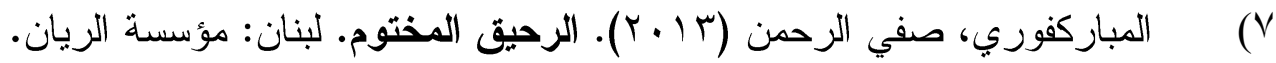

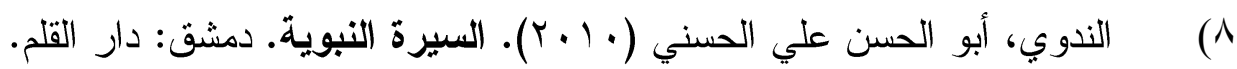

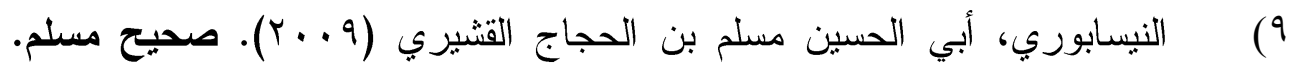
دمشق: مؤسسة الرسالة.

ثانياً: المراجع العربية :

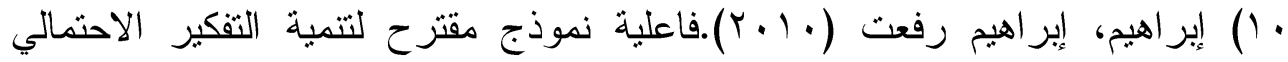
ومهارات اتخاذ القرار لدى تلاميذ المرحلة الابتدائية. مجلة دراسات في المناهج وطرق التدريس. 99 - 9109 (109. (1) إبر اهيم، عبداله علي محمد وحسن، محمد أمين (ع ...r، يوليو). أثر استراتيجية مقترحة قائمة على العصف الأهني واتخاذ القرار في تدريس الأحياء على تنمية

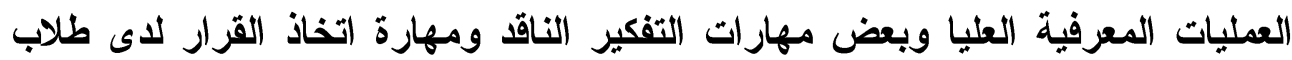


المرحلة الثانوية بالمملكة العربية السعودية. بثث مقدم إلى المؤتمر العلمي الساد عشر - تكوين المعلم. القاهرة، مصر . r ( أبو جادو، صالح محمد ونوفل، محمد بكر (Y..V). تعليم التفكير: النظرية والتطبيق، عمان: دار المسيرة.

r ( أبو عو اد، فريال محمد و الثلبي، إلهام علي و عبد، إيمان رسمي و عشا، انتصار

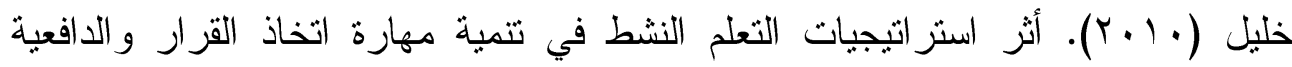
للتعلم لاى طالبات كلية العلوم التربوية التابعة لوكالة الغوث. مجلة الزرقاء للبحوث

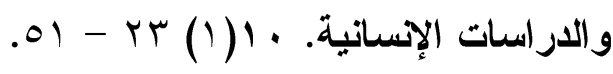

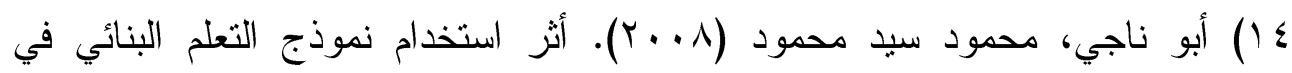
تدريس العلوم على التحصيل وتتمية مهارات اتخاذ القرار و الميول العلمية لدى تلاميذ

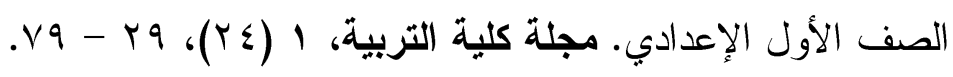

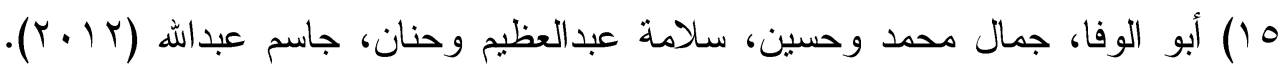

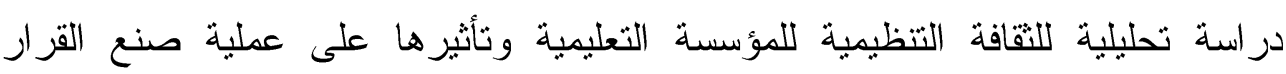

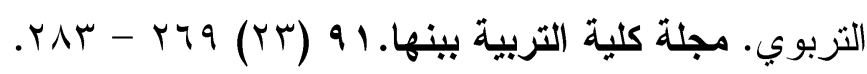

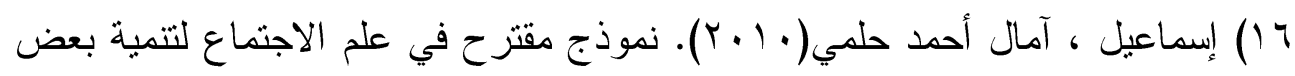
مهار ات ما ور اء المعرفة و القدرة على اتخاذ القرار نحو المشكلات المجتمعية المعاصرة المردية

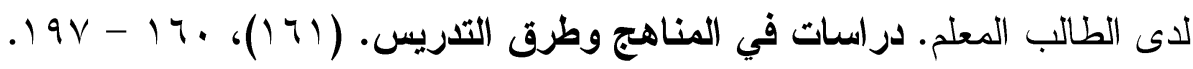

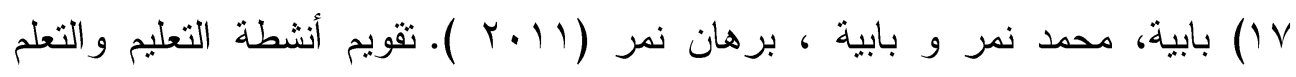

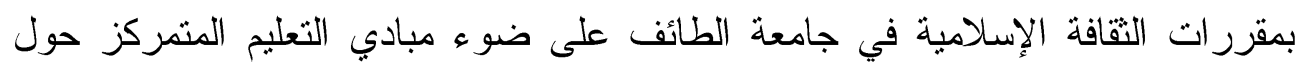

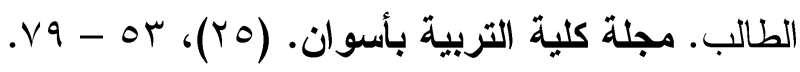

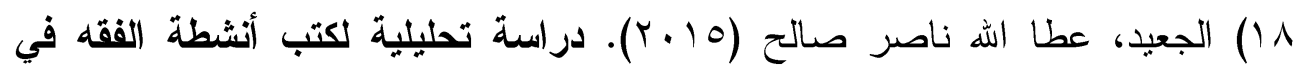
المرحلة المتوسطة في ضوء نظرية الأكاءات المتعددة. رسالة ماجستير غير منشورة، جامعة الطائف، الطائف، المملكة العربية السعودية. 
9 () الجديبي، رأفت محمد (•rع (). تصور مقترح لتنمية المهار ات الحياتية لاى طلاب المرحلة الثانوية في ضوء التحديات والاتجاهات المعاصرة روية تربوية إسلامية. رسالة دكتور اه غير منشورة، جامعة أم القرى، مكة المكرمة، المملكة العربية السعودية.

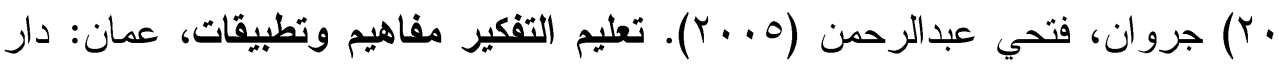
الفكر -

(Y) الجهني، علي عيد أحمد (Yr乏 ( ). درجة إسهام كتاب الحديث والثقافة الإسلامية في

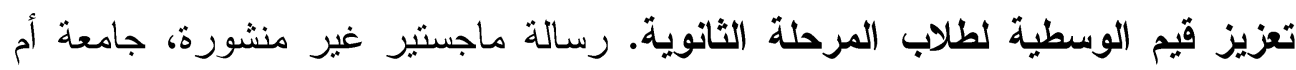
القرى، مكة المكرمة ،المملكة العربية السعودية.

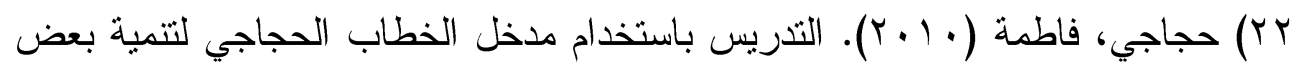
مهار ات الدر اسة و عادات العقل لدى الطالبة المعلمة شعبة التاريخ. مجلة الجمعية التربوية

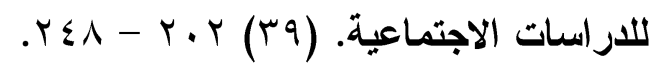

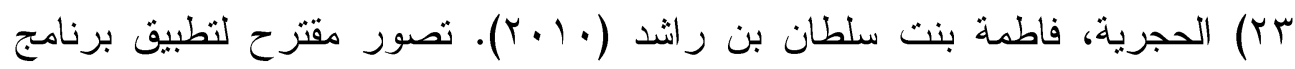

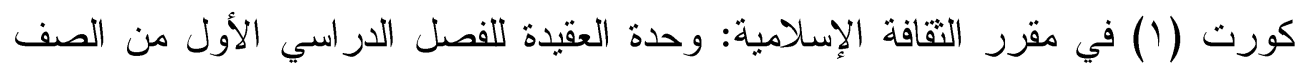

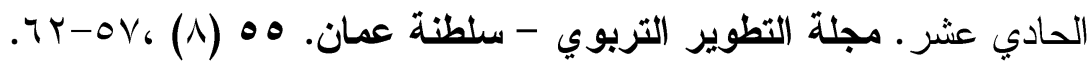

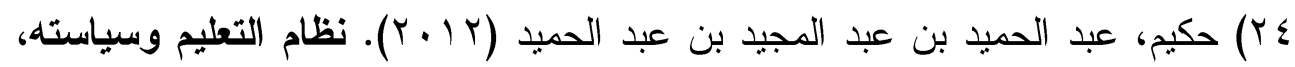
القاهرة: مكتبة إيثز الك.

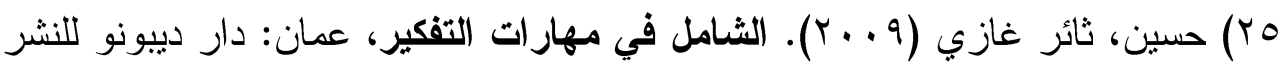

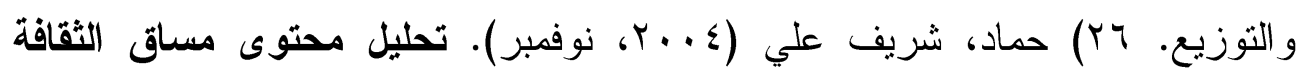
الإسلامية في الجامعات الفلسطينية بقطاع غزة في ضوء قضايا معاصرة. بحث مقدم إلى هلى

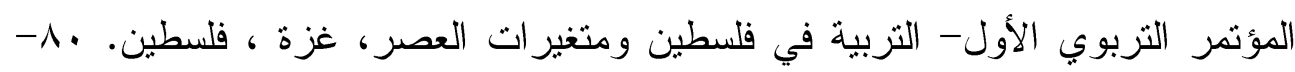
.1 .9

(YV حماد، عادل رسمي و معبد ،علي كمال (؟ . . Y).أثز استخدام نموذج التعلم البنائي الاجتماعي في تدريس الدراسات الاجتماعية على التحصيل وتتمية مهار ات اتخاذ القرار

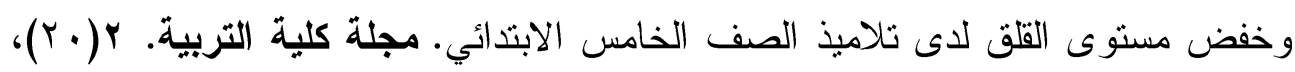




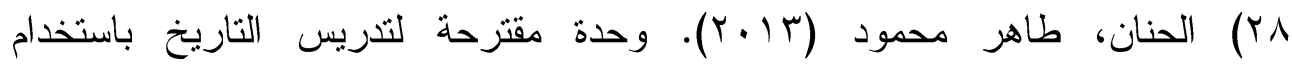
استراتيجيات التفكير المتشعب في تتمية مهار ات اتخاذ القرار و الوعي التاريخي بتاريخ

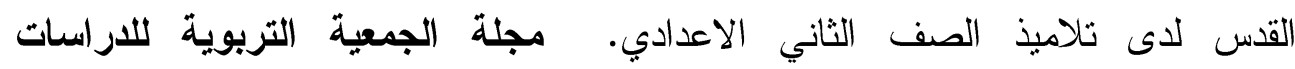

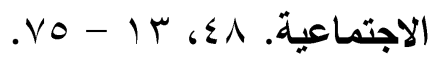

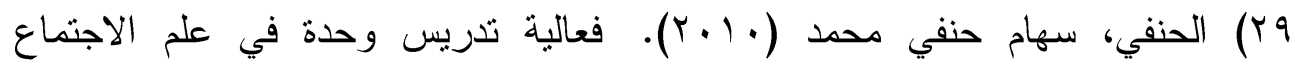
باستخدام استر اتيجية حل المشكلات لإكساب مهار ات اتخاذ القرار وتتمية التحصيل لدى

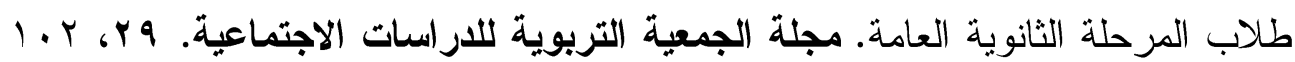
.107 -

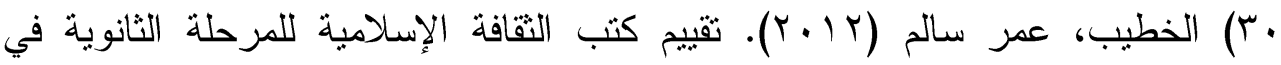
الأردن في ضوء الأهداف التي تحقق الضرورات الخمس. مجلة جامعة الملك سعود-

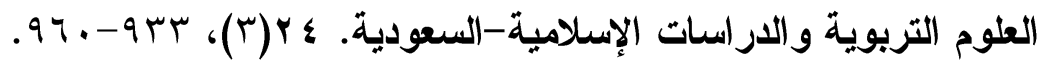

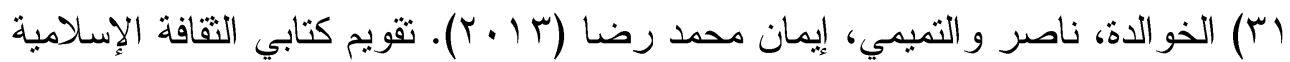
للمرحلة الثانوية في ضوء معايير الجودة الثاملة. مجلة المنارة للبحوث والدراسات-

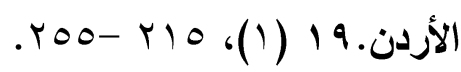

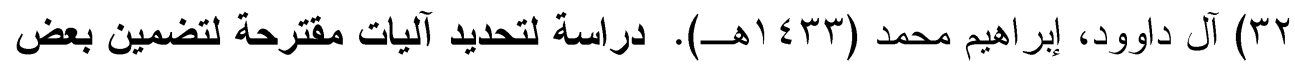
المهارات الحياتية في مناهج التربية الإسلامية بالمرحلة الثانوية من وجهة نظر المختصين والممارسين. رسالة ماجستير غير منشورة، جامعة أم القرى، مكة المكرمة ، المملكة العربية السعودية.

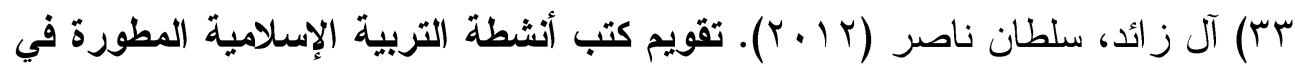
المرحلة الابتدائية في ضوء تنمية مهارات التفكير الابداعي. رسالة ماجستير غير منشورة: جامعة الطائف، المملكة العربية السعودية.

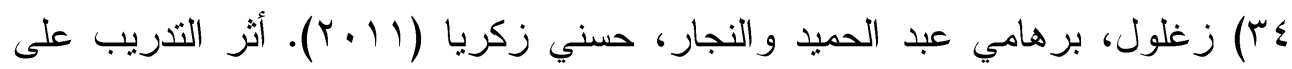
بعض استر اتيجيات ما ور اء المعرفة في تتمبة التحصيل الدراسي ومهار ات اتخاذ القرار و الدافعية للتعلم لاى طلاب المدارس الثانوية التجارية. مجلة كلية التربية بالإسكندرية. 1 $.411-10 \cdot 6(r)$ 
هب) زيتون، حسن حسين (ب. (Y). تعليم التفكير روئة تطبيقية في تنمية العقول المفكرة. القاهرة: عالم الكتب.

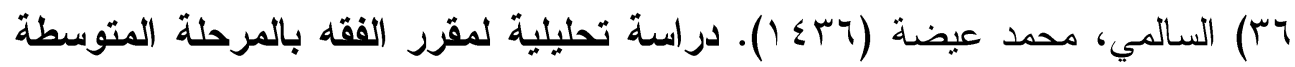
في ضوء مهارات التفكير الناقد. رسالة ماجستير غير منشورة: جامعة الطائف، الطائف، المملكة العربية السعودية.

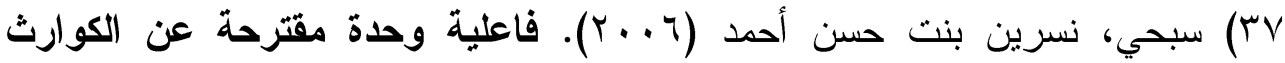
الطبيعية في تنمية اتخاذ القرار والاتجاه نحو الكوارث لاى تلميذات الصف الثاني متوسط بمدينة مكة المكرمة. رسالة دكتور اه غبر منشورة، جامعة أم القرى، مكة المكرمة ،المملكة العربية السعودية.

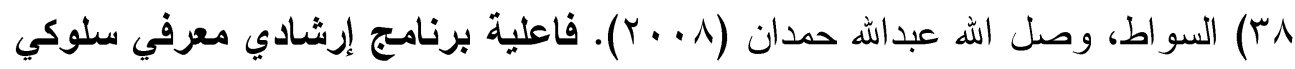

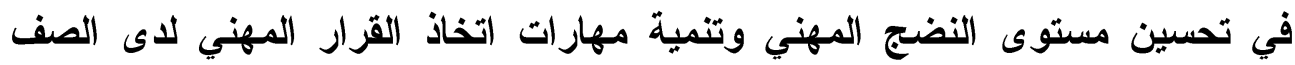
الأول الثانوي بمحافظة الطائف. رسالة دكتور اه غير منشورة: جامعة أم القرى، المملكة العربية السعودية.

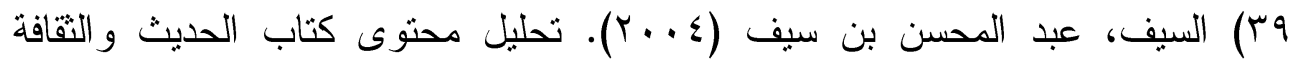
الإسلامية لطلاب الصف الثالث الثانوي في ضوء أهداف سياسية التعليم المملكة العربية

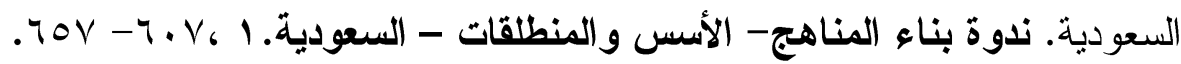

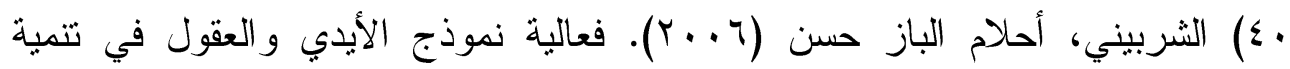

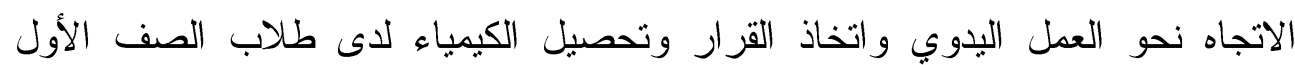

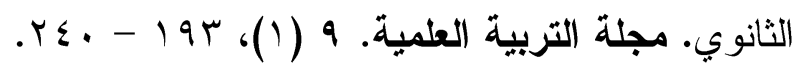

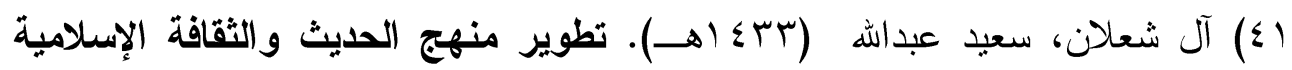

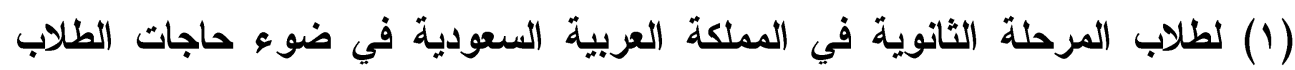

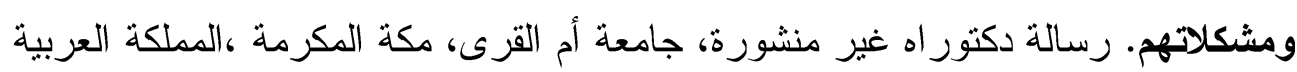
السعودية. 


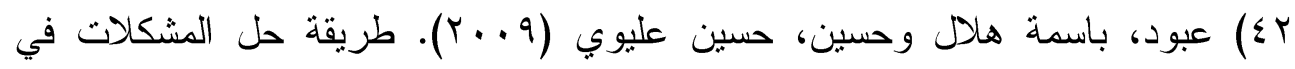
ظلال التربية الإسلامية والإفادة منها في تدريس العلوم الثرعية. مجلة كلية التربية. $.10-0 V_{6}(\varepsilon)$

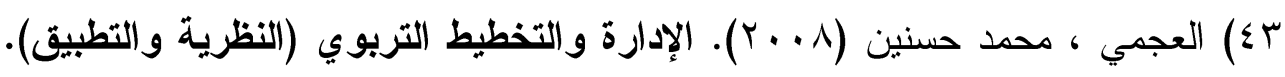
عمان : دار المسيرة.

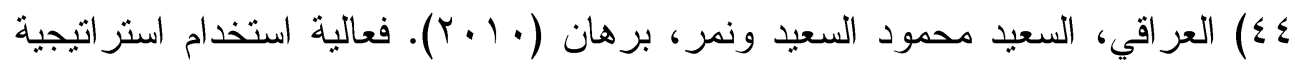
حل المشكلات في تدريس مبحث الثقافة الإسلامية في تتمية القدرة على حل المشكلات

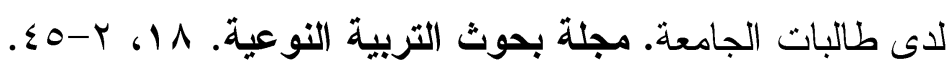

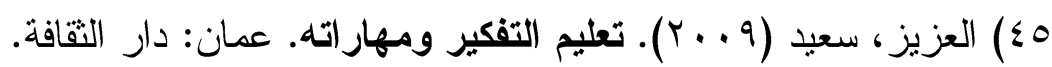

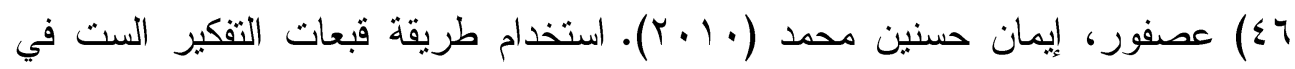
تجنب أخطاء التفكير و تتمية مهارة اتخاذ القرار لاى طلاب الصف الثالث الثانوي في

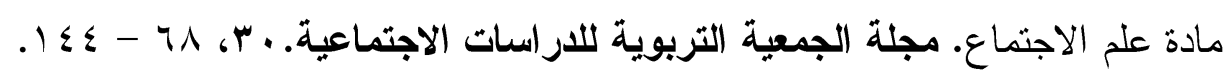
SV تدريس الجغر افيا على تتمية التقكير التأملي واتخاذ القرار لاي طلاب الصف الصف الأول

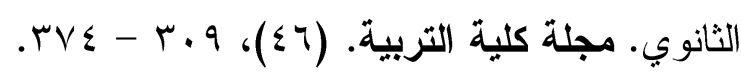

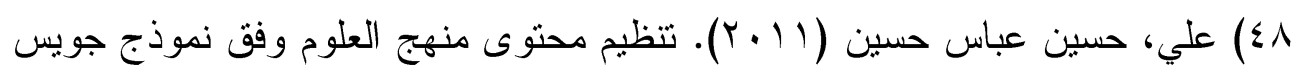
وويل \&W W. J لمعالجة المعلومات وفاعليته في تتمية المفاهيم العلمية ومهار ات اتخاذ القرار و التفكير الاستذلالي لدى تلاميذ الصف الخامس الابتدائي في المملكة العربية

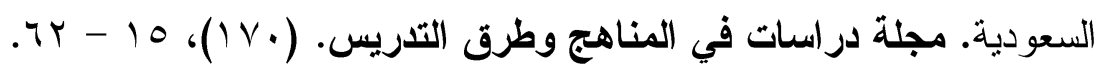

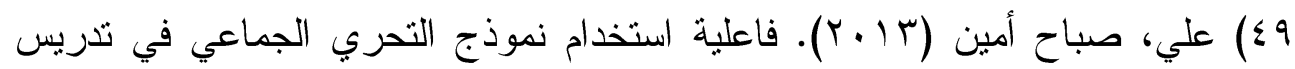
القضايا الاجتماعية على تتمية عادات العقل ومهارة اتخاذ القرار لدى الطالبة معلمة ،الفلسفة والاجتماع .مجلة الجمعية التربوية للاراسات الاجتماعية. ( 
•0) علي، و ائل عبد الله محمد (T . . Y). أثز استخدام استر اتيجية مقترحة في تحصيل الرياضيات وتتمية مهارات اتخاذ القرار لدى تلاميذ الصف الخامس ابتدائي. مجلة تريويات الرياضيات. (9)، ع ا 1 (0) عمر ان، خالد عبد اللطيف محمد (1 ( . ب). أثر استخدام استراتيجية التعلم التعاوني في تدريس الاراسات الاجتماعية على التحصيل المعرفي لاى تلاميذ الصف الثاني الإعدادي وتنمية وعيهم بيعض المشكلات الاقتصادية المحيطة بهم. رسالة ماجستير غير منشورة: جامعة جنوب الوادي، سوهاج، جمهورية مصر العربية.

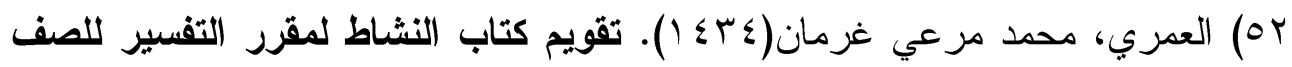
الأول المتوسط في ضوء معايير الجودة الثاملة. رسالة ماجستير منشورة جامعة الامام محمد بن سعود الإسلامية. الرياض، المملكة العربية السعودية.

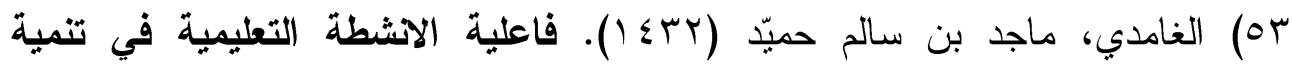
المهارات الحياتية في مقرر الحديث لطلاب الصف الثالث المتوسط. رسالة ماجستير غير منشورة: جامعة الامام محمد بن سعود الإسلامية، الرياض، المملكة العربية السعودية. ع) الفقي، إبر اهيم (• ( • ب). فن اتخاذ القرار. مصر : دار الر اية. 00) لافي، سعيد عبداله و الجغيمان، محمد (؟ . . ب). برنامج مقترح في الثقافة الإسلامية لطلاب المرحلة الثانوية في ضوء احتياجاتهم التعليمية. مجلة القراعة والمعرفة. (rV)، $. Y \cdot \Sigma-17 r$ به) لافي، فتحية علي حميد (11 (Y). فاعلية برنامج مقترح في تدريس مادة التاريخ قائم على عادات العقل لتمية مهار ات اتخاذ القرار لاى تلاميذ المرحلة الاعدادية. مجلة

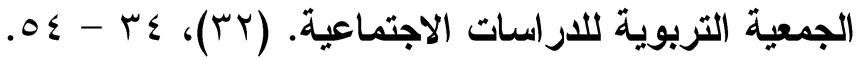
(OV ) المالكي، ريم بنت مصلح بن صالح (Y (Y). دراسة تحليلية لمحتوى مقرر الثقافة الإسلامية في جامعة الطائف في ضوء القيم الأخلاقية اللازمة لمواجهة تحديات العولمة الثقافية.رسالة ماجستير غير منشورة: جامعة الطائف، الطائف، المملكة العربية 


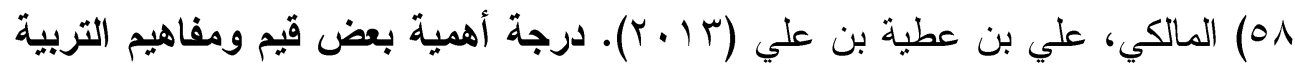
المهنية وآليات تضمينها في مقررات الحديث والثقافة الإسلامية بالمرحلة الثانوية. رسالة ماجستير غير منشورة، جامعة أم القرى، مكة المكرمة، المملكة العربية السعودية.

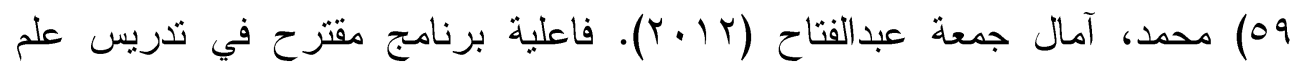
الاجتماع باستخدام التعلم الخدمي على تنمية المسئولية الاجتماعية و مهارات اتخاذ القرار لدى الطلاب المعلمين شعبة الفلسفة و الاجتماع. مجلة الجمعية التربوية للاراسات

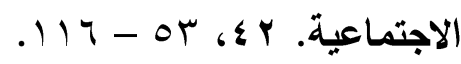

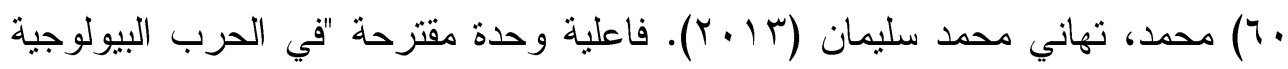
باستخدام مدخل التحليل الأخلاقي في تتمية القدرة على اتخاذ القزار وبعض مهارات

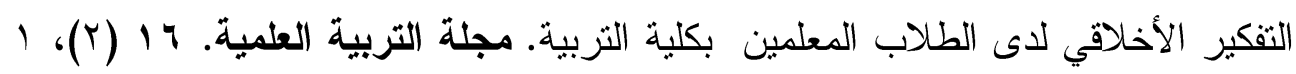
.rY -

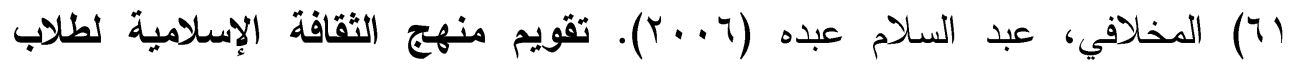
الجامعات اليمينة في ضوء حاجاتهم ومتطلبات عصر العولمة، أطروحة دكتوراه غير منشورة: جامعة عين شمس، القاهرة، الجمهورية مصر العربية.

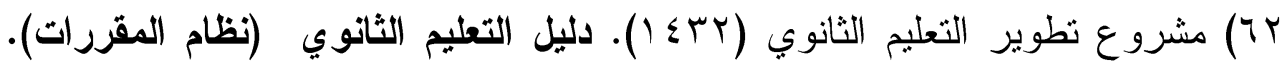
الرياض: وز ارة التزبية و التعليم.

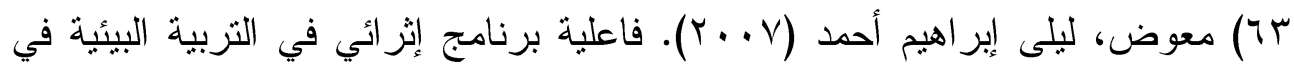

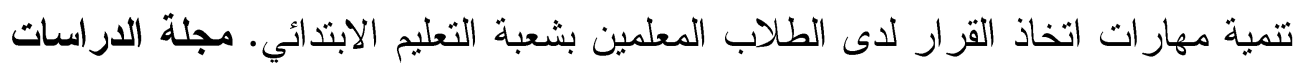

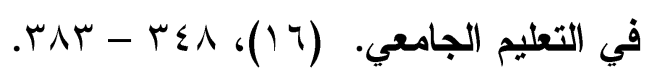

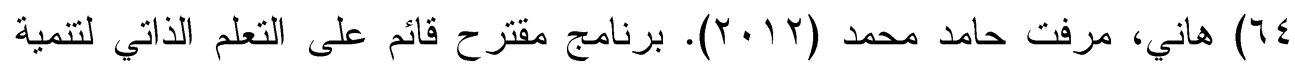
مفاهيم المعلوماتية الحيوية واتخاذ القرار لدى معلمي الأحياء بالمرحلة الثانوية. مجلة

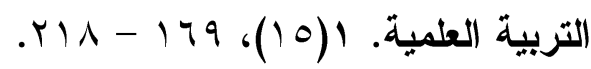

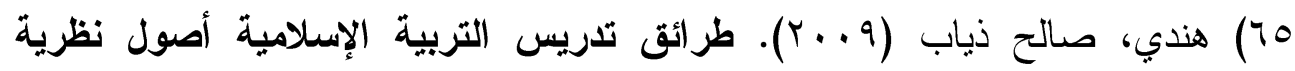
ونماذج وتطبيقات عملية. عمان: دار الفكر . 
77) وزارة التزبية و التعليم (7 اع ()). سياسة التعليم في المملكة العربية السعودية. الرياض: وزارة التربية و التعليم.

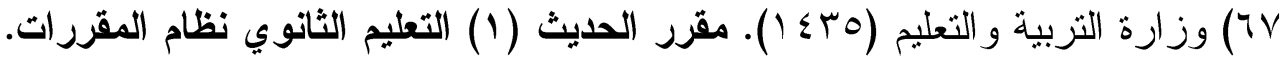
المملكة العربي السعودية، الرياض: وزارة التربية و التعليم.

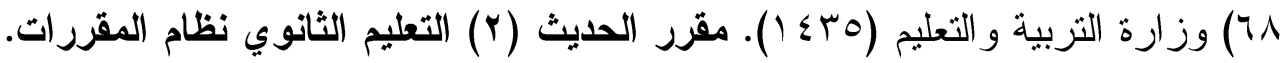
المملكة العربي السعودية، الرياض: وزارة التربية و التعليم.

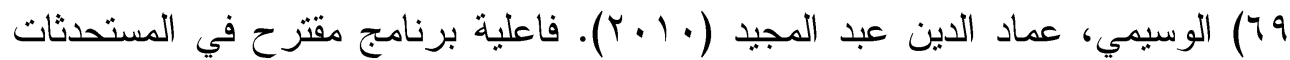
البيولوجية على التحصيل وتتمية مهار ات اتخاذ القزار و الاتجاه نحو هذه المستحدثات لاى لئ برلي

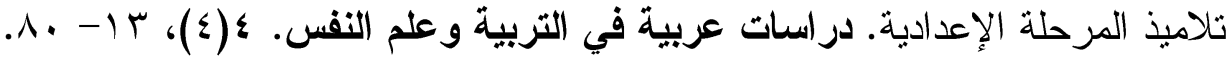

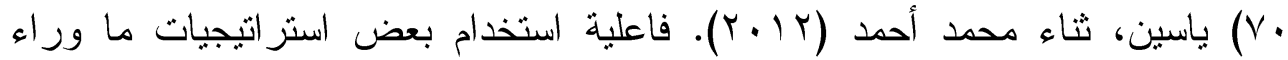

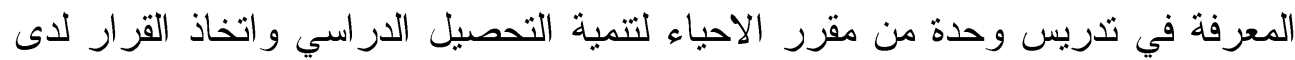

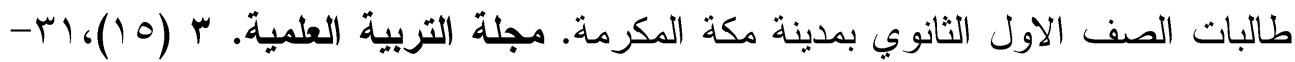

ثالثاً: المواقع الاككترونية:

(V) الغامدي، ماجد بن سالم حميّد (11 • Y، ابريل). مدخل عن تنمية المهارات الحياتية

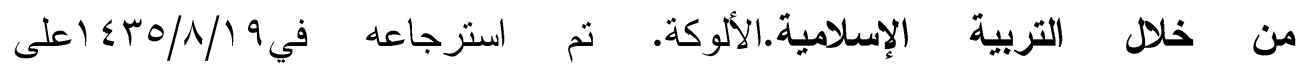
الر ابط./4ww.alukah.net/Authors/View/social/4274

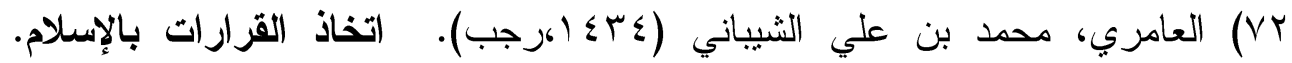

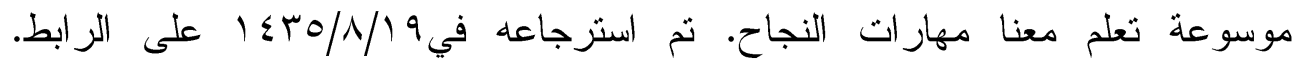
http://www.sst5.com/readArticle.aspx?ArtID=1258\&SecID=24 


\section{رابعاً: المراجع الأجنبية :}

73) Dieruf, K. (2004). Ethical decision-making by students in 33, 24-.physicaland occupational therapy. Journal of Allied Health

30.

74) Mjelde, J.W.; Litzenberg, K.K.; Lindner, J.R. (2011) .Cognitive Development Effects of Teaching Probabilistic Decision Making to Middle School Students. Journal of Natural Resources and Life 40, 36-44..Sciences Education

75) Rowland, Karen D. (2004). career decision -Making Skills Of High School Students in The Bahamas. Journal of Caree Development , (31)1,1-13. 76) Switzer, A. C. (2009). Assessing changes in high school students' environmental decision-making skills: Some methodological contributions. (Unpublished doctoral dissertation, University of Michigan), Available from ProQuest. (3392795). 
"An Evaluation study for the Islamic culture course for the secondary school in the light of the Developing Decision-making skills"

Search unsheathed from the Master

Prepared by the researcher / Nawal al-Maliki Ateeq Raddad Researcher MA in Curriculum and Teaching Islamic Studies

\section{Abstract}

The study aimed to reveal the extent of the decision to include Islamic culture at the secondary school level for decision-making skills, This study relied on the descriptive and analytical approach, and consisted appointed activities rapporteur Islamic culture at the secondary school level, and used two tools: A list of the skills of decision-making, and form analysis

following results:

1-That the emphasis activities of Islamic culture (Joint program), took into account the skills of problem identification rate of $(66.28 \%)$, while the activities of the (Specialist program), a rate of $(55.13 \%)$.

2-That the emphasis activities of Islamic culture (Joint program), took into account the skills of information gathering at a rate of $(25.58 \%)$, while the activities of the (Specialist program), a rate of $(23.08 \%)$.

3 -That the emphasis activities of Islamic culture (Joint program), took into account the skills of identifying alternatives at a rate of $(3.49 \%)$ while the activities of the (Specialist program), a rate of (12.82\%).

4-That the emphasis activities of Islamic culture (Joint program), a rate of $(1.16 \%)$, while the activities of the (Specialist program), a rate of $(2.56 \%)$.

5-That the emphasis activities of Islamic culture (Joint program), a rate of $(3.49 \%)$, while the activities of the (Specialist program) , a rate of $(6.41 \%)$.

In light of the findings, there are several recommendations, the need to develop the course of the Islamic Culture through the observance included for decision-making skills, and take advantage of the proposed perception rapporteur when developing Islamic culture at the secondary school level to address shortcomings. 


\title{
قائمة الملاحق
}

\section{الملدق رقم(1)}

قائمة بمهارات اتخاذ القرار

اللازم تضمينها في مقرر الثقافة الإسلامية للمرحلة الثانوية

( في صورتها الأولية)

\author{
المملكة العربية السعودية \\ وزارة التعليم العالي \\ جامعة الطائف \\ كلية التربية \\ قسم المناهج وتكنولوجيا النعليم
}

سلمه الله

| سعادة | - مادم السلام عليكم ورحمة الله وبركاته:

تقوم الباحثة /نو ال عتيق رداد المالكي بإجر اء دراسة متطلبات الحصول على درجة الماجستير في مناهج وطر ائق تدريس التزبية الإسلامية، بعنوان(دراسة تقوديمية لمقرر

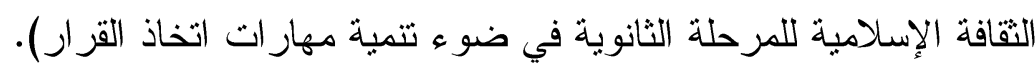
ومن متطلبات الدراسة بناء قائمة بمهارات اتخاذ القرار اللازمة لطلبة المرحلة

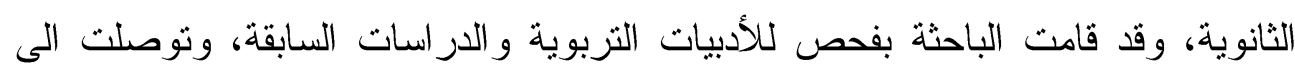

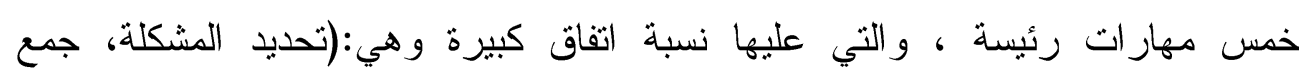
المعلومات، تحديد البدائل، اختيار أفضل البدائل، و إصدار القرار)

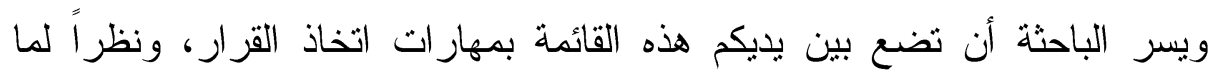
تتمتعون به - حفظكم الله- من خبرة في هذا المجال، يطيب للباحثة من سعادنكم التكرم

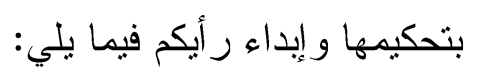

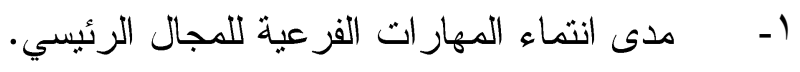
r- سلامة الصباغة اللغوية لهذه المهار ات. 


$$
\text { r- إضافة وحذف ما ترونه صالحاً لهذه الدر اسة. }
$$

علماً بأن ر أيكم سيكون له أثر كبير في نجاح هذه الدر اسة وتحقيق أهدافها. كما نؤكد لكم بأن البيانات التي تحددونها لن تستخدم إلا في أغر اض البحث العلمي فقط. شاكرين

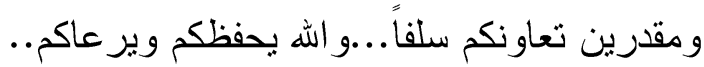

الباحثة/ نو ال عتيق المالكي

أولاً: البيانات الأساسبة:

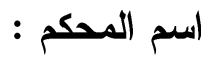

الدرجة العلمية :

بكالوريوس

ماجستيز

دكتور اه

عدد سنوات الخبرة:

أقل من خمس سنوات

أقل من عشر سنوات

أكثر من عثر سنوات

العمل الحالي:

التخصص العلمي :

جهة العمل:

طريقة التواصل عند الحاجة:

البريد الإلكتروني :

الههاتف :

ملاحظه الرجاء التكرم بكتابة المعلومات الثخصية ، وذلك لتضمينها بالملحق الخاص بييانات المحكمين

ولكم جزيل الشكر. 
قائمة بيهار ات اتخاذ القرار اللازم تضمبنها لمقر الثقافة الاسلامبية في صورتها الأولية

\begin{tabular}{|c|c|c|c|c|c|}
\hline \multicolumn{2}{|c|}{ صياغتها } & \multicolumn{2}{|c|}{ مدى الانتماء } & \multirow{2}{*}{ مهارات اتخاذ القرار اللازمة لطلبة المرحلة } & \multirow{2}{*}{ r } \\
\hline تعدل إلى & سليمة & لا تنتمي & تنتمي & & \\
\hline \multicolumn{6}{|c|}{ أ) مهارة تحديد المشكلة: } \\
\hline & & & & 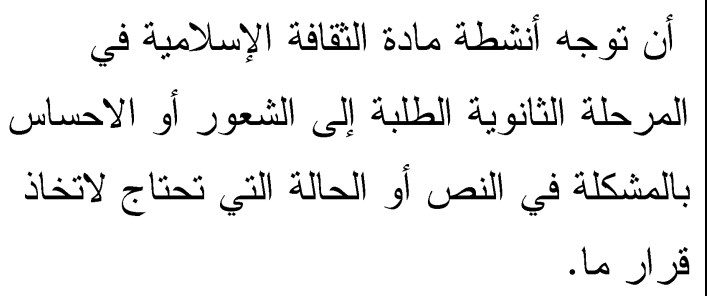 & -1 \\
\hline & & & & 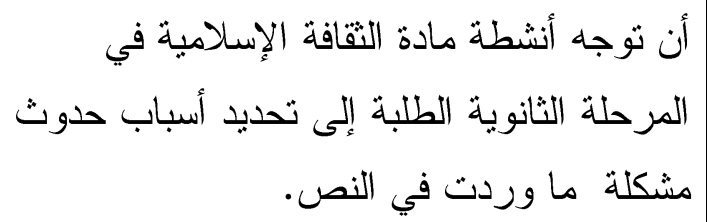 & $-r$ \\
\hline & & & & 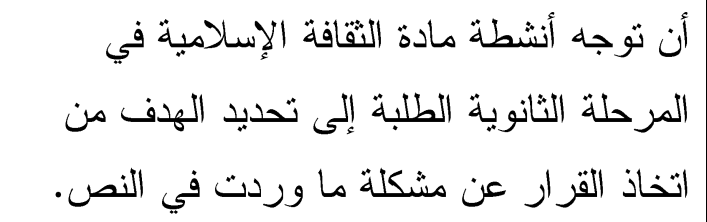 & $-r$ \\
\hline & & & & 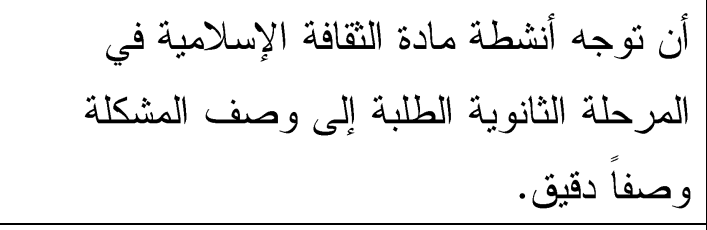 & $-\varepsilon$ \\
\hline & & & & 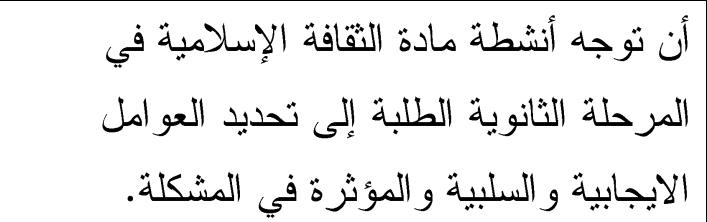 & -0 \\
\hline & & & & أن توجه أنشطة مادة الثقافة الإسلامية في & -4 \\
\hline
\end{tabular}




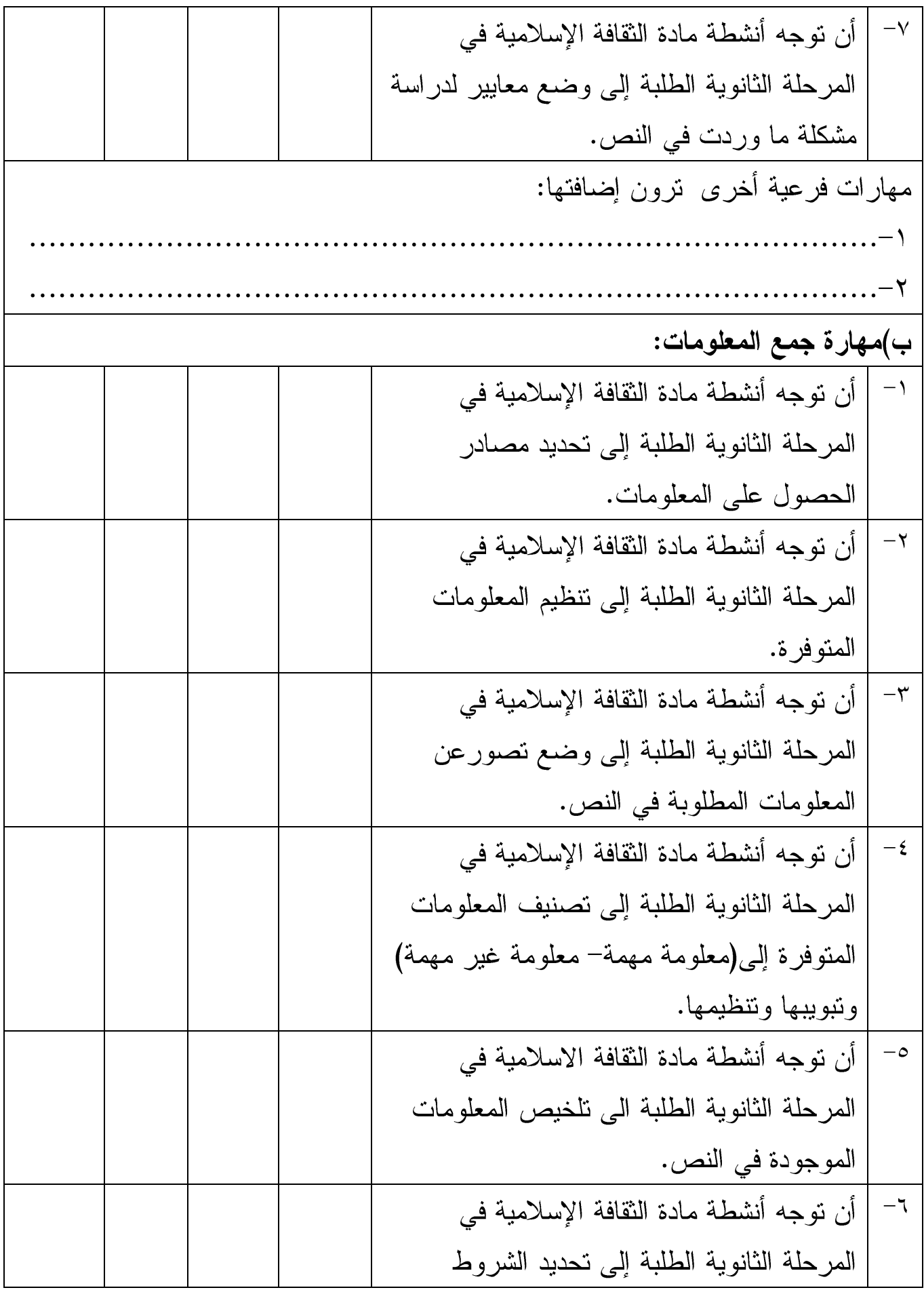




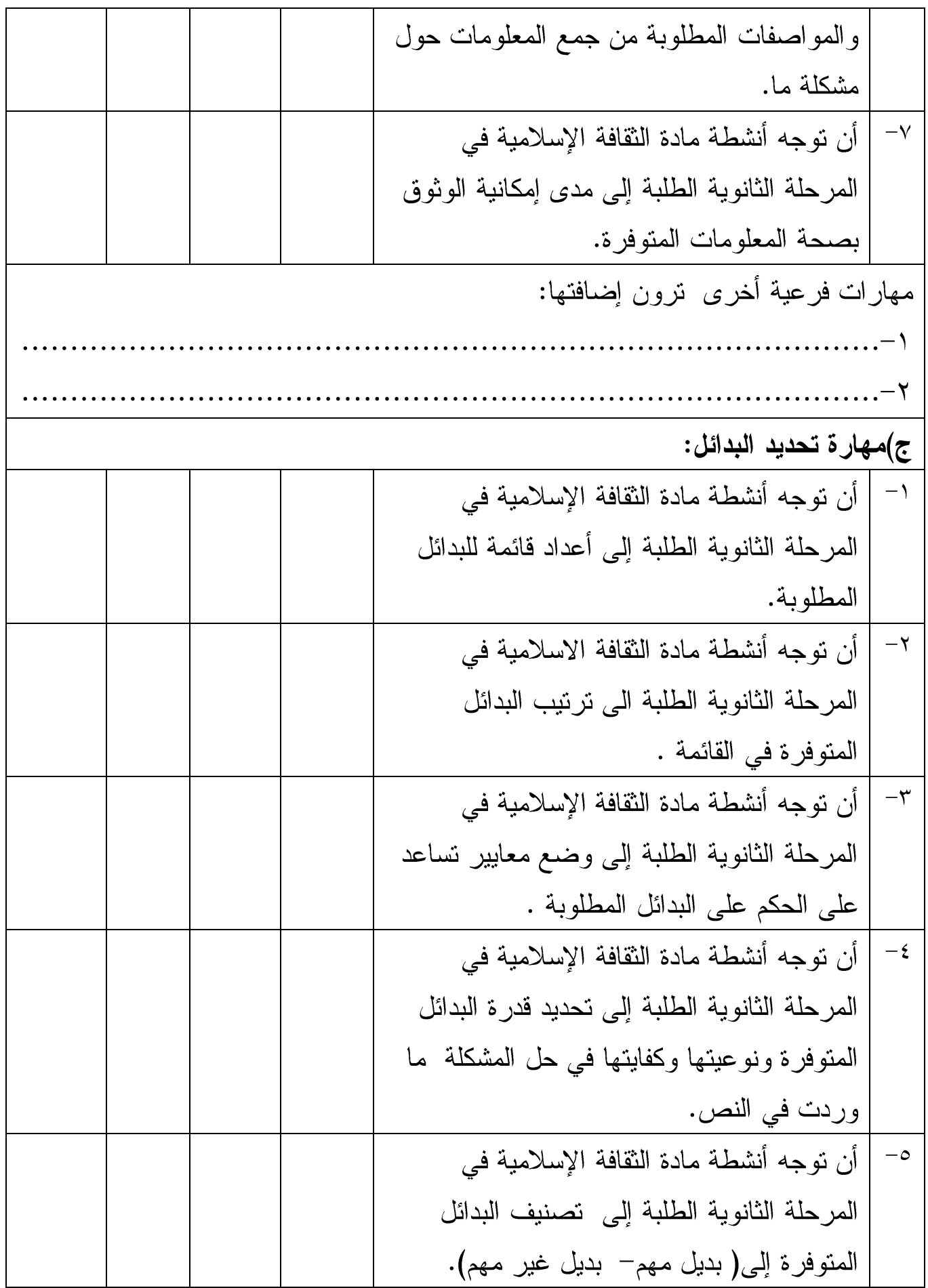




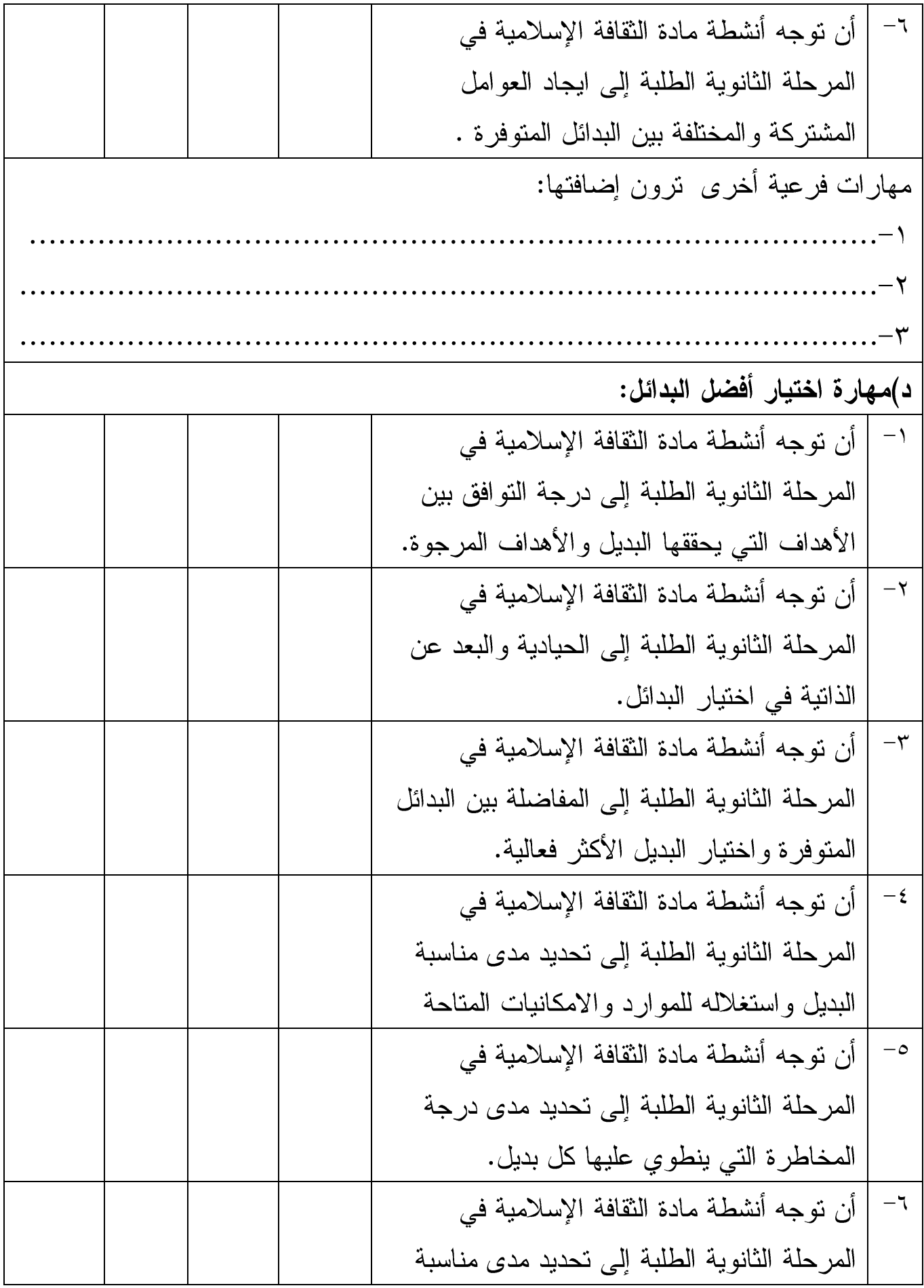




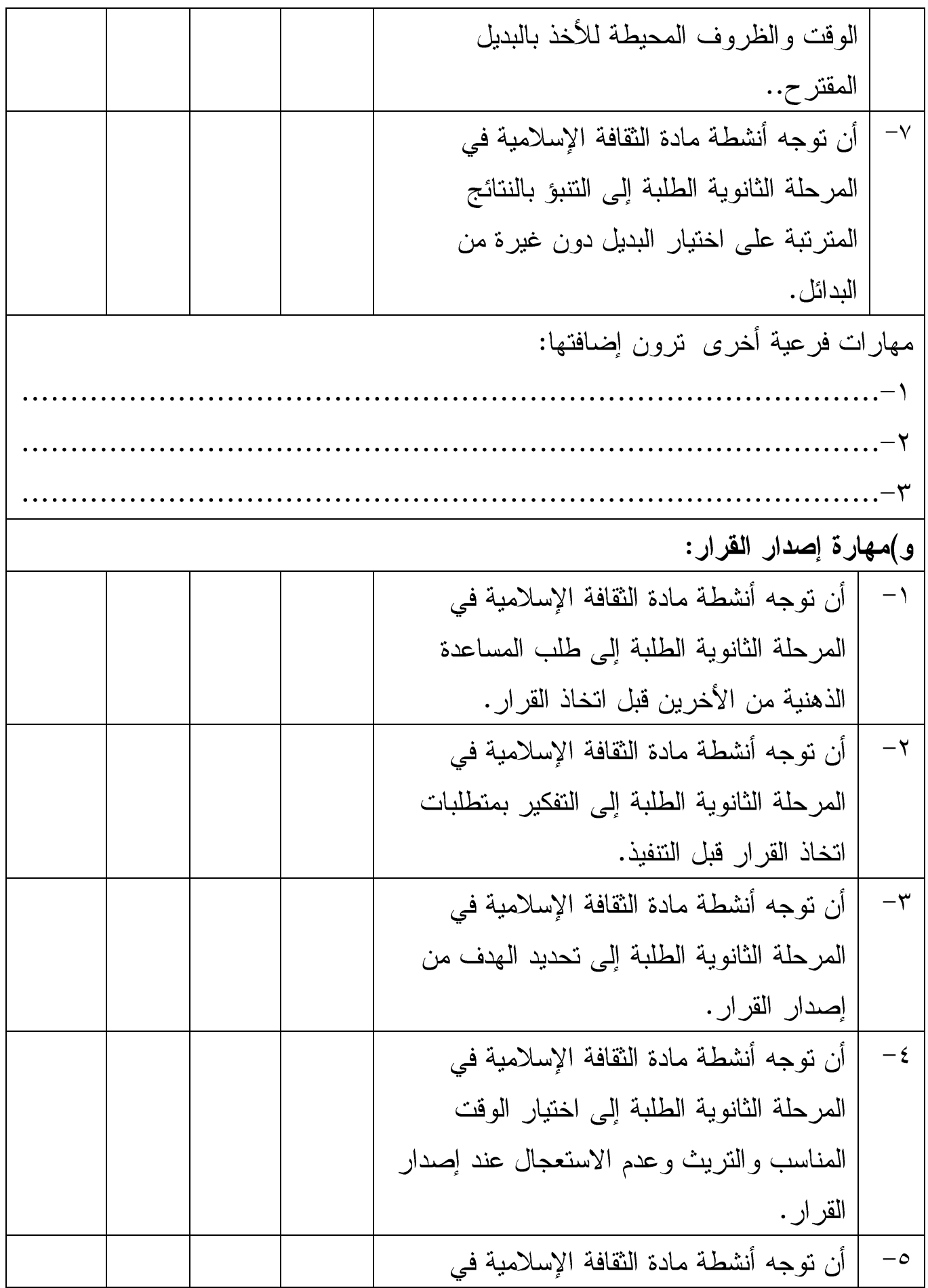




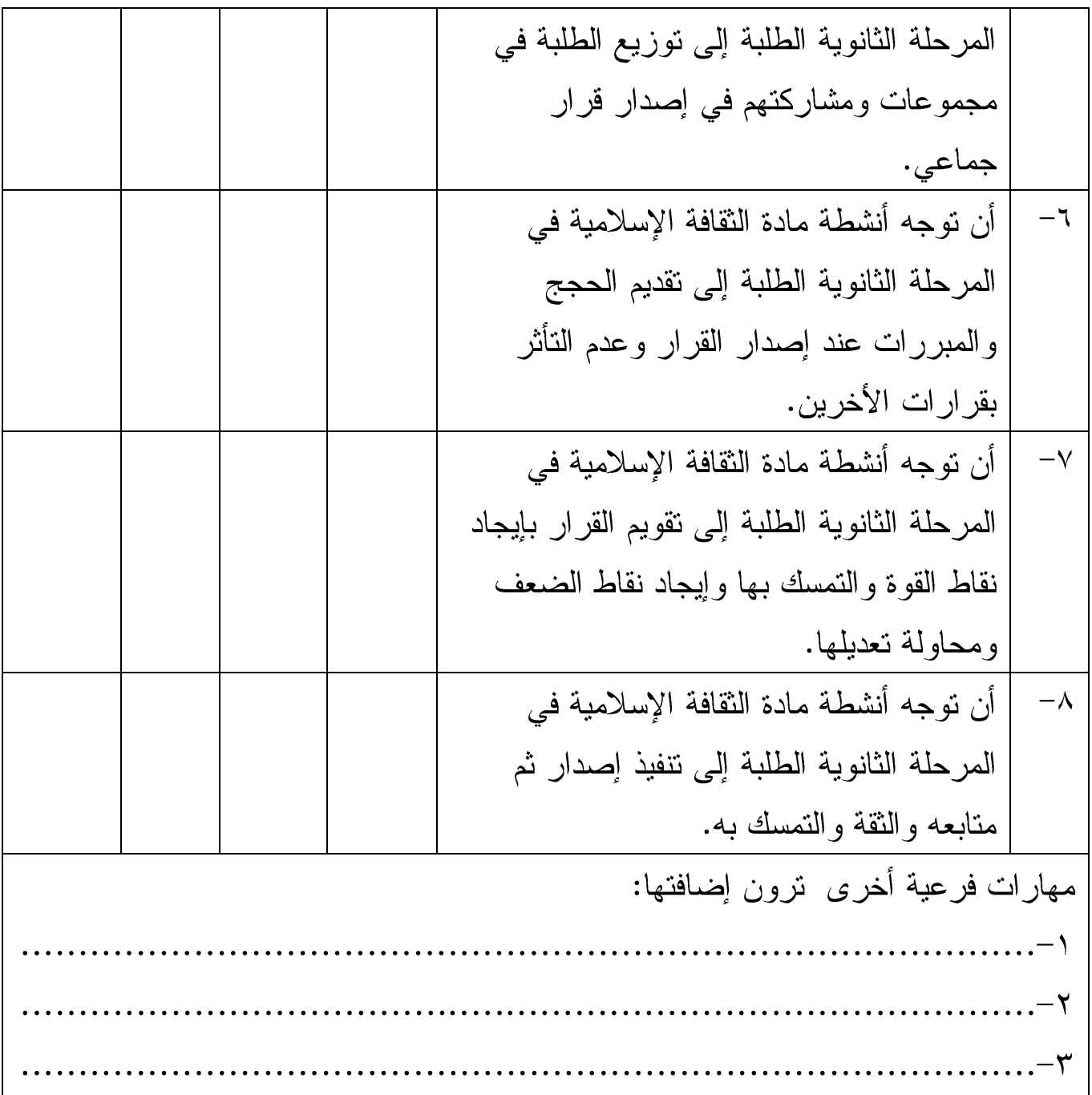




\section{الملحق رقم(ب)}

قائمة أسماء السادة المحكمين على أداة الدراسة

(قائمة مهار ات اتخاذ القرار)

أسماء السادة المحكمين على قائمة مهارات اتخاذ القرار

\begin{tabular}{|c|c|c|c|c|c|}
\hline جهة العمل & التخصص & الوظيفة & الدرجة العلمية & الاســـــــم & م \\
\hline طالأمعة آل البيت & و ألإسلامية العلوم & أستاذ & دكتور اه & أحمد الزعبي ألهيم & 1 \\
\hline وآلآدكلية العلوم & دراسات إسرامية & أستاذ & دكتور اه & أ. محمد شأمل رياض & $r$ \\
\hline 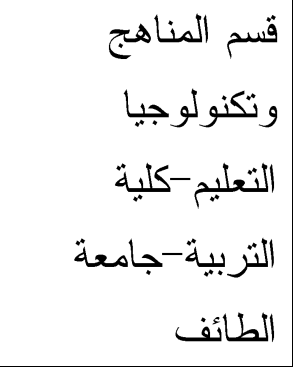 & تداهريج اللغة & أستاذ & دكتور اه & أ. أ. دم/ ناصر & $r$ \\
\hline جامعة أم القرى & الدريس اللغنة & أستاذ & دكتور اه & $\begin{array}{r}\text { أ. د/حنان } \\
\text { النمرحان عو اد } \\
\end{array}$ & $\varepsilon$ \\
\hline كلية التزبية الطائف-- & إلتداهي وطر ائق & مشارك & دكتور اه & |الغامدي & 0 \\
\hline كلية التزبية جامعة & تدريس العلوم & مشارك & دكتور اه & سليمان حمروش & 1 \\
\hline
\end{tabular}




\begin{tabular}{|c|c|c|c|c|c|}
\hline جامعة الطائف & وناهج & مشارك & دكتور اه & الجودي & V \\
\hline خالد -كلية التزبية الملك & تدريس (اللغة وطرق & مشارك & دكتور اه & أحمد إبر اهيم & $\Lambda$ \\
\hline جلية التزبية- & تكنولوجيا التعليم & مشارك & دكتور اه & عثـ الز هر اء محمود & 9 \\
\hline كلبة التزبية- & تزبية إسـاهية وأساليب & مساعد & دكتور اه & إسماعيل & 1. \\
\hline جامعة حائل & 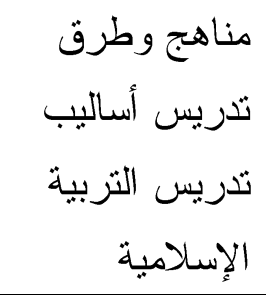 & مساعد & دكتور اه & سليم الخصاونـة خلمد أحمد & 11 \\
\hline خالدعة الملك & در اسات إسلامية & مساعد & دكتور اه & دم دمد سعدة عبدالله & ir \\
\hline خالدعاة الملكية التربية & در اسات إسلامية & مساعد & دكتور اه & د. ثـاضر اهيم عكاشة & r \\
\hline جامعة الدمام-كلية & المناهج العامة & مساعد & دكتور اه & د. ديوسف سعيد & $1 \varepsilon$ \\
\hline جامعة أم القرى & تدريس وطرق & مساعد & دكتور اه & دمد عبدالله عباس & 10 \\
\hline
\end{tabular}




\begin{tabular}{|c|c|c|c|c|c|}
\hline كلية التزبية الطائف- & تدريس العلوم وطر ائق & أستاذ & دكتور اه & الحمبد خضرة عبد & 17 \\
\hline كلية التزبية & تدريس العلوم وطر ائق & أستاذ & دكتور اه & دابو عاذرة سناء محمد & IV \\
\hline كلية التربية الطائف- & طرق تربية خاصة & أستاذ & دكتور اه & حلمي دمى محمد & 11 \\
\hline كلية التزبية الطائف- & تدريس طرق & أستاذ & دكتور اه & الحميد سليمان عبد & 19 \\
\hline كلية الملك عبدالله & وادارة تزبوية & أستاذ & دكثور اه & العامري دبداله محمد & $r$. \\
\hline كلية التربية الطائف-- & تكنولوجيا التعليم & مساعد & دكتور اه & زكي الزو ايدي أحمد & rI \\
\hline تعليم الرياض & تداهرج وطر ائق الإسلامبة & مثربوف متفرغ & دكتور اه & دم. ماجد سالم & YY \\
\hline جامعة أم القرى & تدريس العلوم وطرق & محاضر & ماجستير & دم. السيد محمد إبر اهيم & r \\
\hline خالد جلكة الملكة الثربية & تداهج وطر الإسلائق الدر اسات & محاضر & ماجستير & دحمد القحطانية بحيى & $r \varepsilon$ \\
\hline
\end{tabular}

